\title{
Generating Profits out of Passion: A Study of New Zealand Wineries
}

\author{
By \\ Juhie Navin Sugand \\ A thesis \\ submitted to Victoria University of Wellington \\ in partial fulfilment of the requirements of the degree of \\ Master of Management Studies
}

Victoria University of Wellington

2014 


\section{Acknowledgements}

To start my acknowledgements, I would like to offer profound thanks to my supervisor, Assoc. Prof. Urs Daellenbach. I am greatly indebted to you for your invaluable guidance, encouragement, patience, and immense wealth of knowledge which you graciously shared with me. The meetings were always intellectually stimulating, engaging and fun. I am deeply grateful for your prompt and rigorous feedback, and steadfast support throughout this thesis.

To my mum, dad and brother, without whom this thesis would not have been possible, I would like to thank you for giving me the opportunity to pursue my post-graduate studies. I extend my heartfelt appreciation for your love and unwavering support.

To Robert, thank you for always being there for me, proof-reading, keeping me motivated when times got tough, and working the Master's room night shift with me on more occasions than you probably wish to remember.

To all my friends, thanks for your encouragement and support.

To all academic and administrative staff at the School of Management, Victoria University of Wellington, for all your assistance with the various issues that cropped up during the course of completing this thesis I am very grateful.

Finally, to all those who participated in this study, for your time and co-operation. I feel very privileged to be able to get a glimpse into your worlds. 


\title{
Generating Profits out of Passion: A Study of New Zealand Wineries
}

\begin{abstract}
Lifestyle entrepreneurship is associated with entrepreneurs who operate businesses primarily for reasons associated with non-economic motives such as pursuit of passion, work-life balance, quality of life, and/or achieving other personal goals and objectives. Although non-economic motives are usually assumed to take precedence in such businesses, economic objectives are also important to lifestyle entrepreneurs, as they provide the means to sustain the business and support the lifestyle sought by the entrepreneur. This study aims to examine two key aspects of lifestyle entrepreneurship. Firstly, it investigates the challenges encountered by lifestyle entrepreneurs in their pursuit of economic and non-economic motivations simultaneously. And secondly, it looks at the strategies employed by lifestyle entrepreneurs to cope with those challenges.
\end{abstract}

Data for this study were collected qualitatively, through in-depth, semistructured interviews. A set of open ended questions were used to explore the perceptions and experiences of entrepreneurs. All interviews were conducted face-toface and were averaged 60 minutes in duration. The sample comprised of 14 lifestyle entrepreneurs from the wine industry of New Zealand, a sector which has been associated with lifestyle entrepreneurship in previous literature. The participants were purposefully selected from three wine regions, namely Nelson, Martinborough and Waiheke Island, to add to the generalizability of the findings depending on whether regional differences were apparent.

This study indicates that the main challenges encountered by the selected sample were issues pertaining to simultaneously growing the business, as well as their ability to achieve or maintain desired work-life balance. The strategies adopted by the respondents to cope with these challenges included maintaining their business smallscale, diversification of the business operations, addressing seasonality in business operations, personal engagement with the customers, delegating responsibility and reprioritizing economic over non-economic objectives. More specifically, the respondents' activities covered a range of business operations including grape growing, winemaking, domestic wine sales, international wine exports, cellar-door sales, 
providing accommodation on the vineyard (holiday house), and restaurant/cafe facilities. All wineries had achieved some form of growth over time, but most of them still remained small-scale. This was mainly due to reasons such as the desire to retain control and hands-on involvement. For a few wineries, the lifestyle orientation had changed over the course of time. Even though maintaining lifestyle objectives were still important to them, economic motivations now took precedence in their business. This was mainly due to factors such as having stimulated significant growth, changing market environment, increase in competition, or the need to ensure the viability of the business. 


\section{Table of Contents}

Acknowledgements ......................................................................................................... ii

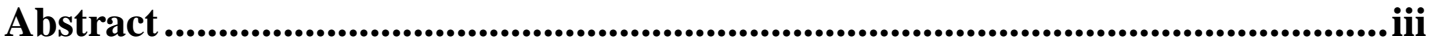

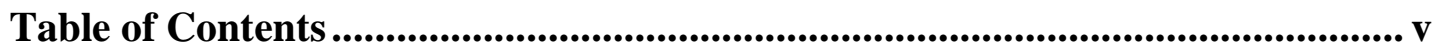

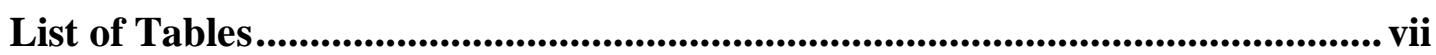

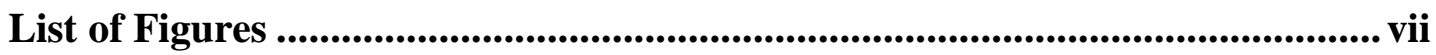

Chapter 1: Introduction ............................................................................................ 1

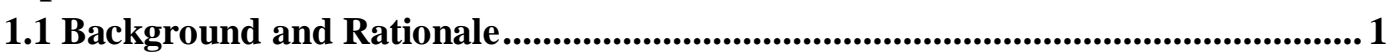

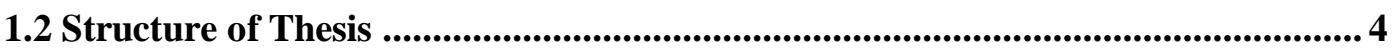

Chapter 2: Literature Review .........................................................................5

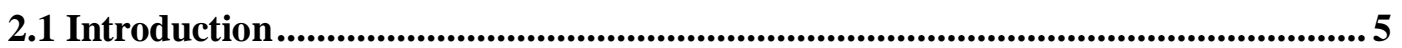

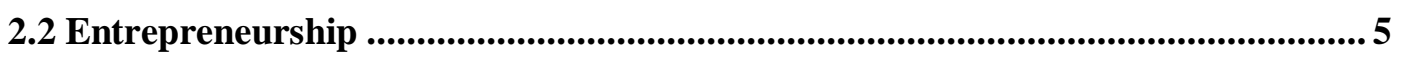

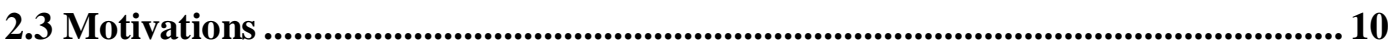

2.4 Lifestyle entrepreneurship ........................................................................................... 12

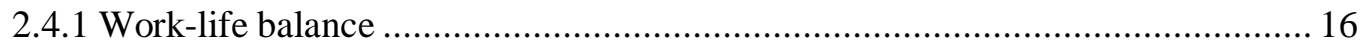

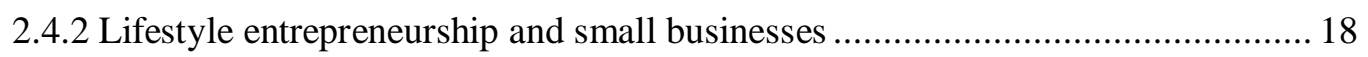

2.4.3 Lifestyle entrepreneurship and family businesses ............................................ 19

2.5 Business growth ................................................................................................................... 20

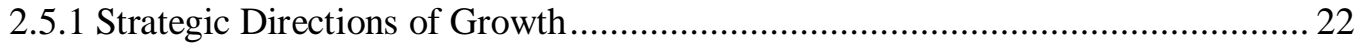

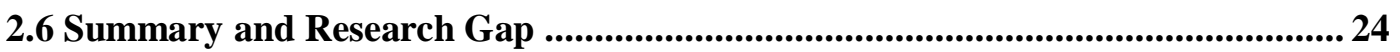

Chapter 3: Methodology .............................................................................. 26

3.1 Introduction ........................................................................................................................ 26

3.2 Research Questions...................................................................................................... 26

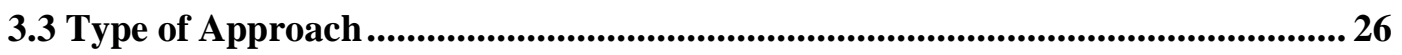

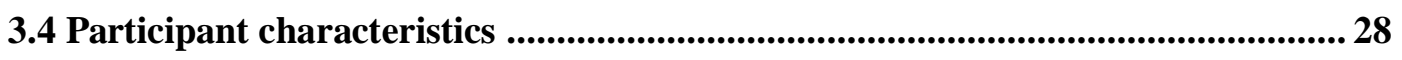

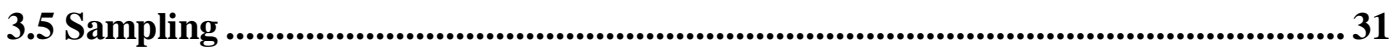

3.6 The Research Context ............................................................................................................... 33

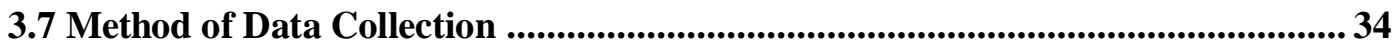

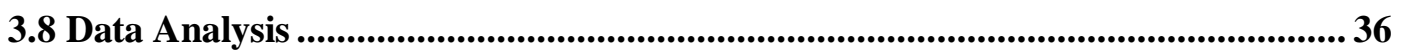

3.9 Ethical Consideration .................................................................................... 37

3.10 Challenges and Limitations ....................................................................................... 37

3.11 Summary ............................................................................................................................ 38

Chapter 4: Findings ..................................................................................................... 40

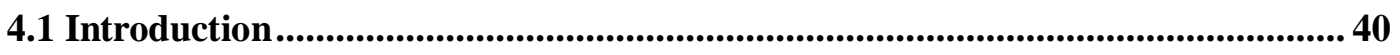

4.2 Profile of Participants...................................................................................................... 40

4.3 Motivations, Goals and Objectives...................................................................................... 44

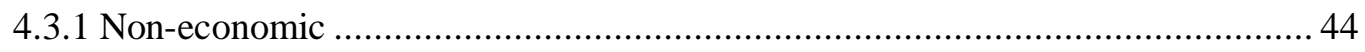

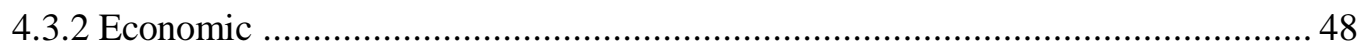

4.4 Challenges encountered by lifestyle entrepreneurs ........................................... 49

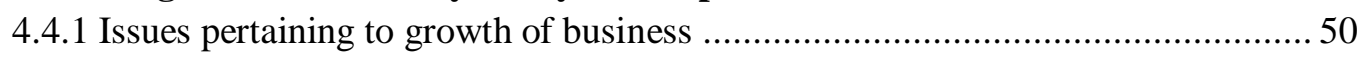

4.4.2 Issues pertaining to achieving desired work-life balance................................. 56

4.5 Strategies employed to cope with the challenges ...............................................6 61 


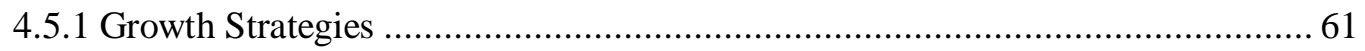

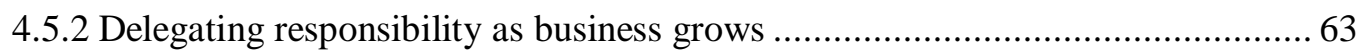

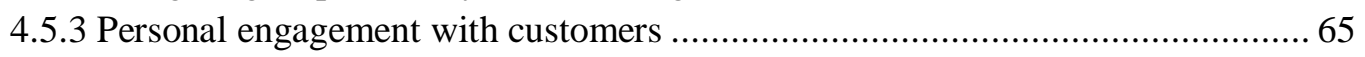

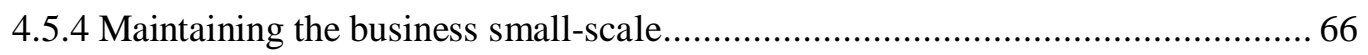

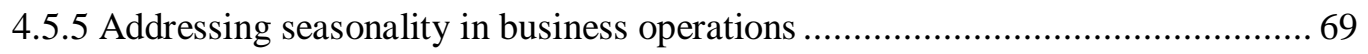

4.5.6 Prioritizing economic over non-economic objectives ........................................ 70

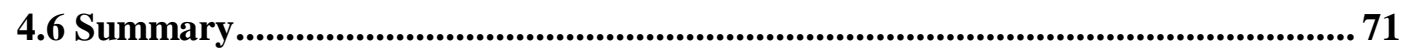

Chapter 5: Discussion ........................................................................................ 72

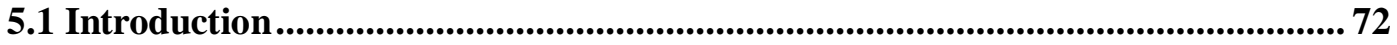

5.2 Motivations and Economic Viability ........................................................................ 72

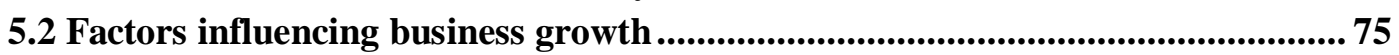

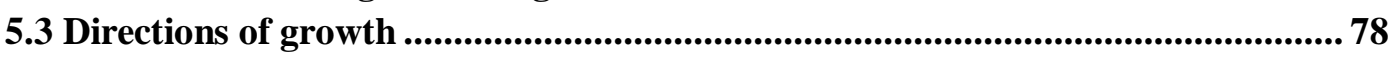

5.4 Business Growth and Lifestyle Orientation............................................................ 80

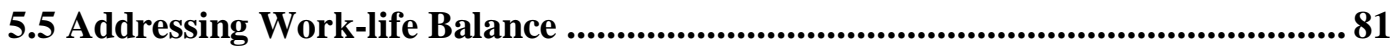

5.6 Summary ........................................................................................................................................ 84

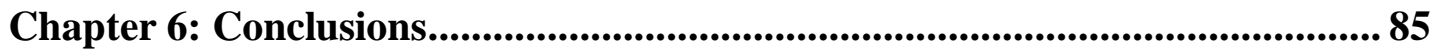

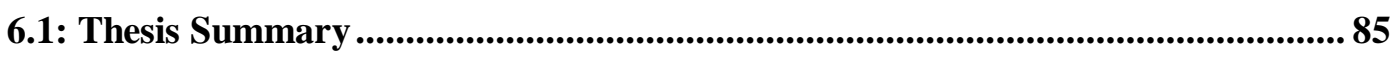

6.2 Avenues for Future Research ........................................................................................... 87

6.3 Limitations ............................................................................................................................. 88

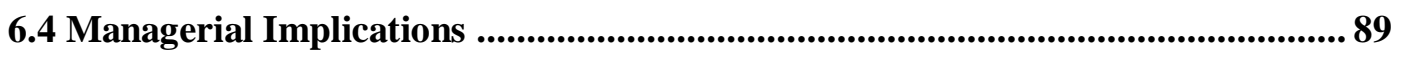

6.5 Concluding Statement .............................................................................. 90

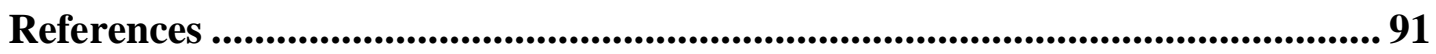

Appendix A: Information Sheet ................................................................. 106

Appendix B: Research Consent Form .................................................................. 107

Appendix C: Interview Outline .................................................................... 108 


\section{List of Tables}

Table 1: Definition of the term 'entrepreneur' ................................................................ 6

Table 2: Definitions of the term 'entrepreneurship' .......................................................

Table 3: Small Business Pro-growth and Inhibiting Growth Factors .............................. 20

Table 4: Wineries indicating lifestyle orientation ................................................................. 29

Table 5: Summary of Participant's Profile .................................................................. 41

List of Figures

Figure 1: Growth Vector Components.............................................................23 


\section{Chapter 1: Introduction}

\subsection{Background and Rationale}

In the course of my search for a good research topic, several ideas came to mind. However, the integration of personal passion and business ambitions struck me as a particularly interesting notion, and seemed to be a significant and growing trend in contemporary business. Quite recently, I encountered this notion personally during my travels in New Zealand as an international student. In the course of these travels over the past 3 years, I visited a number of boutique businesses including sheep rearing farms, chocolate factories, breweries, cheese-making businesses, wineries, and various tourism-related companies (rafting, bungee-jumping, kayaking, skydiving and sailing). During many of these visits I had the opportunity to talk to the ownermanagers of these firms. Amidst these conversations, my curiosity would often lead me to ask them the question: what got you interested in setting up this business? In several of these interactions, the owner-managers would suggest that they had established the business for reasons such as desire for the perceived lifestyle, passion for the product/service, desire to live in the chosen location, etc. Generally, the aspects of the business the owner-managers most enjoyed included flexible working hours, hands-on involvement in the business, involvement of family in business, and personal engagement with the customers.

Later, having reviewed existing research on different types of businesses in academic journal articles and books, I encountered the concept of 'lifestyle entrepreneurship'. Lifestyle entrepreneurship can be described as a type of business run by an individual to facilitate a desired lifestyle (Bridge, O'Neill, \& Cromie, 2003) and lifestyle entrepreneurs are known to set up business activities around preferred lifestyle and personal goals (Kaplan, 2003; Kaplan \& Warren, 2007). Lifestyle entrepreneurs commonly establish businesses for reasons associated with lifestyle such as pursuit of passion, desire for work-life balance and quality of life.

Over the past few decades, the phenomenon of entrepreneurship has generated considerable interest from both academics and practitioners alike. "Throughout intellectual history, the entrepreneur has worn many faces and fulfilled many roles" 
(Wennekers \& Thurik, 1999, p. 30) These entrepreneurial roles generally include being an innovator, a decision-maker, an individual who assumes risks associated with uncertainty, the owner of an enterprise - to name a few. Narula (2011) describes the process of entrepreneurship using "trees" as a metaphor. The author illustrates that launching or growing a business is like nurturing a tree. It starts small, with a seed (i.e., a thought, an idea), which slowly takes root. When all the conditions are right, a stem (i.e., product/service) emerges and leaves (i.e., clients) begin to form. At first, the sapling is very fragile. The growth (i.e., momentum of business) can easily be crushed by a host of factors including, insufficient water or sunlight (i.e., lack of funding), weeds and crowded roots (i.e., competition), or infertile soil (i.e., bad market conditions). It is crucial to weed and fence (i.e., stay focused), and protect your tree from mowers (i.e., cynics) and wildlife (i.e., other distractions). If one seeks open spaces (i.e., desirable and unique products), and benefits from healthy soil (i.e., favorable conditions), the tree (i.e., business) is likely to take root, grow and flourish. As can be seen from this analogy, the process of entrepreneurship is dynamic in nature and entrepreneurs are likely to face numerous challenges in the course of running their businesses.

Entrepreneurship plays a significant role in the process of economic growth and development of the global economy (Baumol, 1968). The importance of entrepreneurship is noted from both a micro- and macro-economic perspective. Entrepreneurs are valuable at both the local and national levels of the economies (Henderson, 2002). At the national level, countries with higher entrepreneurial activity usually have stronger GDP growth. Entrepreneurs create new investments and new businesses; which may lead to the creation of new jobs, intensification of competition and may increase productivity by introducing new technologies or working practices (Kidd, 2008). Typically, an increase in the number of entrepreneurs leads to an increase in the economic growth. Like many other countries, entrepreneurship plays a key role in the economic development of New Zealand. In 2003, New Zealand was ranked as the most entrepreneurial country amongst the OECD countries (almost one in seven adults classified as entrepreneurs); reflecting the highest number of individuals engaged in the start-up of an enterprise (Frederick, 2004). The characteristic feature of enterprises in New Zealand is that a majority of them tend to be small in size (have fewer than 20 employees). A survey conducted by Statistics 
New Zealand in 2012, highlighted that $97.2 \%$ of all New Zealand enterprises were small-scale (Statistics New Zealand, 2012). Taken as a whole, these small enterprises make an important contribution to the New Zealand economy. While such statistics are illuminating about the prevalence and importance of entrepreneurship, these data shed little light on whether lifestyle entrepreneurs face similar or different challenges as compared to the classical profit and growth-seeking entrepreneurs studied extensively in the literature.

For lifestyle entrepreneurs, the concept of entrepreneurship goes beyond solely economic objectives; incorporating social and cultural values (Dawson, Joanna, \& Cohen 2011). Lifestyle businesses are argued to be closely aligned with the entrepreneurs' personal values, interests, and passions (Marcketti, Niehm, \& Fuloria 2006). As suggested by Sisson (n.d., para. 1), "if you love what you do, you'll never work another day in your life". The notion of "passion" comes across strongly in the lifestyle entrepreneurship literature.

Entrepreneurial motivation also plays a key role in shaping the business. Noneconomic motivations usually take precedence in lifestyle business operations. However, along with non-economic objectives, economic objectives are also important to lifestyle entrepreneurs as they provide the means to sustain and support the lifestyle of the entrepreneur. Making a profit is usually what enables a business to accomplish its other goals and objectives. Even if the business is succeeding at other measures (achieving non-economic objectives), if it is failing to financially break-even or generate profits to allow reinvestment or regeneration, then the continuous losses may threaten the long-term viability of the business. It can also be argued that if a business is not pursuing a profit, it is not a business, it is merely a hobby. The business might not need to be making huge profits, but it may be essential to get some return on investment in order to ensure the smooth functioning of business.

Some researchers suggest that lifestyle businesses lack growth-orientation (e.g., Peters, Frehse, \& Buhalis 2009). In such cases, lifestyle entrepreneurs are viewed to deliberately sacrifice growth in order to maintain lifestyle choices (Henderson, 2002). This could be due to factors such as a desire to retain control, to maintain personal touch, or autonomy. Lifestyle entrepreneurs like to be involved in all spheres of the business. However, in some cases, in order to ensure survival and viability of business, 
the firms may need to grow and develop their businesses. This, then, poses a potential challenge for lifestyle entrepreneurs.

The above mentioned factors highlight the issue of having to balance economic and non-economic motives simultaneously in order to achieve desired personal and business goals and objectives. Despite research on lifestyle entrepreneurship having gained momentum in the past two decades, the issues relating to simultaneously pursuing economic and non-economic motives do not appear to have not been addressed comprehensively in existing research. This study aims to shed light on the these issues by, firstly, investigating the challenges encountered by lifestyle entrepreneurs in their pursuit of economic and non-economic motives simultaneously and secondly, by exploring the strategies deployed by these entrepreneurs to cope with these challenges.

\subsection{Structure of Thesis}

The overall structure of this study takes the form of six chapters (which includes this introductory chapter). Chapter 2 reviews existing research across various domains relevant to lifestyle entrepreneurship and highlights the main research gaps, setting the rationales for this study. Following this, Chapter 3 addresses the methodology used for this study. This chapter outlines the central research questions and discusses the research design employed in this study including the type of approach used, sampling, methods of data collection and analysis, and ethical considerations. Chapter 4 presents the findings from this research process. The analysis and discussion of these findings takes place in Chapter 5. Relevant references to the literature are made throughout the discussion. Finally, the conclusions of this study are drawn in Chapter 6. 


\section{Chapter 2: Literature Review}

\subsection{Introduction}

This chapter reviews the literature related to lifestyle entrepreneurship. The chapter starts by describing entrepreneurship. This is followed by an investigation of various motivations underlying the formation of business enterprises. The subsequent section discusses the phenomenon of lifestyle entrepreneurship and the various aspects associated with it. Finally, the gaps in literature which provide the direction and rationale for the present study are discussed.

\subsection{Entrepreneurship}

"Entrepreneurship is a multifaceted phenomenon that cuts across many disciplinary boundaries" (Low \& MacMillan, 1988, p.140). Thus, it has been an ongoing challenge for academics to select an appropriate basis for understanding and defining the entrepreneurial person (Cunningham \& Lischeron, 1991). Even with the extensive literature on this topic, some authors note that, there is still no universally accepted definition of either an "entrepreneur" or "entrepreneurship" (Gartner, 1990; Low, 2001; Low \& MacMillan, 1988; Ucbasaran, Westhead, \& Wright 2001).

Defining these terms is certainly not an easy task. It is possible to find almost as many definitions as there are researchers in this field perhaps because the entrepreneurship literature draws from a broad array of disciplinary backgrounds including economics, psychology, sociology, anthropology, marketing, management (Bull \& Willard, 1993; Hebert \& Link, 1989; Kalantaridis \& Bika, 2006). Each of these disciplines employs different metatheories, addresses different research questions and focuses on different levels of analysis (Martinelli, 1994; Thornton, 1999). For example, Austrian economist Joseph Schumpeter's definition of entrepreneurship places emphasis on wealth creation through innovation. He defines an entrepreneur as an individual who carries out "new combinations" of business organization, methods of production, sources of raw material, products or services, market segment, or forms of organization (Schumpeter, 1934). 
The psychology literature, on the other hand, focuses on personality factors, and considers that the most distinctive features of entrepreneurs are their attitudes and values toward work and life (Cunningham \& Lischeron, 1991; Puri \& Robinson, 2013; Zhao \& Seibert, 2006). It has been argued that the business approach of entrepreneurs is primarily influenced by personal needs, attitudes, drives, beliefs, and values (Cunningham \& Lischeron, 1991). Personality characteristics such as personal values (Conger, 2012), risk-taking propensity (Macko \& Tyszka, 2009), passion for work (Murnieks, Mosakowski, \& Cardon 2012), and need for achievement (McClelland, 1961) have also received considerable attention in research pertaining to entrepreneurship. Hills and La forge (1992) identified an interface between marketing and entrepreneurship, with Collinson and Shaw (2001) suggesting that the three key areas of interface include focus on change, opportunistic nature, and innovative approach to management.

The following tables present various definitions of the terms 'entrepreneur' and 'entrepreneurship':

Table 1: Definition of the term 'entrepreneur'

\begin{tabular}{|l|l|}
\hline Author(s) & Entrepreneur is defined as .... \\
\hline $\begin{array}{l}\text { Schumpeter (1947, p. } \\
\text { 151) }\end{array}$ & $\begin{array}{l}\text { someone who is responsible for "the doing of new } \\
\text { things or the doing of things that are already being done } \\
\text { in a new way" }\end{array}$ \\
\hline Casson (1982, p. 23) & $\begin{array}{l}\text { "someone who specializes in taking judgemental } \\
\text { decisions about the coordination of scarce resources" }\end{array}$ \\
\hline $\begin{array}{l}\text { Herbert and Link (1988, } 155) \\
\text { "someone who specializes in taking responsibility for } \\
\text { and making judgemental decisions that affect the } \\
\text { location, the form, and the use of goods, resources or } \\
\text { institutions" }\end{array}$ \\
\hline $\begin{array}{l}\text { Bygrave and Hofer } \\
\text { "someone who perceives an opportunity and creates an } \\
\text { organization to pursue it" }\end{array}$ \\
\hline $\begin{array}{l}\text { Gray (2002, p. 62) } \\
\text { "individuals who manage a business with the intention } \\
\text { of expanding that business and with the leadership and } \\
\text { managerial capabilities for achieving their goals, } \\
\text { generally in the face of strong competition from other } \\
\text { firms, large and small" }\end{array}$ \\
\hline $\begin{array}{l}\text { Zhao and Seibert (2006, } \\
\text { p. 263) }\end{array}$ & $\begin{array}{l}\text { "someone who is the founder, owner, and manager of a } \\
\text { small business and whose principal purpose is growth" }\end{array}$ \\
\hline
\end{tabular}


Table 2: Definitions of the term 'entrepreneurship'

\begin{tabular}{|c|c|}
\hline Author(s) & Entrepreneurship is defined as ... \\
\hline $\begin{array}{l}\text { (Low and MacMillan, } \\
\text { 1988, p.141) }\end{array}$ & "creation of new enterprise" \\
\hline $\begin{array}{l}\text { Bygrave and Hofer } \\
(1991, \text { p. 14) }\end{array}$ & $\begin{array}{l}\text { "involves all the functions, activities, and actions } \\
\text { associated with the perceiving of opportunities and the } \\
\text { creation of organizations to pursue them" }\end{array}$ \\
\hline $\begin{array}{l}\text { Shane and Venkat- } \\
\operatorname{araman}(2000, \text { p.218) }\end{array}$ & $\begin{array}{l}\text { "opportunities to create future goods and services are } \\
\text { discovered, evaluated, and exploited" }\end{array}$ \\
\hline $\begin{array}{l}\text { Hitt, Ireland, Camp, and } \\
\text { Sexton (2001, p. 480) }\end{array}$ & $\begin{array}{l}\text { "the identification and exploitation of previously } \\
\text { unexploited opportunities" }\end{array}$ \\
\hline $\begin{array}{l}\text { Ireland, Hitt, Camp and } \\
\text { Sexton (2001, p. 51) }\end{array}$ & $\begin{array}{l}\text { "a context-dependent social process through which } \\
\text { individuals and teams create wealth by bringing } \\
\text { together unique packages of resources to exploit } \\
\text { marketplace opportunities" }\end{array}$ \\
\hline $\begin{array}{l}\text { Eckhardt and Shane } \\
(2003, \text { p. } 336)\end{array}$ & $\begin{array}{l}\text { the "discovery, evaluation, and exploitation of future } \\
\text { goods and services" }\end{array}$ \\
\hline $\begin{array}{l}\text { Timmons and Spinelli } \\
(2004, \text { p. 47) }\end{array}$ & $\begin{array}{l}\text { "is a way of thinking, reasoning, and acting that is } \\
\text { opportunity obsessed, holistic in approach, and } \\
\text { leadership balanced" }\end{array}$ \\
\hline $\begin{array}{l}\text { Kaplan and Warren } \\
(2007, \text { p. 14) }\end{array}$ & $\begin{array}{l}\text { "the process of creating something different by } \\
\text { devoting the necessary time and effort; assuming the } \\
\text { accompanying financial, psychic, and social risks; and } \\
\text { receiving the resulting monetary rewards and personal } \\
\text { satisfaction"" }\end{array}$ \\
\hline $\begin{array}{l}\text { Klapper, Amit, and } \\
\text { Guillen }(2010 \text {, p. 131) }\end{array}$ & $\begin{array}{l}\text { "the activities of an individual or a group aimed at } \\
\text { initiating economic activities in the formal sector under } \\
\text { a legal form of business" }\end{array}$ \\
\hline Kuratko (2012, p. 5) & $\begin{array}{l}\text { "a dynamic process of vision, change, and creation. It } \\
\text { requires an application of energy and passion toward } \\
\text { the creation and implementation of new ideas and } \\
\text { creative solutions. Essential ingredients include the } \\
\text { willingness to take calculated risks-in terms of time, } \\
\text { equity, or career; the ability to formulate an effective } \\
\text { venture team; the creative skill to marshal needed } \\
\text { resources; the fundamental skill of building a solid } \\
\text { business plan; and, finally, the vision to recognize } \\
\text { opportunity where others see chaos, contradiction, and } \\
\text { confusion" }\end{array}$ \\
\hline
\end{tabular}


As can be seen from this sample of definitions, the process of entrepreneurship is complex and dynamic in nature. The different dimensions of entrepreneurship that authors have focused on include dispositions, behaviour and outcomes. The definitions in the above table also differ in whether purpose, innovation, risk-taking propensity or growth are essential criteria for an individual to qualify as an entrepreneur. The process of entrepreneurship is also influenced by the attributes of the entrepreneurs' leadership capabilities and management skills.

It is also apparent that the conceptual meaning of entrepreneurship has shifted over time. The dominant meaning of entrepreneurship has historically been related to economic theories (Ogbor, 2000). However, in recent years, entrepreneurship has come to encompass and reflect greater social and cultural dimensions. For example, it has been argued that entrepreneurship is as much a cultural identity as it is a business philosophy, encompassing a number of non-pecuniary benefits, such as "being your own boss" (Hamilton, 2000). In general, it is apparent that entrepreneurial activity and the social meaning ascribed to the entrepreneur are influenced by numerous factors, including economic, social, political, cultural, and geographical factors (Reynolds, Carter, Gartner, \& Greene, 2004; Stam, 2007).

Entrepreneurs are often associated with being highly innovative. Innovation can be described as doing something new, which could be based on a new idea, product, service, technology or market. The capacity of innovation implies that the entrepreneur has a desire for seeking new solutions and new ways of action. Kaplan and Warren (2007), though, suggest that "entrepreneurs do not have to be innovative to be successful, but they have to understand and manage the innovation process within their companies" (p.19). In other words, entrepreneurs do not necessarily have to be the source of innovation themselves; they could exploit the innovation developed elsewhere, particularly via an emphasis on business growth (as noted by Gray, 2002).

Entrepreneurship research has also focused on how entrepreneurs come to acquire or form business. Entrepreneurship is heterogeneous in nature, and includes the creation of new businesses (Low \& MacMillan, 1988), the purchase of established business (Cooper \& Dunkelberg, 1986; Shane \& Venkataraman, 2000), and business inheritance (Chaganti \& Schneer, 1994; Cooper \& Dunkelberg, 1986). Based on this, 
there seems to no necessity to restrict entrepreneurship to those businesses founded by the entrepreneur.

As can be seen from Kuratko's (2012) definition (Table 2), passion can play an important role in the process of entrepreneurship. The significance of passion in entrepreneurship has also been noted by many other authors (Cardon, Zietsma, Saparito, Matherne, \& Davis, 2005; Laaksonen, Ainamo, Karjalainen, 2011; Smilor, 1997). As suggested by Cardon et al. (2009), "passion is deeply embedded in the folklore and practice of entrepreneurship" (p. 511). Passion can be defined as "a strong inclination toward an activity that people like, that they find important, and in which they invest time and energy" (Vallerand et al., 2003, p. 757). Entrepreneurial passion has been associated with love for their work (Shane, Locke, \& Collins, 2003), and enthusiasm or zeal for venture-related activities (Smilor, 1997). Cardon et al. (2009) argue that "passion is not aroused because some entrepreneurs are inherently disposed to such feelings but, rather, because they are engaged in something that relates to a meaningful and salient self-identity for them" (p. 516). Smilor (1997) indicates that "passion emerges when one has the freedom and opportunity to pursue one's dream" (p. 342).

Overall, people embark on the journey of entrepreneurship for various reasons. Thus, it seems important to take into account the significant diversity in the entrepreneurial goals and motivations. Many people prefer the challenge that comes with being an entrepreneur, one who is self-employed and who establishes, organizes, manages, and assumes responsibility for a business, as opposed to working for someone else (Segal, Borgia, \& Schoenfeld, 2005). It has been argued that in addition to satisfying economic goals, the entrepreneurs also seek to satisfy personal and social goals (Dawson, Joanna, \& Cohen, 2011; Getz, Carlsen, \& Morrison, 2004). Different types of motivations underlying entrepreneurial activity are likely have an influence on the entrepreneurial process (Shane et al., 2003; Walker \& Brown, 2004). The manner in which entrepreneurs run their business depends partially on the reasons for establishing the business. For example, if the entrepreneur has established the business to maximize personal wealth, he/she will direct their available resources to achieve that goal. Entrepreneurial motivation is also likely to have an impact on the entrepreneur's decision-making process, strategies employed to achieve business goals, their attitude towards growth and development, etc. 
Based on this initial review of the literature, the present study includes the following key elements which are commonly agreed to give entrepreneurship its distinctive character:

a) Running a business: this covers creation of a new business, purchase of an established business and business inheritance;

b) Innovation: doing something new, which could be based on a new idea, product, service, technology or market;

c) Personal goals and motivations: Factors that drive individuals into entrepreneurship;

The next section investigates the diverse factors that motivate entrepreneurs.

\subsection{Motivations}

Many people dream of "being one's own boss" by establishing a business, but only a few realize this dream (Timmons, 1992; Wu, Matthews, \& Dagher, 2007). As noted in the section above, motivation plays a crucial role in the process of entrepreneurship. Entrepreneurial behaviour is significantly influenced by the individual's motivation to run the business (Carsrud \& Brannback, 2011). Entrepreneurs may be necessity-driven or opportunity-driven. Necessity-driven entrepreneurs are defined as "those who are pushed into starting businesses because they have no other work options and need a source of income" (Xavier, Kelley, Kew, Herrington, \& Vorderwulbecke, 2012, p. 8). On the other hand, opportunity driven entrepreneurs can be described as those who enter the entrepreneurial activity primarily to pursue an opportunity that they perceive (Xavier et al., 2012). Thus, opportunistic entrepreneurs choose to pursue entrepreneurship despite the existence of other attractive employment options (Carsrud \& Brannback, 2011). GEM (2005) categorized $83 \%$ of New Zealand entrepreneurs as being opportunistic, with only 1 in 12 New Zealand entrepreneurs being necessity-driven.

The existing literature suggests that the motivations for entrepreneurs to go into business ownership encompass both economic and non-economic factors (Cromie, 1987). The economic factors associated with entrepreneurship include financial profits, wealth creation and economic growth (Luke, Verreynne, \& Kearins 2007). The 
prospect of maximizing personal wealth appears to be the main motivating factor for many entrepreneurs. For example, entrepreneurship might provide individuals with the opportunity to satisfy their present and future financial requirements or goals (Chaudhuri, Datta, \& Ghosh, 2012). A number of entrepreneurs pursue steady growth and development of business. Such growth of the business may lead to an increase in market share, and increase in revenue.

In addition to economic motives, the entrepreneurs may also be driven by various non-economic motivations. Generally, the non-economic motivations include factors such as desire for independence, personal satisfaction, flexibility, control over business, recognition and need for achievement (Shane et al., 2003). A desire to achieve work-life balance can be another factor driving entrepreneurs; with factors such as child-rearing responsibilities (Still \& Walker, 2006) and obligation of caring for family members (Mattis, 2004) seen to influence some women to start their own business, since it allows greater flexibility, control and freedom in managing the different responsibilities (Rehman \& Roomi, 2012). These non-economic entrepreneurial motives are highlighted in a variety of studies (Cooper \& Artz, 1995; Morrison, Baum, \& Andrew, 2001; Morrison, Rimmington, \& Williams, 1999).

Jennings and Beaver (1997) point out that for some entrepreneurs the desire for responsibility, personal involvement and quality of life fashioned through owning their own business surpasses the pursuit of personal financial success. Walker and Brown (2004) found that non-financial criteria including personal satisfaction, pride in job, achievement and flexible lifestyle were generally valued higher than wealth creation. In addition, Dewhurst and Horobin (1998) examined small tourism enterprises in Yorkshire and found that the owners were twice as likely identify noneconomic motivations, in favour of economic ones, as reasons for starting their own businesses. Similarly, Thomas, Friel, Jameson, and Parsons (1997) conducted a survey of 1300 small tourism enterprises across the U.K. and discovered that nearly $80 \%$ of the owners gave prominence to non-economic motives. Likewise, Maritz and Beaver (2006) conducted a survey of 167 entrepreneurs in New Zealand and found that only $28 \%$ of entrepreneurs rated the desire to increase their personal wealth as their primary motive for establishing a business, with the remaining entrepreneurs rating their preference for other non-economic factors. 
Additionally, "lifestyle" is being recognized as another significant factor in motivating individuals to embark on the entrepreneurial journey (Ateljevic \& Doorne, 2000; Morrison et al., 1999; Shaw \& Williams, 2004). A study conducted by Dewhurst and Horobin (1998), found that there a large number of entrepreneurs in the tourism industry "who are not motivated by a desire to maximize economic gain, who operate business often with very low levels of employment and in which managerial decisions are based often based on highly personalized criteria" (p. 25). In a survey of rural business in Western Australia, Getz and Carlsen (2000) found that the majority of the respondents had strong lifestyle motivations of living and working in the countryside.

It is thus apparent that entrepreneurs are not a homogenous population and there may be different types of entrepreneurs, distinguished by their motivations, growth orientation, involvement in business operations, and so on. In order to better understand the phenomenon of entrepreneurship, Webster (1977) states that different "types of entrepreneurs should be singled out and treated individually to shed more light on what "makes them tick" (p.60). For example, in the case of lifestyle entrepreneurs, individual lifestyle motivations may serve to shape the entrepreneurs' decisions to run the business. The goals, objectives, challenges faced and strategies employed by lifestyle entrepreneurs may differ from other types of entrepreneurs. With all this in consideration, the next section aims to shed light on the emerging breed of 'lifestyle entrepreneurs'.

\subsection{Lifestyle entrepreneurship}

Lifestyle businesses can be found in a variety of different sectors. However, lifestyle as a key motivating factor seems to have been found predominantly in the tourism and hospitality sector (Andersson, Carlsen, \& Getz, 2002; Ateljevic \& Doorne, 2000; Getz \& Carlsen, 2000; Marchant \& Mottiar, 2011). Egoz, Bowring, and Perkins (2006) and Mailfert (2007) draw attention to the lifestyle focus of a number of farmers in the agricultural sector. Similarly, Marcketti, Niehm, and Fuloria (2006) observed lifestyle characteristics in a variety of sectors including food service, hospitality, apparel, retail and interior design. Eikhof and Haunschild (2006) point out the relevance of lifestyle motives for artists and individuals in the creative industries. 
The perceived nice life and prospect of living in an attractive location is another factor that appeals to many people (Marchant \& Mottiar, 2011; Peters, Frehse, $\&$ Buhalis, 2009). Some people successfully create a business around their desired lifestyle (Lashley \& Rowson, 2010) and manage to make profits out of their passion. In this way, lifestyle entrepreneurs can set up businesses which allows them to do the work they are passionate about while simultaneously making enough profit out of it. Marcketti et al. (2006) define lifestyle entrepreneurs as "individuals who owned and operated businesses closely aligned with their personal values, interests, and passions (p. 241)." Kaplan and Warren (2007) suggest that lifestyle entrepreneurs develop "an enterprise that fits their individual circumstances and style of life" (p. 10). Similarly, lifestyle entrepreneurs have been defined as individuals who design their entrepreneurial activity around preferred lifestyle and personal goals (Kaplan, 2003; Kaplan and Warren, 2007).

Interestingly, other characteristics that have also been associated with lifestyle entrepreneurship include: lack of skills, low education and training (Lashley \& Rowson, 2009); lack of management strategies (Morrison et al., 2001) and limited innovation (Ioannides \& Peterson, 2003).

According to Bridge et al. (2003), a lifestyle business is "run by an individual because it not only facilitates, but is also part of, the lifestyle that individual wants to have" (p.186). For some individuals starting a business aligned with their lifestyle motives equates to the realization of a dream (Lashley \& Rowson, 2010). Williams et al. (1989) suggest that lifestyle entrepreneurs tend to be experienced consumers who seek to find optimal customer-oriented solutions in the industry of their choice.

Marcketti, O'Neill and Cromie (2006), on the other hand, argue that lifestyle enterprises differ from other business start-ups primarily because "these businesses are frequently formed for the reasons associated with life quality: to provide outlets for sharing creative work or to provide flexibility in managing demands associated with work, family, and community roles" (p.242). In this way, lifestyle entrepreneurs pursue a desired way of life by shaping their business around their favourite activities. The notion of work-life balance and attaining a certain quality of life are central to lifestyle entrepreneurs. As Di Domenico (2005) notes, 'lifestyle' “implies a subjectively defined quality of life, which includes aspects of work, family and gender, 
as well as patterns of consumption, and how they relate to each other" (p. 120). Frederick and Chittock (2006) note that typically New Zealand entrepreneurs are opportunity-driven, focusing on attaining independence and work-life balance rather than maximizing wealth. Furthermore, it is suggested that New Zealand entrepreneurs tend to prioritize lifestyle objectives, which is evident by their focus on the 'three B's': boat, beamer (acquiring BMW cars) and bach (holiday house) (Frederick, 2006 cited in Luke, at al. 2007).

According to McGregor and Goldsmith (1998), an emphasis on quality of life differs between individuals, but at a general level can be described as "the perception of, and the level of satisfaction or confidence with, one's conditions, relationships, and surroundings" (p. 5). The lifestyle entrepreneur may choose to live in a particular location due to the appeal of quality of life attached to it. Marcketti et al. (2006) examined the relationship between lifestyle entrepreneurship and life quality and found two dominant themes emerging from their data: "enhancement of business owners' quality of life as a result of the entrepreneurial venture and a perception of the entrepreneurial venture providing enhanced quality of life to the employees, customers, and the community (p.241)." Therefore, it suggests that the quality of life concept goes beyond the entrepreneurs themselves, to include its benefits to other stakeholders as well.

In a study examining the lifestyle orientations of Scottish guesthouse owners, Di Domenico (2005) reported that 'the proprietors desired a certain 'way of life' as determined by their specific needs and wants, with the business being used as an enabling tool to acquire this "way of life"” (p.116). Similarly, Deakins and Freel (2006) point out that the primary motivation of lifestyle entrepreneurs is to live a desired quality of life by maintaining an income that allows them to survive. This is asserted by Peters et al. (2009), who argue that lifestyle entrepreneurs prioritize quality of life over profit maximization. Goulding et al. (2005), on the other hand, note that the lifestyle objectives in business tend to relate to quality of life concerns such as enhancement of personal relationships, personal growth and development, and achieving greater separation between work and leisure, just to name a few.

Living and working in a desired 'location' is identified as one of the key factors associated with quality of life (Peters et al., 2009). The attractiveness of the location 
is influenced by aspects such as climate, landscape, resources - to name a few (Stone \& Stubbs, 2007). As noted by Stone and Stubbs (2007), "a growing dimension of entrepreneurship is that associated with a relatively recent pattern of migration flows of people seeking lifestyle benefits in an attractive environment" (p. 433).

What is imperative to recognize is that economic performance measures do not essentially over-ride the non-economic measures in lifestyle business operations. A recurring theme in such businesses is the notion that non-economic attributes including motivations, aspirations and lifestyle values are balanced with and are at times prioritized over economic goals and objectives. For example, in a study of B\&B businesses in New Zealand, Hall and Rusher (2004) found that many entrepreneurs regarded lifestyle as a strategic business objective.

For lifestyle business operations, the commercial business and lifestyle goals may not always be totally aligned. In lifestyle businesses, even though emphasis is placed on attaining lifestyle and family-related goals, there is also some recognition of the importance of the business being profitable (Getz \& Carlsen, 2000). Economic objectives are of importance to lifestyle entrepreneurs as they provide the means to sustain the business and support the desired lifestyle of the entrepreneur. Like other types of businesses, lifestyle firms need to make money in order to remain viable. Carsrud and Brannback (2011) acknowledge that while lifestyle entrepreneurs may have economic goals and motives, these motives may not necessarily be to maximize economic gains. Rimmington et al. (1999) have classified lifestyle entrepreneurs as those "who are likely to be concerned with survival and maintaining sufficient income to ensure that the business provides them and their family with a satisfactory level of funds to enable enjoyment of their chosen lifestyle" (p. 13).

Traditionally, business performance is measured by economic criteria, based on either number of employees or financial performance such as profit, turnover or return on investment (Barkham et al., 1996; Kelmar, 1991). In addition to the economic criteria, researchers have identified "fulfilment of personal goals" as an important measure of entrepreneurial performance. For example, in a study conducted to explore the importance of various success factors to small business owners, Walker and Brown (2004) found that non-financial criteria including personal satisfaction, pride in job, achievement and flexible lifestyle were generally valued higher than 
wealth creation. Dawson et al. (2011) acknowledge that when measuring entrepreneurial success factors, social and cultural values must also be taken into consideration, rather than merely growth and development.

As can be seen in the preceding paragraphs, the existing research suggests that while making profits are important to lifestyle entrepreneurs, non-economic motives usually take precedence, such as the pursuit of passions, work-life balance, quality of life, and achieving personal goals and objectives. However, entrepreneurial goals and motivations are not static; they are fluid and highly changeable. A business that may have started for one reason may continue for another. For example, Marchant and Mottiar (2011) examined lifestyle entrepreneurs engaged in surf tourism businesses in Ireland and noted that for all businesses "the core business model at the start-up had focused on the lifestyle element but often circumstances had altered how they ran their business and many had grown either in response to demand or by accident which had resulted in temporary relegation of the lifestyle motives" (p. 179).

This indicates that even though entrepreneurs may establish a business primarily with lifestyle motives in mind, circumstances and the realities of running a business may lead them to prioritize other objectives, either temporarily or in the longterm. These circumstances could be related to a variety of factors including changing market trends, changing levels of demand, economic downturn, recession, financial loss in business, etc. Peters at al. (2009, p. 398) argue that "the rapid changes of the industry structures and the challenges emerging through globalization, competition, professionalism, industry concentration both vertical and horizontal, customer rights and strict regulation mean that many lifestyle entrepreneurs are quite unprepared for the threats emerging from the external environment".

Given that the theme of work-life balance consistently emerges in the lifestyle entrepreneurship literature, the next section addresses this concept in more detail.

\subsubsection{Work-life balance}

The prospect of achieving work-life balance and living a quality life appear to be key factors that motivate lifestyle entrepreneurs. The term "work-life balance" was 
first coined over 25 years ago in response to the trend of the 1970s and 1980s when people started prioritizing, to a greater extent, career goals and work over family, friends, community affairs, and leisure activities (Muna \& Mansour, 2009). Clark defines work-family balance as "satisfaction and good functioning at work and at home with a minimum of role conflict" (Clark, 2000, p. 349). In a similar vein, Marks and MacDermid (1996) view role balance as "the tendency to become fully engaged in the performance of every role in one's total role system, to approach every typical role and role partner with an attitude of attentiveness and care" (p. 421). These definitions share the common notion of equality, or near-equality, between the quality of functioning in, and the time allocated to both the work role and family role. According to Rouse (2013), one of the main goals of lifestyle businesses is to create and sustain desired work-life balance.

Balancing work and personal life with an approximately equal level of time, attention, involvement, or commitment is a key thrust from the work-life balance literature. The 'personal life' facet includes aspects such as family, leisure, travel, and hobbies (Li, Miao, Zhao, \& Lehto, 2013). In a study on work-life balance of bed-andbreakfast (B\&B) innkeepers, Li et al. (2013, p. 138) found that "entrepreneurial motivation moderates the relationship between work-life integration and work-life balance such that lifestyle-oriented B\&B innkeepers enjoy higher levels of work-life balance than business-oriented B\&B innkeepers".

Furthermore, many businesses in sectors such as tourism, hospitality, winemaking, agriculture, etc. are affected by the aspect of seasonality. These entrepreneurs may be faced with very demanding workload during certain times of the year, whereas at other times much less work is required on their part. This may present a challenge in regards to work-life balance, as researchers have argued: "The fluctuation in activity make it difficult in terms of hiring and retaining labour and staff - at certain times of the year, a large labour supply is required, whereas for other periods little labour is required" (Dawson et al., 2011, p. 555). Dawson et al. (2011, p. 552) further argue that "it cannot be assumed that all businesses want more tourism and greater sales by extending the tourism season; slow periods may be seen as an opportunity to rest, to spend time with family; not as a problem". 


\subsubsection{Lifestyle entrepreneurship and small businesses}

A large number of lifestyle businesses fall under the category of small businesses (Lashley \& Rowson, 2010). Typical criteria in defining a small business include small market share, non-separation of ownership and control and quantitative measures, such as number of employees (Massey, 2005). The criterion most commonly used is the number of people employed within the firm. Following the definition proposed by the Ministry of Economic Development (MED, now Ministry of Business, Innovation and Employment - MBIE, small and medium enterprises (SMEs) are those firms with less than 20 employees (MED, 2011). While these definitions may vary across different countries, the MBIE criteria for small businesses ensures that a similar percentage of New Zealand firms are classified in the SME category relative to other countries or regions (MED, 2011).

It is argued that small enterprises are not just scaled down versions of bigger firms but that their way of doing business is fundamentally different (Burns, 2001). Although the small business sector is not homogenous, small businesses have some common characteristics. As most small businesses tend to be owner-operated, the owners will identify closely with their businesses and the personality, behaviour, and characteristics of the owner-manager are likely to have an influence on the way the business is run.

Small firms also tend to be constrained in terms of limited financial resources. In many cases, the business is financed through the owners' family and/or personal savings (Glancey \& Pettigrew, 1997; Szivas, 2001). This may be due to the difficulty in accessing finance from formal sources such as banks and other financial institutions, which will inevitably have an influence on the growth potential of small businesses. Furthermore, due to their small size, they are also likely to have a small market share, making it difficult for these businesses to take advantage of economies of scale. However, in small firms this may be compensated by specializing and creating, or catering to, a niche market.

Researchers have highlighted the importance of non-economic, lifestyle related motivations to small business owners. Some examples include: the appeal of living in a specific location (Mottiar, 2007; Shaw \& Williams, 1987); to move away 
from hectic urban life (Alexander \& McKenna, 1999), and the freedom of being one's own boss (Lashley \& Rowson, 2009). Thus, there is likely to be an overlap between small business management issues and those faced by lifestyle entrepreneurs.

\subsubsection{Lifestyle entrepreneurship and family businesses}

A large proportion of lifestyle enterprises tend to be family owned and/or operated (Getz \& Carlsen, 2005; Lee-Ross, 2012). The involvement of family in the ownership and management of business is the basic characteristic of a family business. Sharma, Chrisman, and Chua (1997) define family business as "a business governed and/or managed on a sustainable, potentially cross-generational, basis to shape and perhaps pursue the formal or implicit vision of the business held by members of the same family or a small number of families" (p. 2). The "family" aspect in this literature is, though, usually an indicator of who owns and operates the business rather than why owner managers are in the business.

Another small but significant part of the family business literature addresses “copreneurship". Copreneurs are a type of family business (Bensemann \& Hall, 2010). The term "copreneurs" was coined by Barnett and Barnett (1988) and refers to married entrepreneurial couples that share ownership of, commitment to, and responsibility for a business (Barnett \& Barnett, 1988; 1989). These couples share entrepreneurial vision, goals, and risks in an intimate and dedicated partnership (Thompson, 1990). Thus, a business that effectively integrates work and personal domains appears to appeal to some couples. Fitzgerald and Muske (2002) argue that these couples (i.e. copreneurs) must share a work and personal relationship but not necessarily co-own the business. Interestingly, although the phenomenon of married couples working together appears common in practice, "copreneurs" have received little attention in academic research (Smith, 2000).

It is argued that "copreneurship" provides opportunity for couples to manage their work and family more flexibly and effectively than would be possible were they to work for someone else (Smith, 2000). Furthermore, Smith (2000) describes copreneurship as a "business lifestyle in which both partners are better able to manage their work and family responsibilities in accordance with their individual strengths and 
preferences" (p. 288). In a comparison of copreneurs and noncopreneurs, Fitzgerald and Muske (2002) found that copreneurs are more likely to view business as a way or life rather than a way to generate income. Similarly, the study undertaken by Bensemann and Hall (2010), in the rural accommodation sector of New Zealand, illustrates the non-economic, lifestyle motivations of many copreneurs running such businesses which include fulfilling the dream of owning a business, the ability to balance family and business responsibilities and the opportunity to meet new people (Bensemann \& Hall, 2010). Thus, these studies suggest that copreneurs and lifestyle entrepreneurs may share similar motivations and challenges.

\subsection{Business growth}

One of these challenges may be business growth. Growth of a business is commonly measured by an increase in number of employees, sales, and profit. A number of factors are likely to affect the growth of a business. In order to achieve growth in small businesses, it is important to identify the factors that facilitate and inhibit growth. It is argued that the growth in small businesses is influenced by the owner-managers' intention, ability and opportunity to grow. Table 3 presents a range of pro-growth factors and inhibiting factors that are likely to affect small businesses (Morrison, Breen, \& Ali 2003). Morrison et al. (2003, p. 418) note that "the progrowth factors represent owner-managers driven by the positives of a need, desire, and confidence to achieve, overcoming challenges presented in order to realize opportunities. The inhibiting factors represent a lack of desire to confront and/or to change factors at work at personal, business, and external environment levels". Since lifestyle business tend to small scale, it is possible that these factors may apply to them.

Table 3: Small Business Pro-growth and Inhibiting Growth Factors

\begin{tabular}{|l|l|l|}
\hline & Pro-Growth Factors & Inhibiting factors \\
\hline Intention & $\begin{array}{l}\text { Demographic variables } \\
\text { Personal characteristics } \\
\text { Values and beliefs }\end{array}$ & $\begin{array}{l}\text { Lack of ambition and vision } \\
\text { Anti-business "hobbyist" } \\
\text { approach }\end{array}$ \\
\hline
\end{tabular}




\begin{tabular}{|c|c|c|}
\hline & & $\begin{array}{l}\text { Quality of lifestyle protectionism } \\
\text { Mature position in life-cycle }\end{array}$ \\
\hline Ability & $\begin{array}{l}\text { Educational level } \\
\text { Knowledge of different fields } \\
\text { of business } \\
\text { Perception/actual of owner- } \\
\text { managers competence } \\
\text { Growth potential products, } \\
\text { assets and premises } \\
\text { Legal format of business } \\
\text { Proactive learning through } \\
\text { social, informal networks }\end{array}$ & $\begin{array}{l}\text { Constrained managerial } \\
\text { competencies } \\
\text { Narrow skills base } \\
\text { Physical expansion/production } \\
\text { limitations } \\
\text { Organisational structure results in } \\
\text { lack of time and resources }\end{array}$ \\
\hline Opportunity & $\begin{array}{l}\text { Market conditions } \\
\text { Access to finance } \\
\text { Public sector regulation } \\
\text { Labor market }\end{array}$ & $\begin{array}{l}\text { Weak power position within the } \\
\text { industry sector and markets } \\
\text { High dependency on externalities } \\
\text { Adverse financial and economic } \\
\text { conditions } \\
\text { Unhelpful local government } \\
\text { approach to business development } \\
\text { Constraining government } \\
\text { regulation and communication }\end{array}$ \\
\hline
\end{tabular}

Source: Morrison, Breen and Ali (2003, p. 419)

Morrison et al., (2003, p. 423) suggest that "each of the variable sets of the intention, ability, and opportunity are linked intrinsically, and business growth is unlikely to be achieved should one be missing or unduly weak". For example, it may be difficult for the firm to grow in a case where the market presented favourable opportunities but the entrepreneur lacked intention. Therefore, it is argued that the growth of an enterprise is at least partially determined by the intentions and motivations of the entrepreneur (Cliff, 1998). Poutziouris (2003) asserts that the "values, attitudes and motives of entrepreneurs shape the strategic goal setting and growth orientation of the business" (p. 188). Burns (2007) associates lifestyle firms with the owner-manager viewing the achievement of enjoyment from the activities 
undertaken as a primary motivation, while recognizing that the firm must also provide an adequate level of income. He argues that growth may not be a primary motivation for lifestyle firms, but that some of them can end up growing significantly in a way that influences their ability to maintain their lifestyle status. A number of studies have referred to lifestyle entrepreneurs as the opposite of growth-orientated entrepreneurs (Peters et al., 2009; Lee-Ross, 2012). Growth-orientated entrepreneurs can be described as entrepreneurs whose primary focus is on profit maximization (Timmons and Spinelli, 2004). They make regular attempts to engage in activities designed to increase sales and the market value of the business.

The research conducted by Ateljevic and Doorne (2000) in the tourism industry of New Zealand shows that once a business has been established, these lifestyle entrepreneurs may make a conscious decision to resist business growth opportunities. They go on to suggest that a number of these entrepreneurs opt to 'stay within the fence' in order to maintain their quality of life in their socio-cultural environment. Kuratko and Hodgetts (1998) assert that "neither large sales nor profits are deemed important beyond providing a sufficient and comfortable living for the entrepreneur" (p. 362). This indicates that one of the concerns affecting lifestyle entrepreneurs' attitudes towards business growth may be the expected changes in the characteristics of the business, consequent to growth (Wiklund, Davidsson \& Delmar, 2003). Thus, the tasks required of an entrepreneur are likely to change as the business grows. For example, if the size of business operations increases considerably, the entrepreneur may need to hire additional employees and/or delegate more responsibilities. These changes may sometimes clash with the initial goals of the entrepreneur, such as their desire for hands-on control, independence, personal contact with customers, etc. However, even though lifestyle firms may not establish the business with growth intentions, they may find there is a need to grow and develop the business in order to ensure survival and viability of business.

\subsubsection{Strategic Directions of Growth}

Entrepreneurs can employ a variety of different approaches in an attempt to grow their businesses. A potentially useful framework for conceptualizing such 
strategies is with Igor Ansoff's (1965) growth matrix. Ansoff's framework considers the strategic opportunities from offering existing and new products within existing and/or new markets. The matrix presents four alternative growth strategies; namely, market penetration, product development, market development, and diversification. Each of these four strategies has varying levels of risks attached to them. The greater the degree of newness in relation to product and/or market, the greater the assumed risk. Each of these will be described briefly.

\begin{tabular}{|c|c|c|}
\hline Market & Present & New \\
\hline Present & $\begin{array}{r}\text { Market } \\
\text { Penetration }\end{array}$ & $\begin{array}{c}\text { Product } \\
\text { Development }\end{array}$ \\
\hline New & $\begin{array}{r}\text { Market } \\
\text { Development }\end{array}$ & Diversification \\
\hline
\end{tabular}

Figure 1: Growth Vector Components

Source: Ansoff (1965, p. 99)

\section{Market Penetration:}

Market penetration involves increasing market share with existing market segments. This can be attained by selling more products/services to existing customers or by seeking new customers within existing markets. For example, in order to increase market penetration, a firm may make price adjustments, increase promotional efforts, etc. The familiarity with the product and the market helps reduce risks and uncertainties. Market penetration is considered to be the least risky of the four growth alternatives. 


\section{Product Development:}

Product development entails developing new products/services for existing markets. This involves developing new, innovative products/services to either replace or sell alongside the existing range. This may involve product improvements, product line extensions, new products to replace current products, new products to complement existing products, etc. Product development is perceived to have moderate levels of risk attached to it. It is perceived to be more risky than market penetration but less risky than diversification.

\section{Market Development:}

Market development involves finding new markets for existing products/services. This implies that the product remains the same, but it is marketed to a new audience. For instance, an existing product/service could be introduced to new demographic segments, new geographical segments, etc. Exporting the product to a new region is an example of market development. Similar to product development, market development has moderate levels of risk attached to it.

\section{Diversification:}

Diversification involves developing new products/services for new markets. It is considered as the highest risk strategy, as it requires the firm embark into an unknown market with an unfamiliar product/service, thus, putting itself in a position of great uncertainty. Diversification can be segmented into related diversification and unrelated diversification. Related diversification implies development beyond the existing product or market but within the broad confines of the industry. Unrelated diversification entails the development of completely new, unrelated products into new markets, beyond its present industry.

\subsection{Summary and Research Gap}

In summary, researchers are of the opinion that while making profits is important and essential to lifestyle entrepreneurs, non-economic motivations usually take precedence in their businesses. The theme of "balance" between economic and non-economic motivations has been much debated in the lifestyle business literature. 
From the review of existing literature, it is apparent that non-economic motivations such as passion, being one's own boss, attractiveness of living in a desired location, and work-life balance play a central role in the businesses of lifestyle-oriented entrepreneurs. However, in order to sustain and run a viable business, economic motivations are also important to lifestyle entrepreneurs.

Furthermore, while research has identified lifestyle entrepreneurship as a key facet of entrepreneurship generally, the research has not really addressed how these economic and non-economic motivations are being pursued simultaneously. More specifically, there is lack of research on the various obstacles that lifestyle entrepreneurs encounter in their attempt to pursue both economic and non-economic goals simultaneously. In addition, few studies have investigated how lifestyle entrepreneurs respond to these challenges; that is, the strategies employed to cope with business demands and personal considerations and concerns.

Moreover, although previous studies have addressed the phenomenon of lifestyle entrepreneurship, it has predominantly been in the context of the tourism and hospitality sector. Less research attention has been paid to other industries or sectors and particularly to wine industry where lifestyle entrepreneurship has been argued to occur. The present study seeks to further expand on the literature by examining these obstacles that lifestyle entrepreneurs might encounter as well as the means by and through which lifestyle entrepreneurs seek to overcome these obstacles in the context of the wine industry.

In conclusion, this chapter has presented a review of literature related to lifestyle entrepreneurship and identified areas that have not been explored in much depth. The next chapter outlines the research questions and the methodology employed for this study. 


\section{Chapter 3: Methodology}

\subsection{Introduction}

The previous chapter presented an overview of the literature across the various domains that relate to lifestyle entrepreneurship and highlighted the research gap, setting up the rationale of this study. In this chapter, the methodological underpinnings of the study are discussed in detail. The chapter begins by outlining the research questions that are central to this investigation. The chapter then goes on to describe the research design employed in the study including the type of approach used, sampling, procedures of gathering and analyzing data, and ethical considerations. Finally, some of the challenges encountered by the researcher during data collection and limitations of the research design are discussed.

\subsection{Research Questions}

The study addresses the following research questions:

1) What are the challenges encountered by lifestyle entrepreneurs in their pursuit of economic and non-economic motives simultaneously?

2) What strategies are employed by these entrepreneurs to cope with these challenges?

These research questions were formulated based on the research gaps highlighted in the previous chapter.

\subsection{Type of Approach}

Given the research questions above, this research is exploratory in nature. It aims to investigate various aspects of lifestyle entrepreneurship. Broadly, this study is concerned with understanding the perspectives and experiences of lifestyle entrepreneurs in the New Zealand wine industry. As highlighted in the previous chapter, lifestyle entrepreneurs run businesses so that they can do the work that they 
are passionate about while simultaneously making enough profit out of it. In lifestyle businesses, non-economic motivations are argued to take precedence over economic motivations. More specifically, the present investigation seeks to examine some of the difficulties associated with the operating a business in which lifestyle concerns outweigh economic motivations and, secondly, the ways in which lifestyle entrepreneurs attempt to overcome these challenges.

The research does not seek to test or develop specific hypotheses. It is aimed at theory development as opposed to theory confirming. Overall, an inductive, qualitative approach was used to examine the above stated research questions. Creswell (1998) defines qualitative research as "an inquiry process of understanding based on distinct methodological traditions of inquiry that explore a social or human problem. The researcher builds a complex, holistic picture, analyzes words, reports detailed views of informants, and conducts the study in a natural setting” (p. 15). Qualitative research is an interpretative approach, concerned with understanding the meanings that individuals attach to phenomena's such as decisions, actions, values, beliefs, etc. within their social worlds (Snape \& Spencer, 2003).

A qualitative approach was undertaken for a variety of reasons. The present study is concerned with exploring both particular challenges that lifestyle entrepreneurs encounter and the approaches used by lifestyle entrepreneurs to address these challenges. Perceptions and experiences of lifestyle entrepreneurs are likely to be complex in nature. This study aims to investigate the motivations, decisions, values and beliefs of lifestyle entrepreneurs. Broadly speaking, the study seeks to develop a detailed and extensive understanding of the various business practices adopted by lifestyle entrepreneurs. Exploring opinions and experiences of participants is better achieved using qualitative rather than quantitative approach. As Patton (2002) explains, "qualitative methods permit inquiry into selected issues in great depth with careful attention to detail, context, and nuance; that data collection need not be constrained by predetermined analytical categories which contributes to the potential breadth of qualitative inquiry" (p. 227).

Furthermore, this type of approach was considered appropriate as it seeks to build on limited knowledge about the various issues pertaining to lifestyle entrepreneurship. For example, little is known about the attitudes of lifestyle 
entrepreneurs relating to their orientation towards business growth, challenges that they encounter in business and how they manage to maintain their desired way of life while operating a viable business. It is arguable that light can be shed on these issues by gathering rich and detailed information on the perspectives and experiences of lifestyle entrepreneurs, which is possible through qualitative inquiry. This is because qualitative inquiry seeks to understand the complexities and intricacies of individual participants, while also seeking to understand commonalities in a group (Rountree \& Liang, 1996).

\subsection{Participant characteristics}

The present study focused on selecting a sample from within a single industry (the wine industry) as opposed to firms from multiple industries. This was done in order to maintain consistency in terms of participant characteristics. Firms from a single industry operate in the same business environment and offer similar products and services. Furthermore, since the participants competing in a single industry are influenced by the same market conditions, they are more likely to face similar business challenges, and conditions for financial viability. This enables the researcher to obtain rich comparable data.

The wine industry was deemed appropriate for this study, mainly because it has been associated to have lifestyle-oriented businesses operations (Dawson, Joanna, \& Cohen, 2011; Mitchell \& Hall, 2006; Scott Morton, \& Podolny, 2002). For example, many entrepreneurs in the wine industry indicate their passion for food and wine, the attractiveness of living on a vineyard, desire to be their own boss, personal satisfaction gained from producing high quality wines, expression of creativity through winemaking process - to name a few. The aforementioned factors pertaining to lifestyle orientation of winery owners are reflected in the quotes contained in Table 4 (see below), which are taken from the websites of a range of wineries. 
Table 4: Wineries indicating lifestyle orientation

\begin{tabular}{|c|c|}
\hline Wineries & The website states ..... \\
\hline $\begin{array}{l}\text { Beringer (Napa, USA) } \\
\text { http://www.beringer.com/about } \\
\text { (Retrieved: 12/09/2013) }\end{array}$ & $\begin{array}{l}\text { "Passion has the wonderful power to } \\
\text { turn mere objects into an obsession, to } \\
\text { transform everyday tasks into art. At } \\
\text { Beringer, we have been living our } \\
\text { passion for over } 138 \text { years". }\end{array}$ \\
\hline $\begin{array}{l}\text { Dutch Henry Winery (Napa, USA) } \\
\text { http://www.dutchhenry.com/estate/ } \\
\text { (Retrieved: 12/09/2013) }\end{array}$ & $\begin{array}{l}\text { "When Dutch Henry Winery opened its } \\
\text { doors in 1992, the Chafen's dream was } \\
\text { to quietly earn a reputation for quality, } \\
\text { passion in winemaking and an easy } \\
\text { going approach to sharing their story } \\
\text { with visitors to the winery. The dream } \\
\text { has blossomed, and each of the Chafens } \\
\text { has participated in the evolution of a } \\
\text { modest winemaking operation into a } \\
\text { producer of ultra premium Napa Valley } \\
\text { Wines". }\end{array}$ \\
\hline $\begin{array}{l}\text { Morton Estate (Hawkes Bay) } \\
\text { http://mortonestatewines.co.nz/about-us/ } \\
\text { (Retrieved: 12/09/2013) }\end{array}$ & $\begin{array}{l}\text { "We are fiercely committed to } \\
\text { winemaking as an art and not just a } \\
\text { business. This consistency has been at } \\
\text { the forefront of the Morton Estate brand } \\
\text { since its advent". }\end{array}$ \\
\hline $\begin{array}{l}\text { The Hill Family (Napa, USA) } \\
\text { http://www.hillfamilyestate.com/Our- } \\
\text { People/The-Hill-Family } \\
\text { (Retrieved: 12/09/2013) }\end{array}$ & $\begin{array}{l}\text { "Hill Family Estate was born out of the } \\
\text { desire for the family to work together. } \\
\text { Hill Family Estate is the culmination of } \\
\text { Doug's vision - a way to share his love } \\
\text { of the valley, of farming and of wine } \\
\text { with his children and wine lovers } \\
\text { everywhere." }\end{array}$ \\
\hline $\begin{array}{l}\text { Poliziano (Tuscany, Italy) } \\
\text { http://www.carlettipoliziano.com/eng/sto } \\
\text { ria.html } \\
\text { (Retrieved: } 12 / 09 / 2013 \text { ) }\end{array}$ & $\begin{array}{l}\text { "The inspiration for this investment } \\
\text { came more from the heart than from } \\
\text { economic motives. It was dictated by } \\
\text { my father's desire to maintain a living } \\
\text { contact with the place of his youth and } \\
\text { the culture of his origins." } \\
\text { "In over } 20 \text { years of vinicultural- } \\
\text { oenological management of my } \\
\text { company, I have never taken a decision } \\
\text { based solely on market indications. [...] }\end{array}$ \\
\hline
\end{tabular}




\begin{tabular}{|c|c|}
\hline & $\begin{array}{l}\text { Instead, my choices have been inspired } \\
\text { by a passion for agriculture and the real } \\
\text { excitement of imagining and conceiving } \\
\text { a vine, a grape, a wine, and of watching } \\
\text { them come to be after caring for them } \\
\text { closely every step of the way." }\end{array}$ \\
\hline $\begin{array}{l}\text { Chiarello Vineyards (Napa, USA) } \\
\text { http://www.chiarellovineyards.com/ } \\
\text { (Retrieved: 12/09/2013) }\end{array}$ & $\begin{array}{l}\text { "A labor of love, our wines are } \\
\text { sustainably farmed, carry the story of } \\
\text { my family in every glass and are simply } \\
\text { the most satisfying of all my personal } \\
\text { endeavours." }\end{array}$ \\
\hline $\begin{array}{l}\text { Locharburn (Otago, New Zealand) } \\
\text { http://www.locharburnwines.co.nz/The+ } \\
\text { Team.html } \\
\text { (Retrieved: 12/09/2013) }\end{array}$ & $\begin{array}{l}\text { "For us, Locharburn is the realisation of } \\
\text { our long-held dream. It gives both of us } \\
\text { the opportunity to indulge in our love } \\
\text { for wine and the lifestyle we chose for } \\
\text { ourselves" }\end{array}$ \\
\hline $\begin{array}{l}\text { Gibbston Valley (Otago, New Zealand) } \\
\text { http://www.gibbstonvalleynz.com/history } \\
\text { (Retrieved: 12/09/2013) }\end{array}$ & $\begin{array}{l}\text { "Alan had merely intended to indulge } \\
\text { his passion for winemaking as a hobby, } \\
\text { but now he was sure that there was a } \\
\text { serious wine to be made here". } \\
\text { "Alan's hobby had become a } \\
\text { commercial venture, and that venture } \\
\text { has now become a world-renowned } \\
\text { industry" }\end{array}$ \\
\hline $\begin{array}{l}\text { Gibbston Highgate Estate (Otago, New } \\
\text { Zealand) } \\
\text { http://www.gibbstonhighgate.co.nz/Vine } \\
\text { yard/history.htm } \\
\text { (Retrieved: 12/09/2013) }\end{array}$ & $\begin{array}{l}\text { "Growing up in Poland, Jacques spent } \\
\text { school holidays on his grandfather's } \\
\text { small farm and vineyard in Poland's } \\
\text { southwest and dreamt of someday } \\
\text { owning his own vineyard. Who would } \\
\text { have guessed we would end up in } \\
\text { Central Otago fulfilling this dream" }\end{array}$ \\
\hline $\begin{array}{l}\text { Herzog (Marlborough, New Zealand) } \\
\text { http://www.herzog.co.nz/about_herzog/ } \\
\text { (Retrieved: 12/09/2013) }\end{array}$ & $\begin{array}{l}\text { "Herzog is a family owned New } \\
\text { Zealand winery and restaurant, } \\
\text { supported by a unique team of } \\
\text { individuals who all share the same } \\
\text { values: a passion for wine and food, } \\
\text { commitment to excellence and quality, } \\
\text { and a love for the great New Zealand } \\
\text { environment" }\end{array}$ \\
\hline
\end{tabular}




\begin{tabular}{|l|l|}
\hline $\begin{array}{l}\text { Delegat (Marlborough, New Zealand) } \\
\text { (Retrieved: 12/09/2013) }\end{array}$ & $\begin{array}{l}\text { "Our story isn't about chance or luck, or } \\
\text { the many gold medals along the way. } \\
\text { Our story is about passion. A passion } \\
\text { for change. A passion to capture the } \\
\text { purist expression of the fruit. Not } \\
\text { accepting levels or limits of quality to } \\
\text { create one benchmark" } \\
\text { "You will find this passion in each } \\
\text { bottle of Delegat wine. Unreservedly" }\end{array}$ \\
\hline $\begin{array}{l}\text { Partington Wines (Nelson, New Zealand) } \\
\text { http://www.partingtonwines.co.nz/index. } \\
\text { html- (Quote 1) }\end{array}$ & $\begin{array}{l}\text { "Making organic wines is our joy. } \\
\text { Crafting the best organic wines in New } \\
\text { Zealand is our goal and our passion" } \\
\text { "Our philosophy is simple ... keep it } \\
\text { hilosophy.html- (Quote 2) } \\
\text { (Retrieved: 12/09/2013) }\end{array}$ \\
$\begin{array}{l}\text { simple, natural, and be passionate about } \\
\text { every aspect. If our passion for this ever } \\
\text { dries up we will simply stop doing it } \\
\text { and do something else" }\end{array}$ \\
\hline
\end{tabular}

Although all the wineries mentioned in the table above may not necessarily be lifestyle businesses, they highlight 'passion' and/or 'lifestyle' as being important factors. Similar statements are found on the websites of wineries in the regions of New Zealand selected for this study. However, in order to ensure confidentiality, those regions are not included in the table above.

\subsection{Sampling}

Lifestyle entrepreneurs in the New Zealand wine industry were purposefully selected. The type of purposive sampling used for this research is referred to as 'handpicked sampling' (O'Leary, 2004), where the participants are selected intentionally with a particular purpose in mind. Purposive sampling was used as it ensures that required participant criteria are met and maximizes the acquisition of rich, useful and valid data to address the research questions (Kuzel 1999; Esterberg, 2002; Easterby-Smith, Thorpe \& Jackson, 2008). 
For the purposes of selecting a sample for this study, the following criteria were used:

1) The entrepreneur established the business for reasons associated with passion for business, non-economic motivations, and making profits

2) The business must be family owned and operated

3) The entrepreneur must have hands-on involvement in business operations.

These criteria overlap somewhat but should ensure that the wineries selected match key characteristics of lifestyle entrepreneurship. In order to maintain consistency and minimize researcher bias in the identification of suitable participants, the defining criteria used was very specific, catering to only lifestyle entrepreneurs in the family businesses. Although lifestyle entrepreneurship is not exclusive to family businesses, many family firms tend to have a lifestyle orientation, as illustrated in the previous chapter. It is also acknowledged that not all lifestyle entrepreneurs may have hands-on involvement in their businesses. However, since lifestyle businesses are closely linked with passion for work and enjoyment derived from work, it is likely that the entrepreneur may have a more hands-on approach; being more personally involved, and more active, in the day-to-day running of the business.

The research questions sought information that could be best answered by the lifestyle entrepreneurs themselves. Being the owner and operator of the business, the entrepreneurs were in a position to provide unique insights into the way they run their business and the various challenges they may encounter. Lifestyle entrepreneurs were seen as particularly suitable for illuminating and extending the researchers understanding of various issues pertaining to their businesses, since these entrepreneurs are responsible for the decisions, strategy, and directions of their winery. Although most of the lifestyle businesses included in the present study were jointly owned and operated by two or more members of the family, only one owner was interviewed for each business. Most businesses had only one contact email provided; therefore the email was sent to the contact person. In few others, the contact email of both copreneurs was provided, in which case an email was sent to both of them. However, in both cases, only one entrepreneur from each winery agreed to participate. This was potentially due to time constraints on part of the interviewees.

One of the key criticisms of the handpicked sampling technique is that it cannot statistically be assessed for representativeness, leading to the issue of generalizability 
across the relevant sample population (O'Leary, 2004). However, since the purpose of this study was not primarily to generalize the findings across the entire sample population, but rather to study the selected sample in-depth and improve understanding of complex entrepreneurial issues, this was seen as the appropriate method. The researcher aimed at looking for patterns and themes across the selected sample. Where patterns occurred broadly across the sample these were viewed as more generalizable. A total of 25 wineries were contacted to participate in the research, of which 14 agreed to participate. Given the time constraints of this thesis, a sample size of 14 participants was deemed reasonable. A sample size between 12-15 subjects is usually considered adequate for conducting rigorous qualitative research (Eisenhardt, 1989).

\subsection{The Research Context}

In order to enhance the diversity of data collected, the sample consisted of participants from three wine regions of New Zealand which have a reputation for wine making, including Nelson, Martinborough and Waiheke Island. These regions were selected mainly for the reason of geographical proximity. Due to lack of driving skills, the researcher had to rely on public transport as a means of reaching interview destinations and the vineyards in these locations tended to be centralised and hence accessible. The regions selected were largely pragmatic choices, given the constraints of the research timeline and allowed data to be collected expeditiously. Each of these regions is characterized by a large number of small-scale wineries. Furthermore many of them are family owned and operated. These factors were taken into consideration as it was noted in the literature review that lifestyle enterprises are likely to be smallscale and have a tendency to be family owned and operated. The interviews were carried out in the months of October 2012, November 2012 and February 2013. Due to summer being a very busy time for wineries, no interviews were scheduled during that period. 


\subsection{Method of Data Collection}

Data for this study were collected through in-depth, semi-structured interviews. Interviews were well-suited to this kind of study, given that the present research questions needed to be examined in depth, and the researcher wanted to capture the ideas, thoughts, experiences and perceptions of the participants (McGehee, 2012). The semi-structured nature of the interviews allows participants the freedom to express their opinions with only minimal direction; reducing the likelihood that responses would be unduly influenced by the interviewer's personal biases and preconceptions. Furthermore, semi-structured interviews provide the researcher with the opportunity to probe the participants further, in order to increase the richness and depth of responses and get a better idea of the issues being addressed and to give cues to the participants about the level of response desired (Patton, 2002; Saunders, Lewis, \& Thornhill, 2009). Examples of some probes that were used include questions such as 'how did that come about?', 'what was the nature of your involvement?', 'what did you do?' etc. Prompts were also used to elicit deeper levels of responses where necessary (Patton, 2002).

All interviews were carried out face-to-face and were approximately 60 minutes in duration. Cavana, Delahaye, and Sekaran (2001) suggest that face-to-face interviewees have the capacity to "encourage the interviewee to share intrinsic opinions and to dredge previously unthought-of memories from the unconscious mind. This rich and rare material invariably includes tacit knowledge from the interviewee" (p.138). In addition, face-to-face interviews enable the researcher to account for body language and non-verbal forms of communication often missed in other types of data collection. Furthermore, it gives the researcher an opportunity to adapt the interview questions as necessary and clarify any doubts that respondents may have. However, a major drawback of face-to-face interaction is that the participant may feel uncertain about the anonymity of their responses (Cavana et al., 2001). To address this, the research information sheet and research consent form had an explanation stating that the analysis from the interviews would be reported in an aggregated, non-attributable form and that neither their name nor their organization's name would be mentioned in the study. Assurances of confidentiality were also verbally reiterated to participants at the start of each interview. 
A thorough internet search was initially conducted to identify suitable wineries in the Nelson, Martinborough and Waiheke Island regions. The websites of individual wineries were used as the first point of reference in contacting wineries. Approximately, 25 wineries from the three regions were approached to participate in the present research project. The invitations to participate, accompanied by an information sheet broadly outlining the study, were first emailed to a few wineries in the Nelson region. There was, however, no response from any of the wineries for several days. These wineries were then contacted by a follow-up telephone call and some business owners explained, as a reason for non-response, that they did not consider their wineries to be 'lifestyle' but, rather, 'serious businesses'. However, the characteristics of these businesses, as described on their individual websites, were consistent with the definition of lifestyle entrepreneurs used for this study. When an explanation was given to them about how the term was being used, a few of them subsequently agreed to participate.

Once this problem was identified, the researcher decided to change the title on the information sheet from 'Lifestyle Entrepreneurship in New Zealand Wineries: Motivations and Business Strategies' to 'Generating Profits out of Passion: A study of New Zealand Wineries'. The remaining content of the document remained the same. When wineries in the other two regions (i.e., Martinborough and Waiheke Island) were invited to participate in the proposed research project, they received the modified information sheet. Following this change to the information sheet, it was noticed that fewer follow-up calls were required; most of the wineries that were contacted expressed interest in participating. Some wineries still declined to participate, however, with the most common reason being lack of time. A few businesses indicated that they were simply "not interested" in participating. In total, 14 wineries from the three regions - Nelson, Martinborough, Waiheke Island - agreed to participate in the research. One entrepreneur from each winery was interviewed.

The interviews were carried out with individual entrepreneurs at their place of work. Before commencing the interviews, the participants were explained the purpose of the study and were asked to fill out a research consent form. All interviews were digitally recorded with the permission of the participants. In order to guide the direction of interviews, the researcher used an interview outline consisting of several open-ended questions. The open-ended question format was adopted as it encourages 
interviewees to share their perspectives and experiences in their own words, in a style that they find comfortable, and in depth (Patton, 2002). In contrast to closed questions in which a range of preselected responses are offered and the participants are required to pick the response option that best reflects their situation, open-ended questions provide the flexibility to allow respondents to say exactly what they want to say about a given topic.

Given that the present study is exploratory in nature, the research questions were broadly framed in an attempt to produce rich and detailed data. The interview questions were designed in accordance with the research questions and the relevant themes drawn out from the literature (Eriksson \& Kovalainen, 2008). The questions were based several main topic areas including the motivations for entering the business, goals and objectives, strategies employed, growth and development, and challenges encountered. An interview outline can be found in appendix C. In order to minimize the subjectivity bias during the interviewees, neutrality was maintained pertaining to the content of the participant's responses. The researcher did not convey favour or disfavour in regard to what the participants said. Once all of the researcher's questions had been administered, participants were given the opportunity to raise and discuss any further issues related to the topic.

\subsection{Data Analysis}

Following data collection, all interviews were carefully transcribed and initial impressions noted. In order to ensure confidentiality, the researcher personally transcribed all the interviews. This was a highly time-consuming process. However, listening to the interview recordings numerous times lead the researcher to develop a high degree of familiarity with the data (King \& Horrocks, 2010). The data were analyzed inductively. Inductive analysis "involves discovering patterns, themes, and categories in one's data. Findings emerge out of the data, through the analyst's interactions with the data, in contrast to deductive analysis where the data are analyzed according to an existing framework" (Patton, 2002, p. 453). Once all interviews had been transcribed, each interview transcript was read a number of times for greater familiarity and various regularities were observed (Miles \& Huberman, 1994). They were then coded and categorized into emerging themes and sub-themes. Codes were 
not predetermined prior to data collection; rather they were identified from the interview transcripts.

\subsection{Ethical Consideration}

Human Ethics Approval for this study was obtained from Victoria University of Wellington, prior to commencing the data collection process. Each interviewee was provided with an information sheet outlining the general purpose of the research, an explanation of why they were selected, details about the time and location of interview and the nature of topics that would be covered in the interviews. The interviewees were also asked to sign a research consent form assuring participants the confidentiality of their responses. They were informed that the data would be reported in a non-attributable form and neither the name of the interviewee nor their winery would appear in the results reported. They were also made aware that they could withdraw the information they provided at any time prior to the commencement of data analysis. Copies of the research information sheet and the research consent form can be found in appendices A and B respectively.

In order to ensure that the voice of the participants is not lost in interpretation, direct quotations from the interview transcripts will be used in the findings and discussion chapters. Patton (2002) suggests that "direct quotations are a basic source of raw data in qualitative inquiry, revealing respondents' depth of emotion, the ways they have organized their world, their thoughts about what is happening, their experiences, and their basic perceptions" (p. 21). Due to confidentiality reasons, the interview participants will be referred to with disguised names.

\subsection{Challenges and Limitations}

The main issue associated with adopting a qualitative approach is that it may be subject to biases on the part of the researcher. Qualitative research involves relying heavily on the researchers own interpretation. In other words the present research requires two levels of interpretation: firstly the participants' interpretations of their own experiences, attitudes, and beliefs, and, secondly, the researcher's interpretation 
of the respondents' interpretations. Thus, the interpretative process could be susceptible to bias, both in terms of what the participants report and in terms of what the researcher emphasises in the analytical and reporting stages of the research process.

In addition, the lifestyle businesses identified by the researcher may not be representative of other lifestyle business in the wine industry and those who agreed to participate may differ from those who, once approached, declined to participate. However, having conducted the interviews in three wine regions of New Zealand (Nelson, Martinborough, Waiheke Island), some degree of confidence can be expressed in terms of the theoretical generalizability of the findings to the New Zealand wine industry as a whole.

Furthermore, including the criteria of being family owned and operated could also be seen as a limitation as it excludes lifestyle operations in other types of businesses (e.g. sole-proprietorship, partnerships and joint ventures). It is possible that the perspectives of lifestyle entrepreneurs in family businesses may differ from the perspectives of lifestyle entrepreneurs operating in other types of businesses. Similarly, the present research focuses on lifestyle entrepreneurship specifically in the wine industry of New Zealand, excluding businesses with lifestyle-orientation in other industries. Although the findings of this study may not be directly generalizable to lifestyle entrepreneurs in other industries, it is likely that lifestyle entrepreneurs in other industries may also face similar challenges. For example, since lifestyle entrepreneurs in the tourism industry are also in the pursuit of their passion, they are also likely to face the challenge of achieving desired lifestyle objectives while simultaneously running an economically viable business.

\subsection{Summary}

This chapter discussed the research methods used in this study and provided the rationale for the chosen methods. A qualitative approach involving in-depth semistructured interviews was used as a means to gather primary data. The interviews were conducted face-to-face with 14 lifestyle entrepreneurs in three wine regions in New Zealand. All interviews were digitally recorded and later transcribed. Data were then 
inductively analyzed. The next chapter will present the results obtained by employing these methods. 


\section{Chapter 4: Findings}

\subsection{Introduction}

The previous chapter discussed the process by which my research was conducted. The findings that emerged from that research process are presented in this chapter. The study set out to examine two key aspects of lifestyle entrepreneurship; namely, the challenges encountered by lifestyle entrepreneurs in their pursuit of economic and non-economic motivations simultaneously and the strategies employed by these entrepreneurs to cope with these challenges. In analyzing the data collected, several interesting themes emerged. These themes are reported in this chapter; further interpretation and discussion of these themes will be conducted in the next chapter. In order to retain the voice of the respondents, direct quotations from the interview transcripts are used in this chapter.

This chapter comprises three main sections. The first section presents the profile of the respondents and reports their motivations, goals and objectives in relation to their business. The second section focuses on the themes generated in relation to the first research question (i.e. the challenges encountered by lifestyle entrepreneurs) and the third section presents the themes identified in relation to the second research question (i.e. the strategies employed by lifestyle entrepreneurs to cope with those challenges). The chapter concludes with a summary that brings together key findings from this chapter.

\subsection{Profile of Participants}

A total of 14 wineries from three regions in New Zealand participated in the study. Of the 14 family businesses comprising the sample for this study; 9 businesses were run by copreneurs and the other 5 had broader family involvement. The sample included 5 wineries from Nelson, 7 wineries from Martinborough and 2 wineries from Waiheke Island. Due to confidentiality reasons, the original names of each winery will not be used. Instead, the wineries have been assigned disguised names based on their regions (e.g., the 2 wineries from Waiheke will be referred to as 'Waiheke A' 
and 'Waiheke B'). The sample consisted of 10 male respondents and 4 female respondents. There was great variation in the age of respondents (ranging from 35 years to 70 years). The period of existence of these wineries also varied, ranging from 5 years to 32 years. However, there did not seem to be significant differences in the issues faced by the wineries based on their period of existence. In order to ensure that the individual wineries are not identifiable, the gender of the respondent and the exact age of their business are not mentioned in the table. Responses did not appear to be different for female vs. male respondents. A more detailed profile of the participants is presented in Table 5 .

Table 5: Summary of Participant's Profile

\begin{tabular}{|c|c|c|c|c|c|}
\hline $\begin{array}{c}\text { Disguised } \\
\text { Name of } \\
\text { Winery/ } \\
\text { Vineyard }\end{array}$ & $\begin{array}{l}\text { Key motivations for } \\
\text { running the } \\
\text { business }\end{array}$ & $\begin{array}{c}\text { Age of } \\
\text { business }\end{array}$ & Business operations & $\begin{array}{l}\text { Education } \\
\text { and/or } \\
\text { previous } \\
\text { experience } \\
\text { in industry }\end{array}$ & $\begin{array}{c}\text { Number } \\
\text { of full- } \\
\text { time } \\
\text { employees }\end{array}$ \\
\hline Nelson A & $\begin{array}{l}\text { - Passion for wine } \\
\text { - Personal satisfaction } \\
\text { - } \text { Sexse of accomplishment } \\
\text { - Recognitition } \\
\text { - } \text { Making financial profits }\end{array}$ & $21+$ & $\begin{array}{l}\text { - Vineyard } \\
\text { - Winemaking } \\
\text { - Cellar Door } \\
\text { - } \text { Domestic wine sales } \\
\text { - International wine exports }\end{array}$ & No & $1-5$ \\
\hline Nelson B & 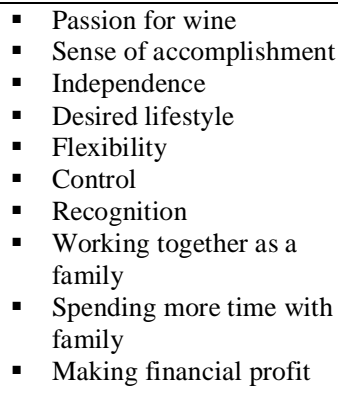 & $21+$ & $\begin{array}{l}\text { - Vineyard } \\
\text { - Winemaking } \\
\text { - Cellar Door } \\
\text { - Restaurant/Cafe } \\
\text { - Domestic wine sales } \\
\text { - International wine exports }\end{array}$ & Yes & $6-10$ \\
\hline Nelson C & 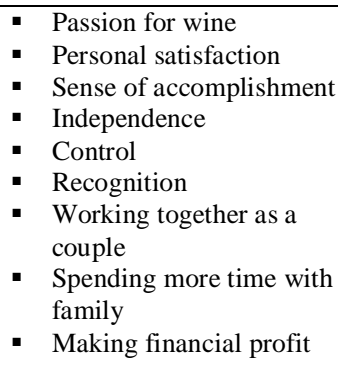 & $11-20$ & $\begin{array}{l}\text { - Vineyard } \\
\text { - } \text { Winemaking } \\
\text { - } \text { Cellar Door } \\
\text { - } \text { Restaurant/Cafe } \\
\text { Domestic wine sales }\end{array}$ & No & 0 \\
\hline Nelson D & $\begin{array}{l}\text { Passion for wine } \\
\text { - } \\
\text { Independencence } \\
\text { - }\end{array}$ & $1-10$ & $\begin{array}{l}\text { Vineyard } \\
\text { Grape sales to other } \\
\text { winemakers }\end{array}$ & Yes & 0 \\
\hline
\end{tabular}




\begin{tabular}{|c|c|c|c|c|c|}
\hline Nelson $\mathbf{E}$ & $\begin{array}{ll}\text { - } & \text { Passion for wine } \\
\text { - } & \text { Control } \\
\text { - } & \text { Recognition } \\
\text { - } & \text { Corking together as a } \\
\text { - } & \text { Making financial profit }\end{array}$ & $21+$ & $\begin{array}{l}\text { - Vineyard } \\
\text { : } \text { Winemaking } \\
\text { - } \text { Cellar Door } \\
\text { - } \text { International wine exports }\end{array}$ & No & $1-5$ \\
\hline Waiheke A & $\begin{array}{l}\text { - } \text { Passion for wine } \\
\text { - } \text { Sense of accomplishment } \\
\text { - }\end{array}$ & $11-20$ & $\begin{array}{l}\text { - Vineyard } \\
\text { - Winemaking } \\
\text { - } \text { Cellar Door } \\
\text { - Restaurant/Cafe } \\
\text { - } \text { International wine exports }\end{array}$ & No & $6-10$ \\
\hline Waiheke B & $\begin{array}{ll} & \text { Passion for wine } \\
\text { - } & \text { Personal satisfaction } \\
\text { - } & \text { Independence } \\
\text { - } & \text { Desired lifestyle } \\
\text { - } & \text { Flexibility } \\
\text { - } & \text { Recoognition } \\
\text { - } & \text { Working together as a } \\
& \text { couple } \\
\text { - } & \text { Making financial profit }\end{array}$ & $1-10$ & $\begin{array}{l}\text { - Vineyard } \\
\text { - Winemaking } \\
\text { - } \text { Cellar Door } \\
\text { - } \text { Destaurant/Cafe } \\
\text { - } \text { International wine sales }\end{array}$ & No & $6-10$ \\
\hline $\begin{array}{l}\text { Martinborough } \\
\text { A }\end{array}$ & $\begin{array}{ll} & \text { Passion for wine } \\
\text { - } & \text { Personal satisfaction } \\
\text { - } & \text { Flexibendence } \\
\text { - } & \text { Control } \\
\text { - } & \text { Recognition } \\
\end{array}$ & $11-20$ & $\begin{array}{l}\text { - Vineyard } \\
\text { - Winemaking } \\
\text { - } \text { Cellar Door } \\
\text { - } \text { International wine exports } \\
\text { - } \text { Grape sales to other } \\
\text { winemakers }\end{array}$ & No & $1-5$ \\
\hline $\begin{array}{l}\text { Martinborough } \\
\text { B }\end{array}$ & 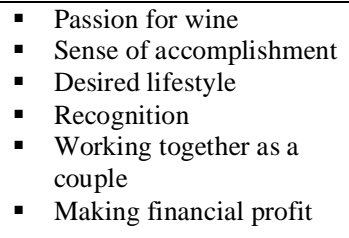 & $11-20$ & $\begin{array}{l}\text { - Vineyard } \\
\text { - Winemaking } \\
\text { - } \text { Cellar Door } \\
\text { - Domestic wine sales }\end{array}$ & No & $1-5$ \\
\hline $\begin{array}{l}\text { Martinborough } \\
\text { C }\end{array}$ & $\begin{array}{ll} & \text { Passion for wine } \\
\text { - } & \text { Personal satisfaction } \\
\text { - } & \text { Flexibility } \\
\text { - } & \text { Control } \\
\text { - } & \text { Spending more time with } \\
& \text { Making financial profit } \\
\end{array}$ & $21+$ & $\begin{array}{l}\text { - Vineyard } \\
\text { - Winemaking } \\
\text { - } \text { Cellar Door } \\
\text { Domestic wine sales }\end{array}$ & No & $1-5$ \\
\hline $\begin{array}{l}\text { Martinborough } \\
\text { D }\end{array}$ & 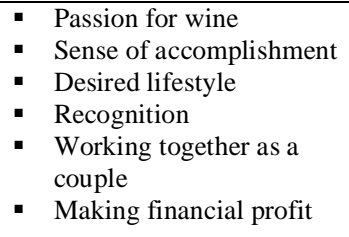 & $1-10$ & $\begin{array}{l}\text { - Vineyard } \\
\text { - Winemaking } \\
\text { - Domestic wine sales } \\
\text { - } \text { International wine exports } \\
\text { winemakers sales to other }\end{array}$ & No & $1-5$ \\
\hline $\begin{array}{l}\text { Martinborough } \\
\text { E }\end{array}$ & $\begin{array}{l}\text { - } \text { Passion for wine } \\
\text { - } \text { Personal satisfaction } \\
\text { - } \text { Independence } \\
\text { - } \\
\text { Desired lifestyle } \\
\text { Making financial profit }\end{array}$ & $1-10$ & $\begin{array}{l}\text { Vineyard } \\
\text { - Winemaking } \\
\text { - Domestic wine sales } \\
\text { - International wine exports }\end{array}$ & Yes & $1-5$ \\
\hline
\end{tabular}




\begin{tabular}{|c|c|c|c|c|c|}
\hline $\begin{array}{l}\text { Martinborough } \\
\text { F }\end{array}$ & $\begin{array}{l}\text { - Passion for wine } \\
\text { - Personal satisfaction } \\
\text { - } \text { Desired lifestyle } \\
\text { Working together as a } \\
\text { couple } \\
\text { - } \text { Making financial profit }\end{array}$ & $11-20$ & $\begin{array}{l}\text { Vineyard } \\
\text { - Winemaking } \\
\text { - Domestic wine sales } \\
\text { - } \text { International wine exports } \\
\text { - Accommodation (Holiday } \\
\text { house) }\end{array}$ & No & 0 \\
\hline $\begin{array}{l}\text { Martinborough } \\
\text { G }\end{array}$ & $\begin{array}{l}\text { - } \text { Passion for wine } \\
\text { - } \text { Independence } \\
\text { - } \text { Conibility } \\
\text { - } \text { Recognition } \\
\text { Working together as a } \\
\text { couple } \\
\text { - Spending more time with } \\
\text { family } \\
\text { Making financial profit }\end{array}$ & $21+$ & $\begin{array}{l}\text { - Vineyard } \\
\text { - } \text { Winemaking } \\
\text { - Cellar Door } \\
\text { - } \text { Domestic wine sales } \\
\text { International wine exports }\end{array}$ & No & $6-10$ \\
\hline
\end{tabular}

The range of business operations that the respondents were engaged in included grape-growing, winemaking, domestic wine sales, international wine exports, providing accommodation on the vineyard (holiday house), cellar-door sales, and restaurant/cafe facilities. Most respondents reported that they started the business with the core operations, namely grape-growing (all respondents) and wine-making (13 respondents). All respondents were directly involved in the grape growing process and wine production process with the exception of one respondent (Nelson D) who was not involved in the wine production process. In terms of wine production, 10 respondents reported that they employ a winemaker whereas the remaining 3 produce their own wine. All the respondents that employ a winemaker indicated that they are still actively involved in the wine production process and they closely monitor and work with the winemaker. In addition to these core operations, 10 respondents reported that they were engaged in cellar door sales, 10 were involved in international wine exports, 13 were involved in domestic wine sales (local/nationwide restaurants, liquor/wine stores, mail delivery), 4 respondents operated a restaurant/café on-site, 3 respondents engaged in grape sales to other winemakers and 1 respondent offered accommodation service (holiday house) on the vineyard.

Only 3 out of the 14 respondents indicated that they had either a qualification in viticulture or had some sort of work experience in the wine industry, prior to starting their businesses. All businesses had achieved at least some level of growth since inception, but all of them still remained small in size (employing less than 20 employees). At the time when the participants were interviewed, four respondents indicated that they employed 6-10 full-time employees, seven indicated that they 
employed 1-5 employees, and three indicated that they didn't employ any full-time employees. The scope of business operations was naturally related to the number of full-time employees.

There do not appear to be systematic differences across regions, suggesting that the sampling is unlikely to have affected the generalizability of the results. The sample of wineries selected for this study were broad in range, with significant diversity in the sample; and variances in age, size, and operations. For example, there was a mix of both old and more newly-established wineries, some wineries were relatively bigger/smaller in size than the others, other wineries had diversified into restaurant/café operations and there was one that provided accommodation facilities which allowed guests to stay on the vineyard. Furthermore, some wineries were engaged in sales solely with domestic markets, whereas some others were active in both the domestic and international markets. Clear patterns between these activities and demographic characteristics were not evident though.

\subsection{Motivations, Goals and Objectives}

In order to confirm the validity of the sample participants in terms of their lifestyle characteristics, each respondent was initially asked questions about their motivations, goals and objectives for establishing and running the business. As can be seen below, a large number of the sample wineries tended to emphasize non-economic motivations rather than economic motivations. However, this is not unexpected given that the sample was identified specifically to focus on lifestyle entrepreneurship, that is, entrepreneurs who are noted to have both types of motivations.

\subsubsection{Non-economic}

For all respondents, their primary motive to establish/run the business was at least partially non-economic in nature. The following non-economic themes were identified. 


\section{Flexibility and Work-life balance:}

Most respondents indicated that they had started their businesses for reasons relating to the desire for flexibility in managing work demands and to better achieve work-life balance. More specifically, 10 respondents reported that the ability to spend more time with family and work with family were key motivating factors in establishing their businesses.

For example, Nelson C stated, "we were looking to do something as a family, as an investment and also something different, you know, that we could do together". The respondent goes on to say "it was a kind of bonding time and a time for us to invest our money into something that we enjoy". Nelson D commented, "it's good and handy to have the business right at home. As soon as I walk out of the door the vineyard is right there and you don't have to get in your car and drive 20 minutes to get there [...] you can call in for lunch and your [spouse] is in the lawn with the kid running around and there is some baking. It is quite nice to be at home in that environment". Martinborough E suggested, "I actually fully think that that's [work-life balance] quite an important part, balancing life with business. I love it and I embrace it and I think it's a fabulous way to live your life"

\section{Passion:}

Passion also comes across as an important motive in establishing and running the business. All respondents indicated a strong passion for wine, and some, more specifically, for wine-making. For example, Waiheke A highlighted, "I started this business because I had and still have a strong interest in food and wine [...] the motives weren't financial, the motives were to do something that I was interested in". Similarly, Waiheke B stated that "we've always had a love of fine food and wine so we wanted to pursue that a little bit further [...] we thought it would be a fun thing to do, it's a romantic idea, to have our own vineyard, to make our own wine". Another respondent, Martinborough $\mathrm{C}$ highlighted "it was absolute passion, in fact it was beyond passion; it was bloody obsession".

Nelson D claimed, "I love working outdoors. I love the grapes. I love nature. I just love being outside with the birds and insects and, you know, things like that [...] 
so yeah I do like it; I'm passionate about it which some people think I'm nuts. I can't be passionate about work but I see it as a bit of a hobby really. I turn up to work and I go home-I'm happy, it's a great lifestyle”. Nelson A pointed out, "it is quite easy in this industry to be passionate about it. It lures in a lot of people in the first instance. There is a romanticism associated with making wine which I don't think applies to any other industry really. There is something quite unique and special about working with grape vines and producing grapes and converting that into a nice wine and you get a good sense of satisfaction from it and I think that's what lures people into it". Waiheke A commented, "if you don't have passion, you won't succeed".

\section{Desired lifestyle:}

For a number of respondents, the opportunity to pursue a desired lifestyle was a key factor underlying the decision to establish a wine business. As pointed out by Waiheke B, "so clearly this size of business is a lifestyle choice, not purely a moneymaking choice. It is the sort of business where it is possible to make some money but it is not, I wouldn't recommend it to someone who is trying to get in to make their first million necessarily. You really need to make some money before and come to this later and accept that it is a lifestyle choice; it can be profitable". Martinborough G commented "it's a great business to be in because of its complexities and its relatively healthy lifestyle". Martinborough D stated, "the motivation to start here was that, we had been working in the city for all our life, so I was sort of looking for a retirement place and not a retirement place to do nothing but to do something, something of our choice." Similarly, Martinborough F highlighted, "we like the lifestyle, so it was the idea that it's partly lifestyle, it's partly not having to retire because you have to work all the time. So it was potentially a good alternative to the other work that I was doing [...]. We weren't looking to make lots of money; we were looking to support lifestyle if anything”. Martinborough D commented, “lifestyle, it's really nice. I love living in the country. I come from [...] you know lived in the country, never been used to the big city".

Living in a good location was another factor that some of the respondents pointed to as being important to them. Martinborough E commented, "I guess there is a side of the coin I haven't really discussed yet which is the dream to raise a family in 
a beautiful space. For me, it's a satisfying place to work and live my life as well”. Likewise, Nelson A stated "we are on a nice little property and our kids have grown up with access to a nice environment, handy to good schools, certain levels offreedom that perhaps children in the urban environment might not get. It's a healthy kind of an upbringing. I think it's great from the family lifestyle point of view”. In a similar vein, Martinborough B highlighted the desirability of: "living on a property like this, continuing to live on a property like this where you've got a beautiful outlook, nice climate, opportunity to garden".

Thus, although profits and the long-term sustainability of the business were important to respondents, they tended to emphasize lifestyle benefits, particularly the benefits derived from living in a rural area, and living an active and healthier lifestyle.

\section{Other non-economic motivations, goals and objectives:}

Some other non-economic motivations, goals and objectives indicated by the respondents included such factors as the desire for control, independence, personal satisfaction, sense of accomplishment, and recognition of achievement in the wine business. These factors, are apparent in the following comments:

Nelson A: "there is a certain satisfaction in being the boss or you know the person who drives the business". Martinborough E: "I approach this business as an artist really and it is an opportunity for creativity and pleasure [...] there is a certain intrinsic reward that comes from looking back at your work, from being independent operator, from arguably following your dreams, having the ability to follow your dreams and not having to convince someone that they should go down this path and then ultimately they'll take the glory for you know your hard graft". Waiheke A: "to make one of the great red wines of New Zealand and to have one of the great winery restaurants in New Zealand".

Nelson C: "we have had a lot of pleasure from the place, we enjoy it [...]. I really like it here, and that's very special to us because we have made this place from nothing and you know we get a lot of pride out of seeing what we have created and that's special to us". Martinborough F: "making wines is very interesting and producing good wine is very satisfying". Waiheke B: "I think more for us it's a 
lifestyle choice, it's more the sense of accomplishment having created something from scratch [...] so that gives us a lot of personal satisfaction, regardless of the other actual financial side of the business".

Martinborough D: "we want to make the best wine that we possibly can make and better than everyone else maybe [...] the satisfaction that we succeeded in making good wine”. Martinborough A: "if we produced bad wine, we would tip it out because that is not what we are trying to do. We are trying to tell a story about ourselves and we are striving to produce the best wine that we possibly can". Nelson E: "we always wanted to make the best wine possible, be recognized for that".

As can be seen above, many respondents stated that their passion for quality wine, the lifestyle that such businesses afford, and the satisfaction derived from the wine-making process, were important factors underlying their decision to enter the wine business and were also constant sources of motivation and inspiration. Overall, the researcher was struck by the high level of enthusiasm conveyed by respondents when they discussed their businesses, which they often described as being modestly profitable, personally fulfilling, and highly enjoyable. Respondents often referred to owning a vineyard and making wine as a somewhat romantic notion that many, including themselves, have been seduced by.

\subsubsection{Economic}

Economic motivations, goals and objectives were also important to the respondents. All respondents indicated that one of their key objectives was to earn adequate income in order to ensure viability of the business and support their chosen lifestyle. For example, in the view of Nelson A, "there's no point being successful if you are a dead duck in the water and you are not making any money. There is no success in making the best wine in New Zealand or the world or anywhere if at the end of the day you are financially bankrupt because you can't continue to do it - so you've been successful in terms of making the wine but you know your business is not a success. You actually have to be driven by the dollar unless you are one of the very fortunate few where it is a play thing for the rich". The respondent further emphasized this point: “you've got to be conscious of the financial background to it, you can't just 
live in a fantasy, oh I'm living a perfect lifestyle and all boards will come, you also have to be conscious of the background that if you have to live this lifestyle it has to make a return".

When asked about business goals and objectives, another interviewee (Martinborough A) responded "only to make a viable business at what was a great interest of ours, which was wine [...] you are trying to run a financially sound business, you are trying to make sure that the expenses don't exceed the income [...] you've got to keep your feet on the ground about where the revenue is going to come from, how you are going to sell the wine. It is alright making a lot of wine but then you've got to sell it". Martinborough E noted, "it's about the independence and the satisfaction but also arguably the profitability if you do it correctly to a degree. I'm not driven by economy that much but ultimately it is inevitable that we need to make enough money to survive". Martinborough C: "as long as I can afford to keep opening my door, afford to make wine and afford to eat, I think I'm doing alright at the end of the day". Martinborough F: when it can support me, when it can support my family, then it [business] will be successful"

Thus, it is clear that along with non-economic motivations, economic motivations play a key role in lifestyle entrepreneurship. Earning adequate income in order to ensure the survival and smooth functioning of the business was important to all respondents. The respondents, however, did not put much emphasis on maximizing financial profits. The emphasis was more on earning enough money to enable respondents to support and maintain their desired lifestyles.

\subsection{Challenges encountered by lifestyle entrepreneurs}

The main challenge encountered by these lifestyle entrepreneurs was that of balancing economic and non-economic motives simultaneously in their businesses. In an attempt to strike this balance, lifestyle entrepreneurs are likely to encounter a number of sub-challenges. The following section presents a description of the various barriers the respondents face in the course of operating a lifestyle orientated business. 


\subsubsection{Issues pertaining to growth of business}

All respondents reported that they had achieved some form of growth (e.g., market penetration, diversification, etc.) over time, but all of them still remained relatively small-scale. This seemed to be conscious decision, rather than the result of a lack of market success.

For instance, Martinborough A commented, "we don't want to grow only, because if we get bigger we will lose the hands-on impact that we want to have on the wines, in the vineyard and in the winery". Waiheke B suggested, "I guess there is a point at which it would get beyond our not capacity but beyond our desire to manage [...] it's one of the most difficult things for a small business I think to maintain that level of personalized service and as they grow two, three, four, five times the original size".

Similarly, Nelson C pointed out "if you make things a lot bigger then you really can't be a part of it as easily, I don't think. And there is nothing like having personal touch but to do that you need to stay small and stay focused on, you know not being too big”. Martinborough F expressed, "I'd still want to have a fairly hands-on role in terms of $[\ldots]$ because it's the physical aspect that attracts me; I enjoy it". Martinborough E commented, "I try to produce enough wine that I get some efficiencies of scale and that I can actually generate enough income for my family, small family sort of thing, support myself comfortably [...] I don't want to be greedy, I don't want to go bigger than that".

In sum, the lifestyle entrepreneurs interviewed described an ongoing tension inherent in the running of small-scale lifestyle businesses - namely, the desire to adopt a hands-on approach and enjoy a high-level of personal involvement in the management of the business, while also generating enough profits to be sustainable and support a comfortable living for the entrepreneur and his/her family. Thus, while business growth and profit generation were important to all respondents, they seek to achieve a balance between often competing economic and non-economic goals, one in which the pursuit of economic gain does not interfere with the entrepreneur's desire for autonomy, control, and a high-level of personal involvement in business management. However, respondents indicated that a number of factors related to 
business growth or, more specifically, increased pressure to prioritize the pursuit of profits, served to hamper the attainment of lifestyle objectives. These factors, which include business competition, financial constraints, environmental conditions, influences of external business environment, and succession of business, are outlined in the paragraphs that follow.

\section{Competition:}

Competition was highlighted as a key issue by many respondents in relation to the growth of business. In some cases, the entrepreneurs had established their wineries when there was very little competition in the market. These entrepreneurs suggested that it was relatively easier during those times to pursue lifestyle objectives as they did not necessarily need to focus on business growth to such a great extent. However, as more and more wineries entered the market place, and competition increased, many respondents were required to change their business priorities and, particularly, their attitudes towards growth. A number of respondents pointed out that they had to grow their business in order to remain viable. The quotes below are a good indication of how competition influenced the businesses of the respondents.

Nelson E pointed out, "what we did [...] years ago we wouldn't repeat if we were you know if it was to happen today. The whole wine industry has moved on so much, it is highly competitive now. Yeah you know we didn't have the vast resources that most people setting up in the wine industry do today you know the whole situation of the time has changed [...] the whole industry back then was much friendlier, smaller, everyone sort of co-operated and helped everyone else but yeah today it's quite different”. Martinborough D commented, "in hindsight, well I probably wouldn't have done it [establish this business] again. But things changed so quickly since we started; too much vine was planted worldwide, the economic downturn didn't help and so you know most wineries are suffering a bit. Some a bit more than the others but most of us are in the same boat. We have to work quite hard to sell the wine and even if we have good quality it doesn't matter, the price point is more important these days, so yeah we have to do more marketing and offer more specials you know". Similarly, Martinborough A explained, "twenty years ago, small wineries often produced bad wine and the public was quite forgiving. It was small, it was hand-made, they didn't 
expect a lot of it and didn't probably get either. Today, it's not like that. Even though the wineries are small, they are producing wine as good as or even better than anything that is produced [elsewhere] in New Zealand. And that is a big difference to what it used to be like. If a small winery produced bad wine today, it wouldn't sell anything because people want value for money".

\section{Financial Constraints:}

A number of respondents reported that they had a desire to grow their business but were constrained by financial resources. As expressed by Nelson A, "capital is one of the main difficulties in the wine industry, it is very capital intensive to grow the business. Whatever you do, lot of money has to go in it. You have to plough that in and then you have to wait because there are delays, that is, filtering back through profitability, so you lay out a lot of money into a new vineyard [...]. That in itself requires more investment in the winery in terms of tanks and presses or pumps or storage facility and eventually it has to be put into bottles and so on". In a similar vein, Nelson E stated, "we can only grow as much as we can sell, so we are always constrained to a certain extent by finances [...]. While it would be nice to go out and buy a new tractor tomorrow, we can't do that you know we have to probably make-do with what we've got until we've got our next crop and so we've expanded slowly over time”.

Martinborough B stated, "we bought some land and planted a vineyard and then went to work full-time to help sustain it [...] we need external income, yes; we have large mortgages, so we need external income to help cover the cost of mortgages [...] the main conflict would be when we are both working full-time; trying to juggle this business alongside demanding corporate jobs and finding the time". Martinborough B highlighted, "you know there are things that we would like to do that we don't have the money to do, things that we would like to try but the financial implications are such that we can 't afford it'. The same respondent was of the opinion that "there is not a lot of help often to start in New Zealand and there is not a lot of help from the government in New Zealand to export or do anything like that, you stand very much on your own and you have to be sustainable. It's one of the reasons a lot of 
vineyards are currently in financial difficulties and selling, there are no subsidies in agriculture in general and none in viticulture”.

Martinborough D echoed a similar idea in that "sometimes things you want to do, its finance [...] we haven't got massive finance, everything I had was put into business and we are struggling to even breakeven, with the downturn economically, with the glut of wine [...] banks are afraid to lend too much to vineyards because there are too many you know, they have borrowed already too much". The respondent further explained 'it's sort of like we are established and we have enough income to keep the operations going and live off it but there is no excess money left [...] we thought by now we would have more regular income and say there would be a surplus to do certain things, maybe expand the winery a little bit or get new equipment but [...] at the moment it is a neutral sort of business you know, no surpluses. We still exist and we can still keep going but it could be a lot better [...] we are not going to rock the boat and get more debt and expand and have more worries". Furthermore, Martinborough F pointed out, "the money that we have invested into the business is the money that we had, so there's no debt. So the only way we can recoup the money that we've invested is if we sold because we don't make enough money out of what we produce to pay up capital".

From the quotes above, it is apparent that for these respondents, business growth was limited by the availability of finance. The respondents pointed out difficulties in raising finance, particularly for growth and development of their businesses. Many respondents were dependent on personal and/or family investment for financing the business. The main reason for not seeking outside help was indicated as not wanting to be in debt. However, some respondents did seek loans from external sources such as banks and other financial institutions in order to establish their business.

Furthermore, 4 respondents reported that their businesses were not robust enough to support them fully. Therefore, they had to be engaged in additional employment in order to sustain their businesses. The remaining 10 respondents indicated that their businesses were self-sustaining, 


\section{$\underline{\text { Environmental conditions: }}$}

Respondents emphasized the challenges wrought by environmental conditions (unexpected changes in climate, bad weather conditions); that can have a significant deleterious impact on vineyard operations. One such pressing concerns was that bad weather could ruin the entire crop, resulting in huge financial loss.

As expressed by Martinborough A, "one of the biggest challenge for us was that working in the city you can control your environment and you know that when you buy a vineyard you can't control the environment. But until it actually happens you don't appreciate how much of an impact it has on how you actually run your business. You can't work in the dark and in the city you can; you can't work when it is raining, in the city you can; you have to do things in a particular order because of the way the plants grow, [....] it's the weather that dominates everything and it takes a number of seasons before you have to understand that you can't change it. What your job to do is to live with it and work around it". Martinborough B commented, "oh Mother Nature does challenge you [...] it depends on nature, there's not much you can do about it [...]. At the moment it is critical because the weather is variable and we have the risk of frost, so that puts a bit of pressure into the business".

Martinborough A highlighted, "along the way we had a couple of really disastrous harvest due to weather and that was more than what we had predicted. One year we had only $20 \%$ of what we estimated. So the weather had quite a big impact on us”. Similarly, Martinborough D pointed out, “we got some very dry years, some very wet years. It was a big challenge in those years to grow good quality grapes which would make good quality wine".

Thus, it seems clear that grape growing, like most horticultural endeavours, is at the mercy of weather conditions and climate. Respondents recounted instances where unfavourable environmental conditions had severely hampered the business operations of the vineyard and had resulted in huge financial loss. Thus, it seems that, due to the unpredictability of weather conditions, many respondents were reluctant to grow their businesses should they require excesses capital to cover the losses of a bad season. 


\section{$\underline{\text { External business environment: }}$}

A number of respondents also expressed concern for factors such as fluctuation in demand and changing market trends. For instance, Nelson D highlighted, "there is a whole industry risk where, you know, wine production is exceeding demand for wine [...] the varietal changes, fashion changes of wine, people stop drinking [...] and start drinking a variety of [...] that I have not planted or something, that's a risk that I would have to change plantings". Nelson A asserted, "it's always things like changing consumer demand for different variety wines, for example. You grow a crop and society doesn't automatically say, oh yes, we are going to drink your wine. Traditionally people used to drink a lot of Chardonnay and then they decided that was out and Pinot Gris was in, so Pinot Gris had to be added to the list".

Waiheke A pointed out, "the recession that started with the GFC [Global Financial Crisis] four years ago has meant that the business has plateaued but that's simply a function of the customer sentiment out there. People aren't running around spending money like they used to". Similarly, Martinborough A commented, "it is more difficult now than it was originally because with the recession, pricing is always an issue [...] we haven't been able to raise our prices very much at all whereas our costs have gone up which are beyond our control. And that means our margins have got smaller"

\section{Succession of business:}

Succession planning was another factor that was considered by a few wineries in relation to growth. Generally, the respondents whose children/other family members were not going to take over the business in the future, were hesitant to grow the business.

Nelson C expressed that "we are quite happy to be content in the small nucleus that we have created because our children are probably not going to continue with the business. So it's something that my husband and I [run], it's our baby, you know, and we are quite happy to just keep it the way it is really". Martinborough F conveyed that "if our family decided that they wanted to come and get into the business and so on then we would definitely be looking at growth". Martinborough B: "wondering what 
we are going to do with the business long-term in terms of succession planning because it doesn't look like our family want to do anything with it. So I guess ultimately it will be sold".

The age of the business and the age of the respondents also appeared to have an influence on their growth orientation. Most respondents had established the business when they were between the ages of 25-45. There were few others who had established it between the ages of 45-65. A few of the older respondents indicated that they were not interested in growing the business for the reason that as they grow older, it becomes harder for them to retain hands-on control.

Martinborough C: “I don't think we are going to change it very much, we are just going to keep it the same as it is but try and run it as economically and as efficiently as we can, definitely”. Waiheke A: “well, we've enjoyed good business growth in our time [...] I don't want to grow the business further. I'm happy with the way it is". Nelson D: "at this stage in the industry, I'm planning further growth, kind of coinciding with paying off debt". Martinborough B: "sometimes having the energy, as we grow older. Like many people around the Martinborough area, a lot of us started when we were considerably younger and we are ageing and if you are small like us, you don't always have a lot of staff available due to economic conditions".

\subsubsection{Issues pertaining to achieving desired work-life balance}

The respondents highlighted various issues pertaining to achieving the desired work-life balance. These are discussed in the following paragraphs:

\section{Lack of free time:}

A number of wineries encountered the issue of not having enough 'free time'. Some wineries mentioned that they had quit their previous jobs in the pursuit of this business with the notion that they would have more free time, but in the course of running the business they came to realize that they in fact have less free time for 
recreation or simply getting away from business activities. In the course of addressing the issue of work-life balance, the respondents commented:

Waiheke B: “it's certainly kept us busy. It's been fun, it's been entertaining, we've created a new product but that's the only case where it's failed to meet an expectation of hope that we will have more free time and now we have less free time". The respondent goes on to say that "it's just the balance between work and play is a bit different than what we had originally anticipated [...] I mean we are doing all we wanted to do; we are making fine wines, we are winning lots of awards for them and it's going well. It's just that it's taking a lot more of our time than I thought it would". Another respondent, Nelson E: "the fact that you have to do everything, you are here constantly, we live on-site, you never can get away pretty much”. Similarly, Martinborough B: "you don't have any downtime and when you are working in a business like this which is 24 hours a day, 7 days a week, 52 weeks of a year. So that's a big trade-off, you know you can't suddenly decide that you are going for a week's holiday because you have to look at what's happening to the business".

Nelson B: "we are working sixteen hour days for six weeks and there is no getting away from that, I mean when you harvest grapes and make wine that's what happens [...] we are the decision makers, we are the ones in charge, who's going to do that. You know it's our name on the bottle, so that probably could be a problem in terms of work-life balance, the pressure from the spouses and stuff". Nelson E: "I wouldn't tell anyone to get into it for lifestyle anymore. It's a lot of hard work and it's hard to get away from you know. You are in charge and responsible for everything from growing the grapes through making of the wine to the marketing of the wine, so you have to be Jack of all trades really". Martinborough G: "you have to enjoy working all the time because there are a thousand things to do in front of you".

Nelson D: "all I do is work. I had a holiday last week actually, it's the first one I had for a long time. I had to leave Nelson to have a holiday because I have tried to have holidays at home and I have ended up working all the time [...] I should reprioritize and spend more time with family. And even friends, I've noticed that I have less friends since I'm at work all the time". Nelson A: "the amount of time and commitment often meant that you worked long and hard and when something needed doing you just went out and did it. It doesn 't matter whether it's the weekend, it doesn't 
matter if you wanted to have a week off or something. We worked for a number of years with very little time off and a lot of time going into business. And that in itself should we say creates a platform for a bit of stress and family conflict".

\section{Boundary between work and personal life:}

The boundary between work and personal life appears to be blurred in the case of some respondents. These respondents acknowledge for them work and family time is not clearly demarcated. Martinborough A: “it's hard to say I must have a strong work life, I must have a strong private life, they are totally intertwined with each other". Nelson B: "we are having family dinners here or Christmas dinner or you know, you are always at the worst danger of work chit-chat. But you know I don't consider it as work chit-chat. It's just our lives, but outsiders could perceive that differently and might not be so happy with the work talk”. Similarly, Martinborough C: "It is your life. You end up working for more hours than you ever wanted to, you wake up in the middle of the night because you've thought of a solution or because you think something is going to happen".

Living on-site poses further conflict in terms of defining clear boundaries between work-time and personal-time. Martinborough D: "the one thing that we probably should have done earlier on; buy a house off the site instead of living on the vineyard". Martinborough F: "I mean you do work most of the time especially when you live on the site". Nelson E: "and you never really get away or when you do get away you are worrying about what's happening back here and so that's difficult in terms of lifestyle”.

Many wineries raised the matter of having to work very long hours. Some of them maintain that it is not a problem as they enjoy the work they are doing. Nelson A reflects back on some of the earlier years and says "it wasn't unusual to work 1214 hour days, 7 days a week, you know it is sort of the commitment we put in. But again, for the most part, it was enjoyable, it didn't feel like a drag or difficulty". Similarly, Martinborough G highlights "I just feel like I am double booked virtually every day, during the day and at night, you know. It's very busy, you are basically open to the public the whole time. I mean some wineries are not open for that reason, 
but you know we like the contact with our customers". However, in working such lengthy hours, it raises a question as to whether work is in fact dominating lifestyle for these entrepreneurs.

\section{Seasonality in business and nature of business operations:}

The respondents also highlighted that during busy periods, they were required to work, irrespective of the fact that it was a weekend or a public holiday. Due to the nature of the business operations that the respondents were involved in, particularly operations such as the cellar door sales and the restaurant/café, they were required to work most weekends. As the following quotes illustrate:

Martinborough A: "the time you would want to go on a holiday which would be summer time, over Christmas, we are very busy because the grapes are just starting to flower and fruit and the quietest time for us is after harvest which is really the end of April, early May, probably when you wouldn't normally want to go on a holiday. But that's the time we have to go away". Nelson B: "you might want a holiday you know but the grapes don't go on holiday. It's our livelihood, you can't just walk away from it for two weeks over Christmas and New Year's Eve. Somebody has to be there to look after the crop [...] you just can't go home and turn off your phone and that's the end of it until next week, you've got to be there to deal with the issues".

\section{Organisational management issues:}

Generally, due to lack of economic resources, it was difficult for respondents to employ staff to manage the different business operations. Therefore, in order to ensure smooth functioning of the business, the respondents were required to possess a range of skills and comprehensive knowledge about the various aspects pertaining to the business. Eleven respondents indicated that they had no experience in the wine industry or qualification in viticulture, prior to starting their own business. They pointed out that they acquired the required skills on the job, mostly through a protracted, and ongoing, period of trial and error learning. The following quotes provide some insights: 
Martinborough B: "you don't always have a lot of staff available due to economic conditions, so I suppose that's a challenge; just keeping on top of all the tasks that need to be done, there is always a long to-do list”. Martinborough B: “[...] so that's been a huge learning curve for me, I've had to get my head around that because that's not my knowledge area". Nelson E: “on the vineyard, pretty much learnt on the job for the first 3-4 years when we only had [...] acres. As I said back then the industry was pretty friendly [...] but times have changed now, and now people would employ two full-time people who are experienced in vineyards, so you tend to employ more specialists”. Martinborough D: “we are trying to delegate more work to permanent staff. But there are times you know that certain things we have to do ourselves. You know you can't, well unless you had a manager that you could give everything away but we can't afford to pay for manager to control the business and live ourselves, so we have to be our own manager".

The general well-being and health of the respondents is also an important factor, as the work might suffer immensely (especially during busy periods) if the respondents were to unexpectedly take days off work. The following quotes illustrate this point:

Martinborough C: "there is no back-up staff, it's just me, so if you are sick you shut shop and then you have got to go to be open [cellar door] so that's certainly one of the challenges, being a one man band". Nelson E: "you'll probably put in more hours than if you worked for someone else in reality and we certainly don't pay ourselves [...] if something happened to either of us, obviously it's going to be a lot of pressure for the other person. I mean if we were sufficiently a large company and if someone, if your winemaker leaves it is not such a big deal, you get another one. Here we can't replace either [...] or myself with someone on our salary because no one would work for what we work for".

In relation to business planning, most entrepreneurs indicated that they did not undertake formal business planning. These respondents indicated that they made business decisions as and when deemed necessary. Only 4 respondents suggested that they developed a formal business plan. Those that did have a business plan indicated that they would on the whole follow through the plan and revise it every year. 
Generally, the respondents reported that there is a great need for flexibility and adaptability in their business operations.

Martinborough A: "we try and operate a no surprises business, that is what we really try to do. We try and think in advance of what we are going to do, program that in and get on at it [...] and so we set a plan for the year and it has to be flexible because of the weather". Nelson C: “well because we are owner-operator, my [...] and myself, we are a very small team, so it (planning) happens all the time, you know, when you are sitting at the dinner table we are talking about things, just everyday interactions, we are always discussing what we could do". Nelson E: "while it's nice to have these written plans I've come to a conclusion that it is not really worth the paper they are written on; we just take things as they come really".

\subsection{Strategies employed to cope with the challenges}

In order to cope with the above mention challenges, the respondents employed the following strategies:

\subsubsection{Growth Strategies}

The prevalence of non-economic influences alongside economic factors were apparent in the decisions made by the respondents pertaining to growth of the business. For a few respondents, the changes in external business environment and the increase in competition spurred the adoption of new business operations (e.g. establishing a restaurant/café).

Martinborough B acknowledged "if I look back over the past five years, our business has grown considerably". Nelson C: "Initially we didn't have our little cellar door and we just made a small one and then gradually we thought oh well why don't we make it more interesting and add a bit of a café to it in the summer". In addition to adding the café, the respondent further decided to increase the varieties of wine on offer, so that customers get a range of wine to choose from for when they dine in café. The respondent comments, "we thought to get the variety when people come here particularly in the café, they can have six different choices that will match any kind of food, so we don't have to bring in anyone else's wine and we can promote our own 
wine”. Martinborough B: “[...] that diversification would mean that hopefully we'll be able to sell all of our wine".

Martinborough A: "not all wineries that are the same size have the same strategy and you'll see what their strategy is just by the way they appear in the market place. I mean some people will sell all of the wine directly to customers through the tasting room or a facility like that, others would want to sell only to distributors and some want to do a whole mix of things [...] it's very rare that you get a blinding flash of inspiration; improvements are incremental and you set about doing things differently again in incremental ways". Nelson E: "we are trying at the moment to find as many new markets as possible [...] we want to grow the business more so that we can employ more people and take a slightly lesser role on the operations side. Otherwise all we are doing is working 24 hours a day [...] we would never take a backseat obviously but not have to do quite as much as we do".

Instead of increasing the volume of production of existing operations/ products/services, the respondents chose to diversify into related operations. This enabled them to keep the existing business small-scale and also engage in the activities of the business that they (most) enjoy. For example, some respondents established restaurants/cafes to encourage customers to consume and purchase wine. By making these changes to the businesses, respondents sought to increase profits in a way which enables them to retain hands-on involvement in the various business operations and enhance personal contact with the customers.

According to Waiheke B, "passion is one of the most important aspects of getting the business off the ground and to be successful not just because we do all the work but because people coming to experience your business can feel the passion coming through". Martinborough E commented, "I'm in pursuit of quality and I believe that it's not about producing more and making more money, it's about exploring new potential, new sites, new plantings [...] as a producer and a creator, there's always an excitement in understanding the unknown or you know beginning to play with the unknown a little bit you know in terms of getting a feel for it and experimenting and that sort of stuff. So there is always some attraction to try something new and to keep life exciting". 
Nelson A: "you have to change over time because sometimes when you set up you can't foresee what are going to be the benefits or the challenges and so on, so you just basically have to be versatile and adaptable and see where the benefits are going to be and what direction to take where you want to go". Martinborough F: "we were originally only growing grapes for contracts. We didn't have a contract with anybody when we started and so when the grapes came on the vines was when there was a silence in the industry; so we decided that instead of selling the grapes we would make wine instead". Martinborough B: "when (the copreneur) initially planted this vineyard [...] was following one aspect of the dream but hadn't really thought about the long-term, how do we potentially sell 20,000 bottles a year [...] You know you can't keep producing it without selling it, so that aspect of the business has become much more formalized and changed a lot, so we've had to go out and look for distributors, we've had to go out and look for restaurant markets to supplement what we can sell through the cellar door".

As the respondents diversify their business operations, they may also be required to delegate more responsibilities and potentially need to hire specialized staff for the various areas of operations. This would subsequently involve the respondents spending more time and money in monitoring/overseeing the work of the employees. Some respondents indicated that they really enjoyed the hands-on involvement in the tasks, so they would prefer to do the tasks themselves rather than take a back seat. One respondent in particular was very reluctant to delegate tasks. This respondent (Martinborough $\mathrm{C}$ ) stated that: "well half the time when I do delegate, they do the bloody job wrong anyway and I'm doing it again". The next section provides further insight into the issue of delegating responsibility to staff.

\subsubsection{Delegating responsibility as business grows}

With the growth of their businesses, a number of respondents noted that there was need to delegate more responsibility to staff. The respondents indicated a desire to maintain overall control of business operations in their own hands, but were willing to delegate some responsibility to staff. A number of respondents pointed out that delegating tasks afforded a number of benefits, such as allowing them more free time, 
and the opportunity to better achieve work-life balance. Also, a few respondents pointed out that for certain tasks, where they lacked knowledge and experience, for example, they found the need to employ specialist staff. The respondents indicated that they closely monitored delegated tasks and expressed a desire to retain some level of involvement in these operations. Since most of the respondents preferred to have hands-on involvement, they often found it difficult to detach themselves completely from the various operations. Respondents also commented that it was easier to delegate tasks that they were less interested in, as opposed to those that they were passionate about. Typical comments were as follows:

Waiheke B: "we've been training various members of staff to give us the potential to for getting away from time to time and where they could just potentially manage the operations particularly on quieter days [...] we have to experiment a little and see how comfortable we feel about that. It is very difficult to let go of your baby". Nelson A: “we've grown the business [...] and that has enabled me to perhaps have more time off and greater freedom than I had [...] years ago [...] I think that's part of the growth of the business, you have to lay the foundations, put the hard work, hard effort in, then as it starts to build you can afford to take on staff to help you and so on [...] so [...] years ago I would have been out on that tractor doing the mowing, I would have been doing the spraying, I would have been doing everything. I would then have to come in late in the day, sit down and do a lot of paperwork, look at orders, arrange things. You know it was fairly full on. It was nothing to work an 80 hour week”. Nelson B: "we have a lot of staff obviously to help us but in terms of the management, the leadership, the decision-making that's us. We wouldn't hand that over to somebody else".

Martinborough D: "you learn from your mistakes, yeah. Some mistakes that we made in the beginning; we thought we could do everything ourselves but we learned very quickly that we have to employ specialists for marketing, sales, you know we couldn't go on and see enough people to sell the wine, we were busy enough up here". Martinborough A: "we decided that winemaking was a really fine mix of science and craft and we thought it was bit of an insult in a way to imagine that I could step up and make this great wine from scratch. Yeah, we thought we needed a professional". Nelson C: "I think we have very high standards and we like to do the best we can if anything and part of that is being very hands-on [...] for example, we 
have a bottling day in two weeks' time and I personally have been down and gone over the dry goods together and delivered them to the plant and talked to the person who is doing it and making sure it's going to be the way we want it you know. And I've been involved in ordering the labels and you know talking to the winemaker and making sure that the wine is god and trying the wines, testing the wines. And before that we've been part of picking of the grapes, the growing of the grapes, deciding when to put the sprays on, or when to thin the grapes, or when to leaf pluck".

Another respondent reported the desire to delegate certain tasks but was limited by finance and commented, "there would be some things I would very much like to delegate more. Areas where whilst I have the skill but I don't have the pleasure of doing them. For example, I would like to get a sales rep on the road doing that. I can do it but I don't enjoy doing it. I have got my head around the social marketing side reluctantly, I'd be very happy to give that away to somebody as well. So yes there are some things that we could delegate more" (Martinborough B).

While some marketing/sales tasks held less appeal, a related aspect that came across quite strongly during the interviews was the respondents' desire to personally engage with the customers.

\subsubsection{Personal engagement with customers}

Personal engagement with customer appears to be a key strategy that most respondents (12 respondents) adopted. These respondents indicated that they are strongly committed to high quality customer service and that building and maintaining good customer relationships was important to them. A number of respondents reported that growth of their business was a reflection of the customer relationships that they had built over the years. The respondents suggested that personal engagement with customers helped foster customer loyalty and also increase the customer base via word of mouth referrals. The following quotes from respondents provides some insights:

Nelson B: "we spend a lot of time in the market face-to-face with our customers [...] we are quite engaged with our customers and that's one advantage I think". The same respondent perceives that: "you have your wine on the table and have your name 
tag on or your business card there and people realize that your name is the same as the name on the bottle, it means a lot to people. So I'm not just some marketing person who works for the company, it's our story, it's our wine, you know that's us in a bottle". Martinborough B: "we find that the public come in and they want to talk to the owners because they want to hear about their passion and their story". Nelson C: "a lot of people see [...] as something special and boutique, something small that has the personal touch and I guess we just want to preserve that really”.

Waiheke B: "I think one of the most significant aspects of the growth has been not really just advertising and marketing campaigns, because we don't really spend a lot of money; we did when we started off, we put ads in magazines and stuff like that but it didn't do anything for us. The most important thing that brings us new business has been word of mouth and the growth rate that we've had from that has been incredible. And we get repeat customers in here ever since we opened, even though some of them come only once a year, they always come and they always bring new people with them. So we get two people coming, and they like it and their parents come and visit, so they bring them and their brothers and sisters, then their friends, and friends of those friends [...] it seems to be growing organically based on word of mouth and personal recommendations".

\subsubsection{Maintaining the business small-scale}

Many respondents expressed a desire for their business to remain at a smaller scale. The respondents were more concerned with the maintenance of control and other non-economic objectives rather than exploiting business potential through profit maximization.

As a means to retain control and curtail growth of business in the future, Waiheke B commented, "I think the traditional way of limiting that (growth) would be to increase price on things and I guess make it more exclusive. We're not planning to do that yet but it is possible that we might be forced to do that at some point". Martinborough A pointed out that as a small winery they face the problem of continually increasing costs and instead of increasing volumes of wine production to gain economies of scale, they address this issue by mitigating costs wherever possible. 
The respondent commented: "we cope with that [increasing costs] by doing some small things. When we don't need to use big tractors, we use small tractors; instead of mowing the grass in winter, we'll get sheep in to eat the grass [...] we've been experimenting with lightweight bottles and they cost less and they cost less to ship [...] we used to have lay-down cartons, the bottles lie down on their side; we now have upright cartons. They are less expensive to manufacture and purchase, and when we are storing them we can store them higher when they are upright and so it's more economical". Martinborough E highlighted, "it is about doing it small and beautiful and more artisan and more hand-crafted and really you know as a piece of artwork that people are passionate about and I am passionate about".

Another rationale to remain small-scale, as indicated by the respondents, was the opportunity to operate in a niche market. The respondents report that due to the relatively small size of their business, it would be difficult for them to cater to the mass market and therefore preferred to focus on a niche market. The respondents pointed out that they did not benefit from economies of scale, which was reflected in the prices of their products. Some wineries suggested that due to the high production costs of their wine, they were required to charge a premium price for their product and were targeting customers that could afford to buy their wine at that price. The wineries emphasized their focus on producing high quality wine instead of high volumes of wine.

Waiheke A: "the sort of people that we attract are the sort of people who like good wine and are prepared to pay for it and are the sort of people who like good food and are prepared to pay for it". Martinborough B: "people who have awareness of wine, people with I suppose disposable income, people who are willing to try different wine [...] usually professional because again they've got to have the income, because we are not at the low end of the market. So it's mid to high income earners, 30+, welleducated, generally well-travelled, like food and wine". Some wineries distinguished themselves further by taking the organic or biodynamic approach to wine production. Another factor highlighted by the respondents is that of personal contact with the customers and focus on excellent customer service”.

Martinborough E: "I don't want to do what everyone else is doing and in the same way because I don't want to be part of the masses [...] it's about being small 
and beautiful, it's about not being too available, it's about being rare [...] I never try to attract everyone, it's not a numbers game for me. I only try and attract the people who would actually be interested in wine". Martinborough C: "you can grow up to such a degree that you might have sort of a tag team, so I don't have to run it all everyday [...] but then there is a cost associated with that and then all of a sudden you got to sell more wine, so you got to be on the road more, so I end up robbing Peter to pay Paul, so instead of me being able to go home at 4 o'clock, I'll be in Wellington marketing or doing this and that because you then have more wine"

In describing their niche, Waiheke B commented, "In the wine industry, there is a whole range of sizes of wineries and typically there are the really big producers who tend to produce a lower cost mass market product which you'll see in the supermarket at a fairly low price and they produce a lot of it, they live on small margins large quantities. Whereas we are at the other end of the spectrum, we are pretty much boutique wine producers". Similarly, Martinborough F noted, "there's a boutique level and then there is a level up where they are 5, 6, 7, or 8 times bigger and then there is the very big people. You sort of don't want to get into the middle range because then you've got too much product to sell as a boutique supplier and you are starting to compete with the big people in the supermarkets and so on and they can always sell so much more cheaply".

Martinborough B: “we've looked at growing and realized that there is a point where you grow too big to be able to be at the high-end of the market quite so easily. If I look at some of the vineyards around here who were about our size when they started and they could control everything, they could manage everything, they could sell everything and then they grew and perhaps doubled everything that they were and then they've got more product to sell but they haven't always got the advantage of having a lower unit cost structure because they are not quite big enough. There is a sort of middle ground, I think you are better to be smaller boutique like we are or very big. I think that middle ground is perhaps the most vulnerable because you can't always get your economy of scale. So I think I'd rather be at this end of the equation where you can happily put the sign up and say we are sold out of this vintage rather than thinking that I've got so much of this that I've got no choice but to go in the supermarket and lose control of my product because I'm so big”. 
Martinborough D: "you are better off to concentrate on small volume high quality and get a good price for it". Martinborough G: "I could be making a million bottles of Sauvignon Blanc and making only a dollar per bottle, not interested, not even slightly interested. So doing what we are doing, making quality wine for a small part of the drinking market is much more of a challenge".

In describing the product's niche, Martinborough A suggests, "it appeals to only a small part of the marketplace and you are trying to appeal to people who know something about wine and who want to come and talk to you about the wine and who accept that each vintage will be different to the previous vintage". In terms of customers purchasing their product, the respondent further comments "they are going to do that because first of all it is a given that the wine is of high quality but that's not why they are going to buy it. They are going to buy it because they know the story about us and the vineyard and the winery and the bottle. So when they take their bottle of wine away and have it with their friends or family, they've got a story to tell". Martinborough F asserts this by saying, "a lot of people who buy boutique wines are really interested in the story of how it is produced and who the people are and where they live and so they are not interested in being associated with big companies". Waiheke B suggests, "for a boutique winery where large sums of your sales are actually on site here on the vineyard, you tend to be selling not just the wine itself but the story behind the wine, the ambience, the feeling for the land and that all comes as a package when people come to our location they get to experience all those elements and it's that experience they are buying, wine is a symbol of that experience in many ways".

Other wineries distinguished themselves further by taking the organic or biodynamic approach to wine production or viewed their niche in terms of personal contact with the customers and focus on excellent customer service.

\subsubsection{Addressing seasonality in business operations}

While most respondents claimed to be affected by the seasonal nature of the business, not all respondents viewed seasonality as necessarily problematic. Several respondents referred to the seasonal nature of the business as one of the key factors in 
allowing them to achieve quality of life and work-life balance objectives. Although it may difficult for respondents to achieve lifestyle objectives during busy periods (8-9 months) during the year, seasonality in business gives them the opportunity to compensate for that during the low season. Several respondents reported that they perceive the wintertime (low season) as their downtime; the opportunity to wind-down from their otherwise very hectic schedules, take time off to travel and engage in other personal activities that they enjoy. A few respondents noted that the low season gives them an opportunity to catch up on aspects of business such as infrastructure development and maintenance. Furthermore, some respondents indicated that they have a preference for diversity and challenge in their business activities and the seasonal nature of the business allows them to pursue a variety of different tasks, as each season requires a range of different things to be done. The following quotes from respondents sum this up:

Martinborough F: "I like it; you do different things at different times and each part of the year is different, different work, different challenges, different opportunities". Waiheke A: "in the summertime we work hard, in the wintertime we are open only three days a week, so I've got time to do other things". Nelson C: "there are certain times of the year when things are quite. For example, when the pruning's been finished and you are waiting for the new growth to come you've got wee bit of time". Waiheke B: "Now this is basically end of season, so it should be getting quieter now as we get into winter and then the new season will start typically in October. So we've got plenty of time until October to do infrastructure projects and we've got several of those planned, just the matter of ironing out the details".

\subsubsection{Prioritizing economic over non-economic objectives}

For some respondents, the primary focus had shifted from non-economic objectives to economic objectives. Two respondents (Nelson B and Nelson E) indicated that even though they had initially established the business for reasons associated with lifestyle, due to the increasing complexities of the business, they were required change their focus more to the economic side. Although non-economic motives were still important to them; they were no longer their priority. 
As Nelson E commented, "well people talk about lifestyle, it's a lot of hard work and I don't think there's much life [...] we've taken on more of an economic [viewpoint], that's sort of become more important to me [...]"

While this study targeted business that were run by lifestyle entrepreneurs, even so this option of abandoning lifestyle priorities still came through as a potential strategy and outcome. It is possible that many other businesses (that were not included in the sample) may have faced a similar issue with lifestyle objectives either fully abandoned or re-prioritized to a greater or lesser degree.

\subsection{Summary}

All respondents had started their businesses with lifestyle motivations. The findings above indicate that the main challenges encountered by the selected sample were issues pertaining to simultaneously growing of business, as well as their ability to achieve desired work-life balance. The challenges associated with business growth included desire to maintain hands-on control, competition in the industry, financial constraints, environmental conditions and succession of business. Furthermore, the challenges associated with work-life balance included lack of free time, blurred boundary between work life and personal life, seasonality in business and lack of business operations and organizational management issues.

All respondents had to engage in a range of strategic changes typically associated with growing the business. These included adopting strategies to grow the business operations, personal engagement with the customers, maintaining business small-scale, addressing seasonality in business operations, delegating responsibility and re-prioritizing economic over non-economic objectives. Some firms had likely shifted the balance of their orientations to maximize economic returns so that some might no longer consider them as lifestyle businesses. So far, this chapter has presented the findings of this study. A detailed discussion and interpretation of these findings are presented in the next chapter. 


\section{Chapter 5: Discussion}

\subsection{Introduction}

The previous chapter presented the analysis and key findings of my research. In this chapter, these findings are examined in conjunction with related literature. In instances where there is lack of relevant literature pertaining to the issues being addressed in the present study, the researcher has discussed these issues based on the interpretation of the findings of this study. The analysis highlighted a number of issues pertaining to lifestyle entrepreneurship, specifically relating to motivations, goals and objectives, challenges encountered and strategies employed by lifestyle entrepreneurs while running a business in the wine industry. These will be discussed in detail in the following sections of this chapter.

\subsection{Motivations and Economic Viability}

Lifestyle entrepreneurship is a complex phenomenon and the solutions available for addressing the various challenges encountered by lifestyle entrepreneurs are not straightforward. Some of the challenges encountered by lifestyle entrepreneurs may probably not be issues for classical profit and growth-seeking entrepreneurs. The supremacy of economic motivation is apparent for growth-orientated entrepreneurs; their primary objective being profit maximization (Timmons \& Spinelli, 2004). In the lifestyle entrepreneurship context, a more diverse set of objectives is relevant. This is mainly because, along with economic motivations, lifestyle entrepreneurs place a lot emphasis on the pursuit of non-economic motivations.

All respondents in this study could be categorised as opportunity-driven as opposed to necessity-driven, which is consistent with the findings of GEM (2005) who found $83 \%$ of New Zealand entrepreneurs as being opportunistic. Furthermore, where Luke et al. (2007) noted that New Zealand entrepreneurs have been viewed to prioritize lifestyle objectives by focusing on amenities such as boat, beamer (acquiring BMW cars) and bach (holiday house), in contrast, this study found that none of the 
respondents had any of the above mentioned desires, but tended to prioritize other lifestyle objectives such as living in a good location and producing high quality wine.

It was evident that all respondents had a strong passion for wine and had started their businesses to pursue this passion further. Along with the emphasis on passion, the respondents highlighted a range of lifestyle-oriented aspirations and non-economic motivations for running their businesses. These included factors such as flexibility, work-life balance, the appeal of living in a desired geographic location or for some entrepreneurs specifically living on a vineyard, and the desire for a business that affords opportunities for control, independence, personal satisfaction, sense of accomplishment and recognition of excellence. This dominance of non-economic motivations in establishing a lifestyle business has also been highlighted in a number of previous studies (e.g. Bridge et al., 2003; Kaplan, 2003; Kaplan \& Warren, 2007; Lashley \& Rowson, 2010; Marcketti et al., 2006).

In addition to non-economic motivations, it was evident that economic motivations were also of importance to all respondents. The importance of economic motivations in lifestyle business operations has been recognized in earlier studies (e.g. Carsrud \& Brannback, 2011; Getz \& Carlsen, 2000; Rimmington et al., 1999). Although running a profitable business was a concern for all respondents, they were not necessarily focused on profit maximization. This finding supports previous research by Lashley and Rowson (2010) who found that lifestyle entrepreneurs were more concerned with issues pertaining to control and location as opposed to exploiting the full business potential in terms of financial profits. The respondents expressed that they were aiming to earn enough income to sustain the business and support their chosen lifestyle, which is consistent with the findings of Kuratko and Hodgetts (1998) and Rimmington et al. (1999), as illustrated in the literature review.

This pursuit of economic and non-economic motivations simultaneously increases the complexity of running the business in terms of the challenges that lifestyle entrepreneurs encounter. Some of these complexities are discussed below.

While previous studies have pointed out the appeal for lifestyle entrepreneurs to live in a desired location (Peters et al., 2009; Stone \& Stubbs, 2007), they have not fully addressed the complexities associated with such a desire. In this study, 6 respondents pointed out that the ability to live and work on the vineyard appealed to 
them. However, these respondents also raised the issues that arise with living and working at the same place. For these respondents, the boundaries between their worklife and personal-life appears to be blurred. They pointed out that it was very difficult to get away from work and that they found themselves constantly working. This potentially contradicts the stereotypical image of 'lifestyle' being an entirely synergistic combination of work and passion.

For many 10 respondents in this study, spending more time with family and working with family were important considerations in their decision to embark on the journey of lifestyle entrepreneurship and for some an ongoing motivating factor in running the businesses. However, while these respondents are successful in achieving those objectives in one way, they might be compromised in another. For example, most of the time spent with the family members seems to be associated with work. All respondents highlighted that they worked very long hours and due to the demands associated with work, and there seems to be very little downtime or time left to pursue other activities of personal interest. This might conflict with the notion of work-life balance that the respondents pointed out as being important to them. Examples included an inability to schedule holidays during peak season and having to work most weekends of the year.

All respondents also expressed their desire for overall control and hands-on involvement in the key aspects of business, which potentially conflicts with the growth of the business. As a result many of the entrepreneurs interviewed emphasized that they wanted to maintain their business small-scale. Furthermore, growth of the business usually entails delegating responsibilities or increased workload on part of the entrepreneur. For example, out of the 13 respondents involved in wine production, 3 respondents produced their own wine, whereas the remaining 10 respondents employed a winemaker but were still actively involved in the wine production process and closely monitored and worked with the winemaker. This indicates that even though the respondents employed specialized staff, they still had the desire to be involved in those aspects of the business.

In this study, while both economic and non-economic motivations, goals and objectives were important to the respondents, it was found that they struggled to strike a balance between them. The central issue for lifestyle entrepreneurs appears to be the 
challenge of maintaining an economically-sound business while simultaneously satisfying other lifestyle objectives sufficiently. This contrasts with studies by LeeRoss (2012) and Peters et al. (2009) in the literature review that characterised lifestyle

businesses as dramatically different because economic objectives were not only primary pursuit. The lifestyle businesses studied here could not ignore economic imperatives and all had to adapt their strategies to ensure viability. Similar to growthoriented businesses, lifestyle businesses also need to make sufficient income in order to ensure survival and long-term sustainability of the business. One such measure to address the issue of viability was identified as growing of the business.

It has been argued in the literature that growth in business may be instigated due to necessity, or because the entrepreneur has personal motivations in doing so (Marchant \& Mottiar, 2011). In this study, the majority of the respondents reported that they were required to grow the business mainly due to economic pressures (e.g., increase in competition and fluctuation in demand). The entrepreneurs here have undertaken varying levels of business growth to address the issue of economic viability. However, few respondents articulated a desire to grow the business but within certain limits. Typically, growth was controlled and capped to achieve personal and/or family-oriented objectives, mainly pertaining to lifestyle. For example, a number of respondents expressed their desire for hands-on involvement in the various business operations, which might be difficult to achieve if the business grew significantly. For example, Waiheke B highlighted that it becomes increasingly difficult to maintain a high level of personalized service as the business grows bigger. The next section describes the various factors that influenced the growth of lifestyle businesses interviewed in this study.

\subsection{Factors influencing business growth}

An increase in competition was a major factor that had instigated the need to grow the businesses. Like profit and growth-oriented businesses, lifestyle entrepreneurs also face the issue competition. In total, 6 respondents indicated that they were forced to pursue growth due to the increase in competition, which adversely affected survival prospects of their business. These respondents frequently had started their businesses when there was little competition in the industry and the demand for 
wine far exceeded supply. The respondents reported that it was much easier in those times to achieve lifestyle objectives and sideline concerns about growth of business. However, the dramatic rise in the number of wineries, and increase in competition forced many respondents purposefully grow their businesses to offset the increasing price competition as supply began to exceed demand.

With the increase in the number of wine producers, customers have more choices. Therefore, there is also increasing pressure on wineries to focus their efforts on marketing their products, even though they may not necessarily enjoy that aspect of business very much. If the respondents did not focus on the marketing side of business, it often proved very difficult to sell their wine. For example, Martinborough D points out that producing high quality wine is not enough anymore; due to the economic downturn customers are becoming more conscious of how they spend their money and price point is becoming an important issue.

The issues of competition and competitive advantage in business have received extensive attention by scholars in recent years (Barney, 1997; Barney, 1995; Hanson, Dowling, Hitt, Ireland, \& Hoskisson, 2008; Kirzner, 1978; Porter, 1980). These authors point out the need to take competitive actions into account in order to cope with the challenges presented by discontinuous environmental changes. Many industries, including the wine industry, are influenced by increasing globalization and many businesses find themselves competing in more volatile and unpredictable business environments. Such organizations are required to be strategically flexible and adaptable if they hope to survive in the ever-changing business environment (Hanson et al., 2008).

Thus, it is apparent that lifestyle entrepreneurship is dynamic in nature. The issue of capital constraints adds further complexities to the growth of business. The availability of finance and access to that finance is critical to the start-up and consequent performance of any business. For the majority of the respondents, there was heavy reliance on family and personal savings to finance their businesses. Formal sources of capital - such as bank loans or the use of finance companies - played relatively minor roles. The main reason for not seeking outside help, as indicated by the respondents, was not wanting to be in debt. However, these formal channels were used by a few respondents in conjunction with personal savings. Similarly, Lee-Ross 
(2012) noted that family businesses tend to be averse to debt, which is likely to affect the growth potential of the firm.

Most respondents in the present study indicated that the growth undertaken in their businesses was a gradual process and that one of the reasons for this was financial constraints. After the initial establishment of the business, the entrepreneurs were mainly relying on internally-generated profits to sustain their businesses. Similarly with growth, once the entrepreneurs had invested in a particular aspect of business (e.g. cellar door), the entrepreneurs needed to recoup the investment through profits in order to have enough financial resources to pursue further growth.

Nelson A emphasized that growth in the wine industry is very capital intensive, as many of the business operations require a lot of financial investment. This was asserted by 8 other respondents. Furthermore, many respondents pointed out that the return on investment happens gradually over a long period of time. In addition, 4 respondents called attention to the issue that their businesses were self-sustaining but they did not make enough profits to have surplus left over to invest in growth and expansion.

Martinborough B pointed out that there was not a lot of help available from the New Zealand government in terms of export of wine or subsidies in viticulture; which tends to put New Zealand wineries under a lot of financial strain. Furthermore, 3 respondents brought to light the difficulty of attaining loans from banks. The banks were vary to lend money to the vineyards mainly because in recent years a lot of vineyards had borrowed huge sums of money and some had experienced significant financial problems.

Uncertainties associated with the natural environment (bad weather, changes in climatic conditions) were observed to be another factor affecting growth. Grapegrowing is heavily reliant on weather conditions and a bad season could mean huge financial losses for the business. Overall, 5 respondents reported instances where bad weather had severely hampered their business operations. Therefore, the respondents had to be cautious of potential financial losses and factor in issues such as bad weather and changes in climatic conditions when considering growth of business and capital outlays. 
Further illustrations of wanting to keep the business smaller-scale were identified among all respondents. This was mainly in order to continue to operate in the 'niche market'. The respondents indicated that they did not have the desire, nor the resources, to grow their business large-scale. Also, all respondents expressed their concern for not wanting to be stuck in the middle ground, where they would be too big to operate in the niche market but would not be big enough to benefit from economies of scale. All respondents were focused on producing high-quality wine and targeted the high-end consumer market. This is consistent with the findings of Ateljevic and Doorne (2000), who argue that many lifestyle entrepreneurs in the tourism industry of New Zealand opt to 'stay within the fence' (consciously rejecting economic and business growth opportunities) in order to preserve their 'niche' market position.

\subsection{Directions of growth}

Another noteworthy finding was that even though existing literature describes lifestyle entrepreneurs as lacking a growth orientation (e.g. Lee-Ross, 2012; Marchant \& Mottiar, 2011; Peters et al., 2009), this was not necessarily the case for the respondents interviewed for this study. All respondents had achieved some level of growth since the inception of their businesses; some more than others. The management strategies undertaken to address growth appeared to be emergent in nature, with respondents making changes in their businesses as and when deemed necessary. Very few respondents reported that they followed a formal business plan around growth.

Furthermore, it was found that the respondents made attempts to address multiple and conflicting objectives simultaneously. No single strategy (from Ansoff's matrix) seemed to lead to a full harmonious balance and all strategies seemed to compromise one or the other of the sub-objectives associated with lifestyle. Some emergent strategies even led to growth and business success that forced the primacy of lifestyle objectives to be re-evaluated. Thus, it seems reasonable that the lifestyle entrepreneurs choose the strategies that suit them best depending on their goals and objectives.

In this study, growth occurred as a result of various strategies. Using Ansoff's 
(1965) model as described in the literature review, these can be broadly classified as follows: market penetration (achieved through growing more grapes and increased marketing efforts), product development (introduced new grape varietals), market development (wine sales to more geographical locations: domestic/international) and diversification (restaurant/café operations, accommodation services). All respondents adopted a combination of the above strategies. Of these, 8 respondents had started their businesses with a focus on the domestic market and later extended their wine sales to international markets.

The main reason for adopting a combination of the above mentioned strategies, as indicated by 7 respondents, was that they did not want to put "all their eggs in one basket". The rationale behind this was to spread the risks. For example, if the international market was not performing well temporarily due to high exchange rates, it is possible to receive income from the domestic market. A downside of this approach, however, might be that the entrepreneur's attention needs to be diverted in multiple areas rather than focusing on a narrower set of activities. Therefore, it is likely to increase the workload of the entrepreneur and may also require the entrepreneur to invest more time in the business.

The respondents sold their products through various distribution channels including cellar door sales, international wine exports, domestic sales (local/nationwide restaurants, liquor/wine stores, mail delivery) and on-site restaurant/café. All respondents reported that they sold majority of their wine in the domestic market; with 3 respondents stating that they were too small to be engaging with the international market and therefore focused solely on the domestic market. These 3 respondents indicated that they were content with the size of their operations and had no intention to extend to the international market.

Also, for the remaining 10 respondents who were engaged in wine production, scale of operations was an important factor directing their focus on the domestic market. In addition, as pointed out by 4 respondents, establishing international markets may require huge amounts of financial investments in terms of increasing the scale of operations (grape-growing and wine-making) and also costs associated with marketing and distribution of their products. Furthermore, all these respondents indicated that they enjoyed the aspect of personal engagement with the customers. Therefore, it is 
more likely for them to invest their resources in operations such as cellar door and restaurant/café; where they can sell their product by a means that brings more enjoyment to them.

\subsection{Business Growth and Lifestyle Orientation}

The combination of forces affecting change in the industry required the lifestyle entrepreneurs to rethink their lifestyle strategies in fundamental ways. Although many of the interviewees (12 respondents) indicated that running a wine business involved more work than they initially anticipated, it did not completely negate the lifestyle benefits they sought from the business. These respondents reported that since they were engaged in work aligned with their personal passions, they did not view investing long hours in their businesses as a problem. This was mainly because the respondents perceived lifestyle as a broader concept than just the amount of work involved; including the personal satisfaction gained from producing a high quality product, receiving recognition for excellence (products and services), having the independence to run their own business, working alongside family members, and living in a desired location.

Burns (2007) argues that while lifestyle entrepreneurs are not primarily motivated by business growth, some of them can incur significant growth which may have an influence on their ability to maintain their lifestyle status. A similar issue was encountered by 2 respondents (Nelson B and Nelson E) in this study. These respondents indicated that they had started their business with lifestyle objectives but they had gradually changed their approach to focus on growth and maximizing economic returns. Both of these respondents had established their business when there was little competition in the market and there was high demand for wine.

For Nelson B, the change in orientation was mainly due to enjoying high level of success in the market. The respondent had gained a reputation for producing high quality wine, in both the domestic and international markets. High demand for their products had resulted in the entrepreneur growing the business at a phenomenal rate. For Nelson E, it was mainly factors relating to burnout in the struggle to accomplish lifestyle objectives while running the business economically viable. The respondent 
highlighted the fact of having to compete with things beyond their control (e.g. bad weather conditions and economic downturn); and thereby having experienced a tough time in the industry for a few years. In the process of ensuring viability, the respondent was required to undertake significant growth. These findings are corroborated by Marchant and Mottiar (2011) who, in their study on lifestyle entrepreneurs engaged in surf tourism in Ireland, found that some lifestyle entrepreneurs in their sample had relegated their lifestyle motivations in response to business growth.

Both the respondents here highlighted that attaining lifestyle objectives (hands-on involvement in various business operations; personal engagement with customers) were still important to them but they were now prioritized as secondary to economic objectives. Both were now actively seeking growth of business mainly by trying to establish new export markets. It is thus apparent that entrepreneurial motivations are not static and can change considerably. Reprioritization is, thus, another strategy that lifestyle entrepreneurs may pursue to manage the challenges they face.

\subsection{Addressing Work-life Balance}

While business growth may help address economic challenges that these entrepreneurs face, the data here suggest that it is likely to exacerbate other challenges. A number of respondents reported the difficulty of being able to recoup enough money from the profits of the business. Owing to such financial constraints, some of the entrepreneurs were not able to hire additional staff, and therefore were burdened with more workload.

It is likely that in the process of growing the business, some of their lifestyle objectives may be compromised. For example, the entrepreneur may be required to: spend more time working, delegate tasks, and perform tasks that they don't particularly enjoy (e.g. sales, marketing). Each of these aspects conflicts to a certain extent with their ability to achieve desired lifestyle. Spending excessive amount of time at work is likely to conflict with the ability to achieve work-life balance, delegating tasks is likely to conflict with their desire to retain control and performing 
tasks that they don't enjoy is likely to conflict with their desire to do work that they are passionate about.

While 12 respondents pointed out that they do not particularly enjoy the sales/marketing aspect of the business, it was interesting to find that they were still quite passionate about personally engaging with the customers. The respondents generally indicated that the interactions with customers was a pleasure rather than a chore. For example, these 12 respondents indicated that they enjoyed one part of the sales aspect (customer interactions at the cellar door) but did not enjoy the marketing side of the business. Increasing marketing efforts could help them better promote their brand and reach out to a wider audience. Overall, 9 respondents mainly seemed to rely on word of mouth advertising; perhaps indicating an avoidance of formal marketing. It is possible that these respondents may spend a lot of time doing things that they do enjoy, and neglect aspects that they don't. Consequently, the aspects that are neglected may suffer, which could hamper the overall performance of the business. Thus, financial pressures faced by entrepreneurs, and the needs for business growth, requires these entrepreneurs to engage in activities that they may not like but need to do either themselves or via delegation (which again runs counter to their desire for control).

Growth of a business may also require the entrepreneur to possess strategic and tactical skills and abilities. Consistent with the findings of Lashley and Rowson (2009), the majority (11 respondents) of the lifestyle entrepreneurs interviewed in this study lacked a qualification and/or previous experience related to the industry. Only 3 respondents indicated that they had either a qualification in viticulture or some sort of work experience in the wine industry, prior to establishing their businesses.

On the whole, 8 respondents indicated that, with the growth of their businesses, they sought to hone their business capabilities, particularly in regards to marketing, salesmanship, interpersonal relationships and product development. This was mainly achieved by the respondents taking steps to acquire additional skills or in some cases by delegation. As the business grows, the respondents are also required to sell more of their products/services. As they are trying to reach out to more customers, they might need to strengthen other core capabilities such as product development and marketing in order to increase the appeal of their products/services. 
The respondents also had to deal with seasonality in both wine production (grape growing and wine production) as well as consumption (cellar door sales and restaurant/café visitation). All participating wineries were impacted by the seasonality of production (grape growing and wine production), while a few were also impacted by the seasonality of consumption (seasonality in visitation at cellar door; restaurant/café; accommodation). An interesting finding that emerged was that seasonality was perceived by the respondents both as a challenge as well as a means to overcome the issue of work-life balance. For example, due to the agricultural aspect of vineyard operations, the respondents were required to work on several public holidays, (e.g. Christmas, New Year's Eve, etc.) made it difficult to spend time with family and friends during their special occasions. Moreover, they were also required to work very long hours during busy times (usually 8-9 months of a year). However, the low season was perceived by 9 respondents as an opportunity to address issues relating to work-life balance. These respondents suggested that they would usually take time off work to travel and pursue other activities of personal interest.

The responses of many respondents illustrated the tensions created by the paradox of wanting work-life balance that entrepreneurship can provide; that is, although entrepreneurs may have greater control over their working lives they often have to work harder. All respondents made reference to the long hours they invested in their businesses. Due to the seasonal nature of the business, the entrepreneurs were constrained in terms of when they could take time off work. Many times, they could not take holidays at times that they would have liked (e.g. Christmas). All respondents indicated that during peak season it was not uncommon for them to work from early morning till late at night.

Marcketti et al. (2006) found a co-relation between the enhancement of the entrepreneurs' quality of life and the entrepreneurial venture, and further suggested that the entrepreneurial venture is also likely to enhance the quality of life of other stakeholders. Similarly, this study found that lifestyle entrepreneurship was perceived to provide enhanced quality of life to the entrepreneurs, their families and the customers. Many respondents indicated that the benefits of living in the chosen location contributed to the enhancement of their quality of life and the quality of life of their families. Furthermore, these respondents also pointed out that they extend 
quality of life benefits to their customers by sharing their personal passion and offering them high quality products and services.

\subsection{Summary}

In this chapter, the key findings of the present study have been discussed in conjunction with related literature. The investigation into the various issues influencing lifestyle entrepreneurship in the wine industry of New Zealand provided mixed results. Many of the findings mirror the suggestions made by previous studies, however, some new findings have also been highlighted. The next chapter draws together the conclusions of this study. 


\section{Chapter 6: Conclusions}

\section{1: Thesis Summary}

The purpose of this research was to shed light on some fundamental issues pertaining to lifestyle entrepreneurship by attempting to answer the following research questions: 1) what are the challenges encountered by lifestyle entrepreneurs in their pursuit of economic and non-economic motives simultaneously, and 2) What strategies are employed by these entrepreneurs to cope with these challenges. In so doing, a qualitative approach was adopted which provided the researcher with an indepth and extensive understanding of the various business practices adopted by lifestyle entrepreneurs in the wine industry of New Zealand. Based on the analysis and discussion of key findings, several conclusions can be drawn about the dynamics of lifestyle entrepreneurship. This chapter starts by summarizing these conclusions. It then continues by suggesting avenues for future research. Following this, limitations and implications of this research are discussed.

Entrepreneurial endeavours are significantly influenced by motivations of the entrepreneurs. For many entrepreneurs, lifestyle motivations are inextricably bound up in business endeavours; shaping how the entrepreneur approaches business but also being influenced by the nature of the industry and evolution of the business the entrepreneur runs (e.g. Bridge et al., 2003; Kaplan \& Warren, 2007; Lashley \& Rowson, 2010). The establishment of lifestyle businesses is dominantly associated with non-economic motivations. However, as demonstrated here, economic motivations also play an important role in such businesses as they provide a means to sustain the business and chosen lifestyle of the entrepreneur.

As highlighted in the previous two chapters, lifestyle entrepreneurs face numerous challenges in the process of running their businesses. Some of these challenges need to be addressed on an ongoing basis. For example, due to the everchanging market conditions and volatile business environment, lifestyle entrepreneurs are likely to encounter significant issues pertaining the viability of their businesses. In order to ensure viability and to cope with increasing economic pressures (e.g. increase 
in competition and fluctuation in demand), lifestyle entrepreneurs may be required to undertake business growth.

The growth of their business, though, poses several complexities. It frequently conflicts with the entrepreneurs' desire to maintain hands-on involvement in the various business operations, since the entrepreneur may need to delegate more responsibilities. In circumstances where the entrepreneur lacks the financial resources to employ additional staff, the entrepreneurs may need to invest more time in the business leading to the increased workload. Furthermore, due to the capital-intensive nature of the wine industry, business growth is also constrained due to lack of availability of financial resources. Since lifestyle entrepreneurs are heavily reliant on informal sources of financing (personal and family savings), growth of the business becomes a gradual process. In addition, lifestyle entrepreneurs also have to deal with issues pertaining to organisational management that accompany business growth (e.g. hone business capabilities).

Like profit-oriented entrepreneurs, lifestyle entrepreneurs also encounter the challenges posed by the external business environment. They might be required to adapt their strategies to cope with the changes in market conditions, increasing competition in the industry, and changing consumer preferences. There is a great need for flexibility and adaptability in the strategies employed by lifestyle entrepreneurs.

In sum, the findings of this study suggest that lifestyle entrepreneurs in the wine industry face multiple conflicting objectives. They need to be economically viable to survive, and, in order to ensure viability of the business, they need to grow and develop their businesses. Growth may lead them to compromise some lifestyle related aspects. For example, they may be required to do aspects of work they don't particularly enjoy (e.g. marketing). Also, they are required to dedicate very long hours to working in their businesses. This leaves them with very little time to pursue other activities of personal interest. It may also have an adverse impact on the personal relationships with family and friends, since the entrepreneurs might not have enough free time left to spend with them, thus, conflicting with the notion of work-life balance. Overall, the challenges of running a business for lifestyle entrepreneurs may be more complex than other entrepreneurs because their lifestyle motivations create additional challenges and conflicts. 


\subsection{Avenues for Future Research}

The vast majority of the existing literature on lifestyle entrepreneurship predominantly focuses on the hospitality and tourism sectors. Therefore, many of the issues attributed to lifestyle-oriented businesses may be context specific to hospitality and tourism. This research has taken the focus to the wine industry; future research could examine relevant issues pertaining to lifestyle entrepreneurship focusing on other industries or across different industry sectors. Furthermore, this research looked at a particular segment of lifestyle entrepreneurs, namely family businesses. Future research could expand the scope of this study by incorporating other business operations with lifestyle orientations such as sole-proprietorship, partnerships, joint ventures, etc.

Due to the negative connotations attached to the term 'lifestyle' as a type of business (e.g. lifestyle businesses are not 'serious' businesses), it is likely many businesses may shy away from the term, even though their businesses may embody these characteristics. A total of 25 wineries were contacted in the three regions, from which 14 agreed to participate in this study. As discussed earlier, a few wineries from the Nelson region initially refused to participate in this study because they did not consider themselves lifestyle businesses but instead as serious businesses, even though the characteristics of their businesses, as described on their individual websites indicated lifestyle-orientation. This issue was addressed by eliminating the term 'lifestyle' from the title of the research information sheet. Future researchers could be careful in using the term 'lifestyle' when approaching lifestyle entrepreneurs, as some people may not like to be referred to as lifestyle entrepreneurs even though their businesses may embody those characteristics.

The findings from this study illuminate the fact that entrepreneurial motivations are not static and are likely to change over time. Out of the 14 - lifestyle entrepreneurs interviewed, 12 continue to fulfil the typical characteristics of lifestyle entrepreneurship. For example, these respondents continue to: express their passion for wine and wine-making, enjoy living in the chosen location, retain hands-on involvement in many business operations, and derive personal satisfaction from producing high quality products. However, these respondents need to find a dynamic 
balance across these objectives. The remaining 2 respondents have shifted their primary focus towards economic objectives. The present research examined the concerns of lifestyle entrepreneurs in one point in time. Future research into lifestyle business might employ longitudinal data, so as to examine how the business motivations and strategies of lifestyle entrepreneurs change over time.

\subsection{Limitations}

Like many other studies, this research also has some limitations. It is prudent to acknowledge the limitations of this research so that the findings can be interpreted meaningfully and future research can consider these. Limitations relating to the research methods were discussed in Section 3.10, which included the potential bias associated with the interpretative process in adopting a qualitative approach, the representativeness of sample and generalizability of the findings. Further limitations of this study are discussed below:

Firstly, the study was aimed at looking at entrepreneurs with lifestyle orientation in their businesses. Broadly, this criterion was met. However, at the time the interviews were conducted, two respondents had shifted their focus towards prioritizing economic objectives. Even though lifestyle-oriented goals were still important to them, they were now secondary to economic objectives. Thus, sample selection may have a big influence on the findings, from self-selection as occurred when initially contacting interviewees to participate in this research project.

Secondly, the research was also limited by the amount of information the participants were willing to share. The respondents were not willing to provide specific details about their businesses (e.g. how much profits/loss the business was making). Those details were more generally provided (e.g. the business is self-sustaining). This made it difficult to study the data quantitatively in terms of the number of hours these entrepreneurs invested in their businesses and whether they were actually maintaining financial viability.

Finally, while the complex challenges involving the balance between noneconomic and economic objectives appear relatively generalizable to other contexts, the specific activities within Ansoff's framework are: naturally contextually 
embedded in the wine industry. However, the finding that these strategies themselves tend to lead to additional work-life balance issues is likely to occur no matter which industry is analyzed.

\subsection{Managerial Implications}

The findings of the present study should be beneficial to those who are considering the pursuit of lifestyle objectives via entrepreneurship in the wine industry and more broadly to those who are in the pursuit of lifestyle-oriented businesses. This study has provided some insight into the various challenges encountered by lifestyle entrepreneurs in the wine industry and also shed light on how these entrepreneurs attempt to address such challenges. Aspiring lifestyle entrepreneurs may benefit from the awareness of these key issues before embarking on their journey of lifestyle entrepreneurship. Furthermore, established lifestyle entrepreneurs can also benefit from the insights and experiences of other entrepreneurs in the similar position.

An important aspect to consider in relation to lifestyle entrepreneurship is that lifestyle businesses should also be viewed as serious businesses. Such businesses cannot survive if they do not operate in a fiscally responsible manner. All the businesses interviewed, relied on recouping their investments through profits in order to be able to survive. The problems encountered by these lifestyle entrepreneurs in the wine industry are complex and not easily resolved. There does not appear to be a single strategy that allows for key lifestyle objectives to be achieved that does not simultaneously affect other objectives in a negative way. For example, if the lifestyle entrepreneur in the wine industry diversifies the business to provide restaurant/café facilities, such growth is generally accompanied by either delegation of responsibilities or increased workload on part of the entrepreneur. These decisions, in turn, then compromise other lifestyle objectives such as desire for control or work-life balance.

Although lifestyle entrepreneurs in this study were required to grow their businesses to ensure viability of their businesses, they tended to choose to remain relatively small-scale. This can work somewhat against their need to grow to sustain economic viability. Lifestyle entrepreneurs may at times, though, stimulate significant 
demand and would either need to manage away such growth or re-prioritize their primary objectives to focus on maximizing economic returns.

\subsection{Concluding Statement}

This study has offered insights into important issues relevant to the phenomenon of lifestyle entrepreneurship, and more broadly, to the concept of entrepreneurship. It contributes to our understanding of business practices in smallscale lifestyle-orientated wineries. While most of the existing research addressing the phenomenon of lifestyle entrepreneurship has been predominantly conducted in the context of hospitality and tourism, this study investigates lifestyle entrepreneurship in the context of the New Zealand wine industry and confirms the existence of lifestyle entrepreneurs in this industry. Some of the findings appear to be generalizable to other contexts.

Overall, it is apparent that lifestyle entrepreneurship is a complex phenomenon. Maintaining viability in their businesses while satisfying both economic and noneconomic motivations simultaneously seems to be a formidable challenge for lifestyle entrepreneurs. While existing literature has argued the lack of growth orientation in lifestyle businesses, this study illustrated the need for a certain amount of growth in order to sustain lifestyle businesses and ensure long-term viability of these businesses. It is hoped that these findings will aid and inspire researchers to consider this area in further detail in the future. 


\section{References}

Alexander, N. \& McKenna, A. (1999). Rural tourism in the heart of England. International Contemporary Hospitality Management, 10(5), 203-207.

Andersson, T., Carlsen, J., \& Getz, D. (2002). Family business goals in the tourism and hospitality sector: Case studies and cross-case analysis from Australia, Canada, and Sweden. Family Business Review, 15, 89-106.

Ansoff, H. I. (1965). Corporate strategy: An analytic approach to business policy for growth and expansion. New York: McGraw-Hill Book.

Ateljevic, I., \& Doorne, S. (2000). Staying within the fence: Lifestyle entrepreneurship in tourism. Journal of Sustainable Tourism, 8(5), 378-392.

Barkham, R., Gudgin, G., Hart, M. \& Hanvey, E. (1996). The Determinants of Small Firm Growth. London: Jessica Kingsley.

Barney, J. (1995). Looking inside for competitive advantage. Academy of Management Executive, 9(4), 49-61.

Barney, J. B. (1997). Gaining and Sustaining Competitive Advantage. Reading, Massachusetts: Addison-Wesley.

Barnett, F. \& Barnet, S. (1988). Working Together: Entrepreneurial Couples. Berkeley, California: Ten Speed Press.

Barnett, F. \& Barnet, S. (1989). Entrepreneurial couples. The Futurist, 23(3), 50.

Baumol, W. J. (1968). Entrepreneurship in economic theory. The American Economic Review, Papers and Proceedings of the Eightieth Annual Meeting of the American Economic Association, 58(2), 64-71.

Bensemann, J., \& Hall, C. M. (2010). Copreneurship in rural tourism: exploring women's experiences. International Journal of Gender and Entrepreneurship, 2(3), 228-244. 
Bridge, S., O’Neill, K., \& Cromie, S. (2003). Understanding enterprise, entrepreneurship and small business ( $2^{\text {nd }}$ ed.). New York: Palgrave Macmillan.

Bull, I. and Willard, G. E. (1993). Towards a theory of entrepreneurship. Journal of Business Venturing, 84(3), 183-195.

Burns, P. (2007). Entrepreneurship and small business (2 ${ }^{\text {nd }}$ ed.). New York: Palgrave Macmillan.

Bygrave, W. D. \& Hofer, C. W. (1991). Theorizing about entrepreneurship. Entrepreneurship Theory and Practice, 16(2), 13-22.

Cardon, M. S., Wincent, J., Singh, J., \& Drnovsek, M. (2009). The nature and experience of entrepreneurial passion. Academy of Management Review, 34(3), 511-532.

Cardon, M. S., Zietsma, C., Saparito, P., Matherne, B. P., \& Davis, C. (2005). A tale of passion: New insights into entrepreneurship from a parenthood metaphor. Journal of Business Venturing, 20, 23-45.

Carland, J. W. Hoy, F., Boulton, W. R. \& Carland J. A. C. (1984). Differentiating entrepreneurs from small business owners: a conceptualization. Academy of Management Review, 9(2), 354-359.

Carsrud, A., \& Brannback, M. (2011). Entrepreneurial motivations: What do we still need to know? Journal of Small Business Management, 49(1), 9-26.

Casson, M. (1982). The entrepreneur: An economic theory. Cheltenham, UK: Edward Elgar.

Cavana, R. Y., Delahaye, B. L., \& Sekaran, U. (2001). Applied business research: Qualitative and quantitative methods. Milton, Qld: Wiley.

Chaganti, R., \& Schneer, J. A. (1994). A study of the impact of owner's mode of entry on venture performance and management patterns. Journal of Business Venturing, 9, 243-260. 
Chaudhuri, R., Datta, S. K., \& Ghosh, S. (2012). When it comes to motivation of entrepreneurs - a few issues. Productivity, 52(4), 208-215.

Chua, J. H., Chrisman, J. J. \& Sharma, P. (1999). Defining the family business by behaviour. Entrepreneurship Theory and Practice, 23, 19-40.

Clark, S. C. (2000). Work/family border theory: A new theory of work/family balance. Human Relations, 53, 747-770.

Cliff, J. E. (1998). Does one size fit all? Exploring the relationship between attitudes towards growth, gender, and business size. Journal of Business Venturing, 13, $523-542$.

Collinson, E. \& Shaw, E. (2001). Entrepreneurial marketing- a historical perspective on development and practice. Management Decision, 39(9), 761-766.

Conger, M. (2012). The role of personal values in social entrepreneurship. In J. Kickul and S. Bacq (Eds.), Patterns in social entrepreneurship research (pp. 87-109). London: Edward Elgar Publishing Ltd.

Cooper, A. C., \& Artz, K. W. (1995). Determinants of satisfaction for entrepreneurs. Journal of Business Venturing, 10, 439-457.

Cooper, A. C., \& Dunkelberg, W. C. (1986). Entrepreneurship and paths to business ownership. Strategic Management Journal, 7, 53-68.

Creswell, J.W. (1998). Qualitative inquiry and research design: Choosing among five traditions. Thousand Oaks, CA: Sage.

Cromie, S. (1987). Motivations of aspiring male and female entrepreneurs. Journal of Occupational Behaviour, 8, 251-261.

Cunningham, J. B. \& Lischeron, J. (1991). Defining entrepreneurship. Journal of Small Business Management, 29(1), 45-61.

Dawson, D., Joanna, F., \& Cohen, D. A. (2011). Seasonality and the lifestyle "conundrum": An analysis of lifestyle entrepreneurship in wine tourism regions. Asia Pacific Journal of Tourism Research, 16(5), 551-572. 
Deakins, D., \& Freel, M. (2006). Entrepreneurship and small firms. (4 ${ }^{\text {th }}$ ed.). London: McGraw Hill.

Dewhurst, P., \& Horobin, H. (1998). Small business owners. In R. Thomas (Ed.), The Management of Small Tourism and Hospitality Firms (pp. 19-38). London: Cassell.

Di Domenico (2005). Producing hospitality, consuming lifestyles: Lifestyle entrepreneurship in urban Scotland. In E. Jones, \& C. Haven-Tang (Eds.), Tourism SMEs, service quality and destination competitiveness (pp. 109-122). Cambridge, MA: CABI Pub.

Easterby-Smith, M., Thorpe, R., \& Jackson, P. R. (2008). Management research $\left(^{\text {rd }}\right.$ ed.). London: SAGE.

Eckhardt, J. T., \& Shane, S. A. (2003). Opportunities and entrepreneurship. Journal of Management, 29(3), 333-349.

Egoz, S., Bowring, J., \& Perkins, H. (2006). Making a mess in the countryside: Organic farming and the threats to sense of place. Landscape Journal, 25(1), 54-66.

Eikhof, D. R., \& Haunschild, A. (2006). Lifestyle meets market: Bohemian entrepreneurs in creative industries. Creative and Innovation Management, 15(3), 234-241.

Eisenhardt, K. M. (1989). Building theories from case study research. Academy of Mangement Review, 14(4), 532-550.

Eriksson, P., \& Kovalainen (2008). Qualitative methods in business research. London: SAGE.

Esterberg, K. G. (2002). Qualitative methods in social research. Boston: McGrawHill.

Fitzgerald, M., \& Muske, G. (2002). Copreneurs: An exploration and comparison to other family businesses. Family Business Review, 15(1), 1-16. 
Flick, U. (1998). An introduction to qualitative research. London: Sage.

Frederick, H. (2004). The Unitec Global Entrepreneurship Monitor 2003/04: Toward high growth enterprise in New Zealand. Unitech New Zealand's Centre for Innovation and Entrepreneurship Research Report Series, 3(1). Auckland: Unitec New Zealand.

Frederick, H., \& Chittock, G. (2006). The global entrepreneurship monitor Aotearoa New Zealand. 2005 Executive Report.

Gartner, W. B. (1990). What are we talking about when we talk about entrepreneurship? Journal of Business Venturing, 5, 15-28.

Getz, D., \& Carlsen, J. (2000). Characteristics and goals of family and owner-operated businesses in the rural tourism and hospitality sectors. Tourism Management, $21,547-560$.

Getz, D., \& Carlsen, J. (2005). Family business in tourism: State of the art. Annals of Tourism Research, 32(1), 237-258.

Getz, D., Carlsen, J., \& Morrison, A. (2004). The Family Business in Tourism and Hospitality. Wallingford: CAB International.

Glancey, K., \& Pettigrew, M. (1997). Entrepreneurship in the small hotel sector. International Journal of Contemporary Hospitality Management, 9(1), 2124.

Goulding, P. J., Baum, T. G., \& Morrison, A. J. (2005). Seasonal trading and lifestyle motivation: experiences of small tourism businesses in Scotland. Journal of Quality Assurance in Hospitality and Tourism, 5(2-4), 209-238.

Gray, C. (2002). Entrepreneurship, resistance to change and growth in small firms. Journal of Small Business and Enterprise Development, 9(1), 61-72.

Hall, C. M., \& Rusher, K. (2004). Risky lifestyles? Entrepreneurial characteristics of the New Zealand bed and breakfast sector. In: R. Thomas (Ed.), Small firms in tourism: International perspectives (pp. 84-97). Amsterdam: Elsevier. 
Hamilton, B. H. (2000). Does entrepreneurship pay? An empirical analysis of the returns to self-employment. Journal of Political Economy, 108, 604-631.

Hanson, D., Dowling, P., Hitt, M. A., Ireland, R. D., and Hoskisson, R. E. (2008). Strategic Management: Competitiveness and Globalization. South Melbourne, Victoria, Australia: Thomson.

Hebert, R. F., \& Link, A. N. (1988). The entrepreneur: Mainstream views and radical critiques ( $2^{\text {nd }}$ ed.). New York: Praeger.

Hebert, R. F., \& Link, A. N. (1989). In search of the meaning of entrepreneurship. Small Business Economics, 39-49.

Henderson, J. (2002). Building the rural economy with high-growth entrepreneurs. Federal Reserve Bank of Kansas City Economic Review, 87(3), 45-70.

Henricks, M. (2002). Not just a living: The complete guide to creating a business that gives you a life. Cambridge, MA: Perseus.

Hills, G., \& La Forge, R. W. (1992). Marketing and entrepreneurship: the state of art. In D. Sexton, \& J. D. Kasarda (Eds.), The state of the art of entrepreneurship. PWS-Kent Pub. Co.

Hitt, M. A., Ireland, R. D., Camp, S. M., \& Sexton, D. L. (2001). Strategic entrepreneurship: Entrepreneurial strategies for wealth creation. Strategic Management Journal, 22, 479-491.

Ioannides, D., \& Peterson, T. (2003). Tourism 'non-entrepreneurship' in peripheral destinations: A case study of small and medium tourism enterprises on Bornholm, Denmark. Tourism Geographies, 5(4), 408-435.

Ireland, R. D., Hitt, M. A., Camp, S. M., \& Sexton, D. L. (2001). Integrating entrepreneurship and strategic management actions to create firm wealth. The Academy of Management Executive, 15(1), 49-63.

Jennings, P., \& Beaver, G. (1997). The performance and competitive advantage of small firms: A management perspective. International Small Business Journal, 15(2), 63-75. 
Johnson, G., Whittington, R. and Scholes, K. (2011). Exploring Strategy. Harlow, England: Financial Times Prentice Hall.

Kalantaridis , C., \& Bika, Z. (2006). Local embeddedness and rural entrepreneurship: Case study evidence from Cumbria, England. Environment and Planning A, 38, 1561-1579.

Kalleberg, A. L., \& Leicht, K. T. (1991). Gender and organizational performance: Determinants of business survival and success. Academy of Management Journal, 34(1), 136-161.

Kaplan, J. (2003). Patterns of entrepreneurship. Chichester: Wiley.

Kaplan, J. M., \& Warren, A. C. (2010). Patterns of entrepreneurship (2 ${ }^{\text {nd }}$ ed.). Hoboken, N.J: Wiley.

Kidd, N. (2008). Enterprise and productivity: Harnessing competitive forces. New Zealand Treasury Productivity Paper, April 2008.

King, N., \& Horrocks, C. (2010). Interviews in qualitative research. London: SAGE.

Kirzner, I. M. (1978). Competition and Entrepreneurship. University of Chicago Press.

Kirzner, I. (1997). Entrepreneurial discovery and the competitive market process: An Austrian approach. The Journal of Economic Literature, 35, 60-85.

Klapper, L., Amit, R., \& Guillen, M. F. (2010). Entrepreneurship and firm formation across countries. In J. Lerner, \& A. Shoar (Eds.), International differences in entrepreneurship (pp. 129-158). Chicago: University of Chicago Press.

Kuratko, D. F. \& Hodgetts, R. M. (1998). Entrepreneurship, a contemporary approach ( $5^{\text {th }}$ ed.). Fort Worth: Dryden Press.

Kuratko, D. F. \& Hodgetts, R. M. (2004). Entrepreneurship: Theory, process, practice. Mason, Ohio: Thomson/South-Western.

Kuzel, A. (1999). Sampling in qualitative inquiry. In B. Crabtree, \& W. Miller (Eds.), Doing qualitative research ( $2^{\text {nd }}$ ed.) (pp. 33-45). Thousand Oaks, California: Sage. 
Laaksonen, L., Ainamo, A., \& Karjalainen, T. (2011). Entrepreneurial passion: An explorative case study of four metal music ventures. Journal of Research in Marketing and Entrepreneurship, 13(1), 18-36.

Lashley, C. \& Rowson, B. (2010). Lifestyle businesses: Insights into Blackpool's hotel sector. International Journal of Hospitality Management, 29, 511-519.

Lee-Ross, D. (2012). An exploratory study of small accommodation-based tourism firms in Australia. Asia-Pacific Journal of Innovation in Hospitality and Tourism, 1(1), 1-22.

Li, Y., Miao, L., Zhao, X., \& Lehto, X. (2013). When family rooms become guest lounges: Work-family balance of B\&B innkeepers. International Journal of Hospitality Management, 34, 138-149.

Low, M. B. (2001). The adolescence of entrepreneurship research: Specification of purpose. Entrepreneurship Theory and Practice, 25(4), 17-25.

Low, M. B., \& MacMillan, I. C. (1988). Entrepreneurship: Past research and future challenges. Journal of Management, 14(2), 139-161.

Luke, B., Verreynne, M., \& Kearins, K. (2007). Measuring the benefits of entrepreneurship at different levels of analysis. Journal of Management and Organization, 13(4), 312-330.

Macko, A. \& Tyszka, T. (2009). Entrepreneurship and risk taking. Applied Psychology, $58(3), 469-487$.

Mailfert, K. (2007). New farmers and networks: How beginning farmers build social connections in France. Journal of Economic and Social Geography, 98, 2131.

Marchant, B. \& Mottiar, Z. (2011). Understanding lifestyle entrepreneurs and digging beneath the issue of profits: Profiling surf tourism lifestyle entrepreneurs in Ireland. Tourism Planning and Development, 8(2), 171-183. 
Marcketti, S. B., Niehm, L. S., \& Fuloria, R. (2006). An exploratory study of lifestyle entrepreneurship and its relationship to life quality. Family and Consumer Sciences Research Journal, 34(3), 241-259.

Maritz, A., \& Beaver, B. (2006). The New Zealand lifestyle entrepreneur. Regional Frontiers of Entrepreneurship Research, 741-754.

Marks, S. R. \& MacDermid, S. M. (1996). Multiple roles and self: A theory of role balance. Journal of Marriage and the Family, 58, 417-432.

Martinelli, A. (1994). Entrepreneurship and management. In N. J. Smelser, \& R. Swedberg (Eds.), Handbook of economic sociology (pp. 476-503). Princeton: Princeton University Press.

Massey, C. (2005). The size and significance of the small business sector. In C. Massey (Ed.), Entrepreneurship and small business management in New Zealand (pp. 3-16). Auckland, New Zealand: Pearson.

Mattis, M. C. (2004). Women entrepreneurs: out from under the glass ceiling? Women in Management Review, 19(3), 154-163.

McClelland, D. C. (1965). N-achievement and entrepreneurship: A longitudinal study. Journal of Personality and Social Psychology, 1, 389-392.

McClelland, D.C. (1961). The Achieving Society. New York: Feffer \& Simons Inc.

McGhee, N. G. (2012). Interview techniques. In L. Dwyer, A. Gill, \& N. Seetaram (Eds.), Handbook of research methods in tourism: Quantitative and qualitative approaches. UK: Edward Elgar Publishing Ltd.

McGregor, S. L.T., \& Goldsmith, E. B. (1998). Expanding our understanding of quality of life, standard of living, and well-being. Journal of Family and Consumer Sciences, 90(2), 2-6.

Miles, M. B., \& Huberman, A. M. (1994). Qualitative data analysis. Thousand Oaks, CA: Sage. 
Ministry of Economic Development (2011). SMEs in New Zealand: Structure and Dynamics, 2011. Ministry of Economic Development, September 2011. ISSN 1178-3281.

Mitchell, R., \& Hall, M. (2006). Wine tourism research: The state of play. Tourism Review Journal, 9, 307-332.

Morrison, A., Baum, T., \& Andrew, R. (2001). The lifestyle economics of small tourism businesses. Journal of Travel and Tourism Research, 1(1), 16-25.

Morrison, A., Breen, J. \& Ali, S. (2003). Small business growth: Intention, ability, and opportunity. Journal of Small Business Management, 41(4), 417-425.

Morrison, A., Rimmington, M., \& Williams, C. (1999). Entrepreneurship in the Hospitality, Tourism and Leisure Industries. Oxford: Butterworth and Heinemann.

Mottiar, Z. (2007). Lifestyle entrepreneurs and spheres of inter-firm relations: the case of Westport, Co mayo, Ireland. The International Journal of Entrepreneurship and Innovation. 8(1), 67-74.

Muna, F. A., \& Mansour, N. (2009). Balancing work and personal life: the leader as acrobat. Journal of Management Development, 28(2), 121-133.

Murnieks, C. Y., Mosakowski, E., \& Cardon, M. S. (2012). Pathways of passion: Identity, centrality, passion, and behaviour among entrepreneurs. Journal of Management, 1-25.

Narula, V. (2011). Trees - a metaphor for entrepreneurship, Retrieved on 15/08/2013 from http://www.keyhubs.com/blog/trees-a-metaphor-for-entrepreneurship/.

New Zealand Ministry of Economic Development. (2001). SME's in New Zealand: Structure and dynamics. Wellington, New Zealand: New Zealand Government.

O'Leary, Z. (2004). The essential guide to doing research. London: Sage Publications Inc. 
Ogbor, J. O. (2000). Mythicizing and reification in entrepreneurial discourse: Ideology critique of entrepreneurial studies. Journal of Management Studies, 37, 605635.

Patton, M. Q. (2002). Qualitative research and evaluation methods ( $3^{\text {rd }} \mathrm{ed}$.). Thousand Oaks, Cali: Sage Publication.

Peters, M., Frehse, J., \& Buhalis, D. (2009). The importance of lifestyle entrepreneurship: A conceptual study of the tourism industry. PASOS, 7(2), 393-405.

Porter, M. E. (1980). Competitive Strategy: Techniques for analysing Industries and Competitors. New York, USA: The Free Press.

Poutziouris, P. (2003). The strategic orientation of owner-managers of small ventures: Evidence from the UK small business economy. International Journal of Entrepreneurial Behaviour and Research, 9(5), 185-214.

Puri, M., \& Robinson, D. T. (2013). The economic psychology of entrepreneurship and family business. Journal of Economics and Management Strategy, 22(1), 423-444.

Rehman, S., \& Roomi, M. A. (2012). Gender and work-life balance: A phenomenological study of women entrepreneurs in Pakistan. Journal of Small Business and Enterprise Development, 19(2), 209-228.

Reynolds, P. D., Carter, N. M., Gartner, W.B., \& Greene, P.G. (2004). The prevalence of nascent entrepreneurs in the United States: Evidence from the panel study of entrepreneurial dynamics. Small Business Economics, 23, 263-284.

Rimmington, M., Morrisson, A., \& Williams, C. (1999). Entrepreneurship in the hospitality, tourism and leisure industries. Oxford: Butterworth-Heinemann:

Rountree, K., \& Liang, P. (1996). Writing by degrees: A practical guide to writing theses and research papers. Auckland: Longman.

Rouse, M. (2011). Lifestyle business, Retrieved on 02/10/2013 from http://whatis.techtarget.com/definition/lifestyle-business. 
Saunders, M., Lewis, P., \& Thornhill, A. (2009). Research methods for business students. Harlow, England: Prentice Hall.

Schumpeter, J. A. (1947). The creative response in economic history. Journal of Economic History, 7, 149-159.

Schumpeter, J. A., \& Opie, R. (1934). The theory of economic development: An inquiry into profits, capital, credit, interest, and the business cycle. Cambridge, Mass: Harvard University Press.

Schutjens, V. A., \& Wever, E. (2000). Determinants of new firm success. Papers in Regional Science, 79(2), 135-159.

Scott Morton, F. M., \& Podolny, J. M. (2002). Love or money? The effects of owner motivation in the California wine industry. The Journal of Industrial Economics, 50(4), 431-456.

Segal, G., Borgia, D., \& Schoenfeld, J. (2005). The motivation to become an entrepreneur. Journal of Entrepreneurial Behaviour and Research, 11(1), 4257.

Shane, S. \& Venkataraman, S. (2000). The promise of entrepreneurship as a field of research. Academy of Management Review, 25(1), 217-226.

Shane, S., Locke, E. A., \& Collins, C. J. (2003). Entrepreneurial motivation. Human Resource Management Review, 13, 257-279.

Sharma, P., Chrisman, J. J., \& Chua, J. H. (1997). Strategic management of the family business: Past research and future challenges. Family Business Review, 10(1), $1-35$.

Shaw, G., \& Williams, A. M. (1987). Firm formation and operating characteristics in the Cornish tourist industry - the case of Looe. Tourism Management, 8(4), 344-348. 
Shaw, G., \& Williams, A. M. (2004). From Lifestyle Consumption to Lifestyle Production: Changing patterns of tourism entrepreneurship. In R. Thomas (Ed.), Small firms in tourism: International perspectives (pp. 100-113). Amsterdam: Elsevier.

Sisson, N. (n. d.). Strategies for achieving a better work-life balance, Retrieved on 25/11/2013 from http://sbh.hotfrog.co.nz/topics/work-lifebalance/strategies-for-achieving-a-better-work-life-balanc.

Smilor, R. W. (1997). Entrepreneurship: Reflections on a subversive activity. Journal of Business Venturing, 12, 341-346.

Smith, C. R. (2000). Managing work and family in small "copreneurial" business: an Australian study. Women in Management Review, 15(5/6), 283-289.

Snape, D., \& Spencer, L. (2003). The foundations of qualitative research. In J. Ritchie, \& J. Lewis (Eds.), Qualitative research practice: A guide for social science students and researchers. London: SAGE Publications Ltd.

Stam, E. (2007). Why butterflies don't leave: Locational behaviour of entrepreneurial firms. Economic Geography, 83(1), 27-50.

Statistics New Zealand (2012). New Zealand Business Demography Statistics: At February 2012, Statistics New Zealand, October 2012, ISSN 1174-1988.

Sternberg, R. S. (2004). Successful intelligence as a basis for entrepreneurship. Journal of Business Venturing, 19, 189-201.

Stewart, W. H., Watson, W. E., Carland, J. C., \& Carland, J. W. (1988). A proclivity for entrepreneurship: A comparison of entrepreneurs, small business owners, and corporate managers. Journal of Business Venturing, 14, 189-214.

Still, L. V., \& Walker, E. A. (2006). The self-employed woman and her business: A profile. Women in Management Review, 21(4), 294-310.

Stone, I., \& Stubbs, C. (2007). Enterprising expatriates: Lifestyle migration and entrepreneurship in rural southern Europe. Entrepreneurship and Regional Development: An International Journal, 19(5), 433-450. 
Szivas, E. (2001). Entrance into tourism entrepreneurship: A UK case study. Tourism and Hospitality Research, 3(2), 163-172.

Thomas, R., Friel, M., Jameson, S., \& Parsons, D. (1997). The national survey of small tourism and hospitality firms: Annual report 1996-1997. Leeds: Centre for the Study of Small Tourism and Hospitality firms, Metropolitan University.

Thompson, K. D. (1990). Married ... with business. Black Enterprise, 47-54.

Thornton, P. H. (1999). The sociology of entrepreneurship. Annual Review of Sociology, 25, 19-46.

Timmons, J. A. (1992). New venture creation: Entrepreneurship in the 1990's. Homewood, IL: Irwin.

Timmons, J. A., \& Spinelli, S. (2004). New venture creation: Entrepreneurship for the $21^{\text {st }}$ century $\left(6^{\text {th }}\right.$ ed.). Boston, Mass: McGraw-Hill.

Ucbasaran, D., Westhead, P., \& Wright, M. (2001). The focus of entrepreneurial research: Contextual and process issues. Entrepreneurship and Practice, 25(4), 57-80.

Vallerand, R. J., Blanchard, C., Mageau, G. A., Koestner, R., Ratelle, C., Leonard, M., Gagné, M., \& Marsolais, J, (2003). Les passions de l'âme: On obsessive and harmonious passion. Journal of Personality and Social Psychology, 85, 756767.

Walker, E., \& Brown, A. (2004). What success factors are important to small business owners? International Small Business Journal, 22(6), 577-594.

Webster, F. A. (1977). Entrepreneurs and ventures: An attempt at classification and clarification. The Academy of Management Review, 2(1), 54-61.

Wennekers, S., \& Thurik, R. (1999). Linking entrepreneurship and economic growth. Small Business Economics, 13, 27-55. 
Wiklund, J., Davidsson, P., \& Delmar, F. (2003). What do they think and feel about growth: An expectancy-value approach to small business managers' attitudes toward growth. Entrepreneurship Theory and Practice, 20, 247-270.

Williams, A. M., Shaw, G., \& Greewood, J. (1989). From tourist to tourism entrepreneur, from consumption to production: Evidence from Cornwall, England. Environment and Planning A, 21, 1639-1653.

Woods, C., Dale, C., Shepherd, D., \& Oliver, L. (2005). Family firms and selfemployment. In C. Massey (Ed.), Entrepreneurship and small business management in New Zealand (pp. 270-281). Auckland, N.Z: Pearson Prentice.

Wu, S., Matthews, L., \& Dagher, G. K. (2007). Need for achievement, business goals, and entrepreneurial persistence. Management Research News, 30(12), 928941.

Xavier, S. R., Kelley, D., Kew, J., Herrington, M., \& Vorderwulbecke, A. (2012). Global entrepreneurship monitor 2012 global report. Global Entrepreneurship Research Association (GERA).

Zhao, H., \& Seibert, S. E. (2006). The big five personality dimensions and entrepreneurial status: a meta-analytical review. Journal of Applied Psychology, 91(2), 259-271. 


\title{
Appendix A: Information Sheet Generating Profits out of Passion: A study of New Zealand Wineries
}

\author{
Dear Sir/Madam,
}

I am a Masters student at Victoria University of Wellington, doing a research project on entrepreneurship in New Zealand wineries. My research looks at family owned and operated wineries that have attained success in this industry by generating profits out of their passion. The aim of my study is to develop an understanding of issues such as motivations, goals, objectives and other dilemmas that you have faced, as well as the strategies that were used in balancing these different aspects. Your winery has been identified as one that would be particularly appropriate for my research and I believe you are in a position to provide me with unique insights into the challenges noted above.

I would like to request your contribution to the study by participating in an interview. The interview will take approximately 60 minutes and will be scheduled at a time and place that suits you. An outline of the questions will be sent to you prior to the interview. With your permission, the interview will be digitally recorded. Ethical approval from Victoria University of Wellington has been obtained for the purposes of this research. Your participation is entirely voluntary and you would be free to withdraw the information you provide at any stage prior to $1^{\text {st }}$ March 2013 when analysis of all data is likely to be completed.

The analysis from the interviews will be reported in an aggregated, non-attributable form. All responses will be treated with complete confidentiality and neither your name nor your organization's will appear in the results reported. All data collected for this study will be stored securely, prior to their destruction within two years of the completion of this research. If you would like to receive a summary of final results, this will be provided to you by email or post after all data analysis has been completed.

Thank you in advance for your time and consideration.

If you have any questions about the study, or if you would like to receive more information, please do not hesitate to contact either of those listed below. We are happy to answer your questions.

\section{Researcher}

Juhie Sugand

School of Management

Victoria University of Wellington

Mobile: 0220744094

Email: juhie.sugand@vuw.ac.nz

\author{
Supervisor \\ Associate Prof. Urs Daellenbach \\ School of Management \\ Victoria University of Management \\ Phone: 044635732 \\ Email: urs.daellenbach@vuw.ac.nz
}




\section{Appendix B: Research Consent Form}

\section{Generating Profits out of Passion: A study of New Zealand Wineries}

This consent form ensures that you have been sufficiently informed about the purpose of the research, outlining your rights as a participant in the study entitled 'Generating Profits out of Passion: A study of New Zealand Wineries' conducted by Juhie Sugand.

- I have been provided with adequate information relating to the nature and objectives of this research project and have been given contact details with which to seek further clarification or explanation.

- My participation is entirely voluntary and I agree to be interviewed for the purpose of the study, with the understanding that I have the right to decline to answer any question asked.

- I understand that the interview may, with my permission be recorded, and the sound files will be erased upon completion of the research.

- I understand that I may withdraw from this study at any time before $1^{\text {st }}$ May 2013 without providing reasons for my withdrawal. In such case, all of the information that I provided will be destroyed by the researcher.

- I understand that any information or opinions that I provide will be kept confidential and reported only in such a form that neither you nor your organization will be identifiable.

- I understand that Juhie Sugand is conducting this study for completion of her Masters thesis. The final thesis will be submitted for grading and versions of it may possibly appear as journal publications or presented at academic or professional conferences. Any further use will require my consent.

I agree to participate in the study

I give consent for the interview to be audio recorded

I would like to receive a copy of the final summary of results

Email:

Postal address:

Signed:

Name of Interviewee:

Date: 


\section{Appendix C: Interview Outline}

\section{Research Project:}

\section{Generating Profits out of Passion: A study of New Zealand Wineries}

- How long have you been in this business?

- What is the company's employment structure? - number of part-time and full-time employees, seasonal employment, family in business

- What are your goals and objectives for this business?

- What got you interested in this industry?

Do you have previous education/experience in this field?

- What are your motivations to run this business?

What were your motivations during start-up?

$>$ What non-financial objectives are important to your business?

- Do you perceive any trade-offs between different business objectives?

- Who are your target customers?

- What are your views on business growth?

- Is there any conflict between growth and other business objectives?

- According to you, what is a successful business?

- What challenges have you faced since starting the business?

Do characteristics of the wine industry have any effect?

- What key strategies have you used to address these challenges?

- What are your future plans for the business?

- How will you accomplish this?

- Further comments 